Issued by Sandia National Laboratories, operated for the United States Department of Energy by Sandia Corporation.

NOTICE: This report was prepared as an account of work sponsored by an agency of the United States Government. Neither the United States Government, nor any agency thereof, nor any of their employees, nor any of their contractors, subcontractors, or their employees, make any warranty, express or implied, or assume any legal liability or responsibility for the accuracy, completeness, or usefulness of any information, apparatus, product, or process disclosed, or represent that its use would not infringe privately owned rights. Reference herein to any specific commercial product, process, or service by trade name, trademark, manufacturer, or otherwise, does not necessarily constitute or imply its endorsement, recommendation, or favoring by the United States Government, any agency thereof, or any of their contractors or subcontractors. The views and opinions expressed herein do not necessarily state or reflect those of the United States Government, any agency thereof, or any of their contractors.

Printed in the United States of America. This report has been reproduced directly from the best available copy.

Available to DOE and DOE contractors from

Office of Scientific and Technical Information

P.O. Box 62

Oak Ridge, TN 37831

Prices available from (703) 605-6000

Web site: http:/www.ntis.gov/ordering.htm

Available to the public from

National Technical Information Service

U.S. Department of Commerce

5285 Port Royal Rd

Springfield, VA 22161

NTIS price codes

Printed copy: A05

Microfiche copy: A01

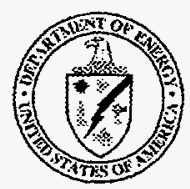




\section{DISCLAIMER}

Portions of this document may be illegible in electronic image products. Images are produced from the best available original document. 
SAND 99-1047

Unlimited Release

Printed May 1999

\title{
Thermochemical Analysis for Purification of Polysilicon Melts
}

\author{
Pauline Ho \\ Chemical Processing Science Department \\ James M. Gee \\ PV System Components Department \\ Sandia National Laboratories \\ P.O. Box 5800 \\ Albuquerque, NM 87085-0601
}

\begin{abstract}
Chemical equilibrium calculations are presented that are relevant to the purification of molten silicon by gas-blowing. The equilibrium distributions of silicon, boron, phosphorus carbon and iron among the solid, liquid and gas phases are reported for a variety of added chemicals, temperatures and total pressures. The identities of the dominant chemical species for each element in each phase are also provided for these conditions. The added gases examined are $\mathrm{O}_{2}$, air, water, wet air, $\mathrm{HCl}, \mathrm{Cl}_{2}, \mathrm{Cl}_{2} / \mathrm{O}_{2}, \mathrm{SiCl}_{4}, \mathrm{NH}_{3}, \mathrm{NH}_{4} \mathrm{OH}$, and $\mathrm{NH}_{4} \mathrm{Cl}$. These calculations suggest possible purification schemes, although kinetic or transport limitations may prove to be significant.
\end{abstract}




\section{Acknowledgments}

The authors acknowledge the expertise of Dr. Frank Zanner and his role in getting this project started. We also thank Drs. James Van den Avyle, James Stepanek, and James P. Maroone for helpful technical discussions of the experimental work.

This work was funded by Sandia National Laboratories' Laboratory Directed Research and Development (LDRD) Program as part of a project entitled "Solar-Grade Polysilicon Development". 


\section{Table of Contents}

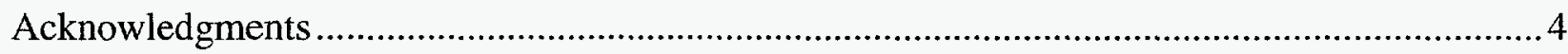

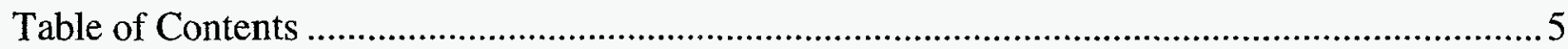

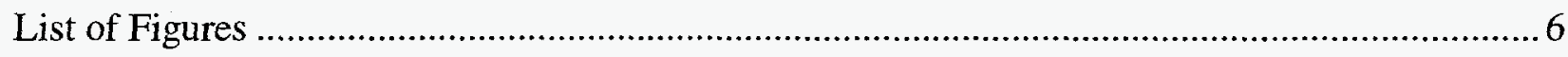

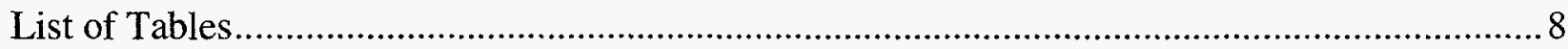

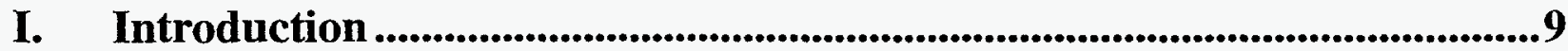

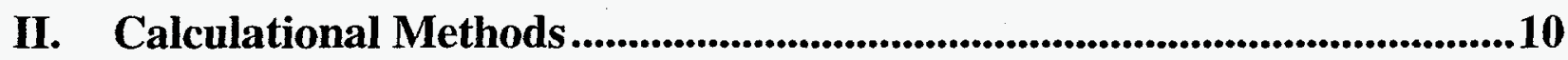

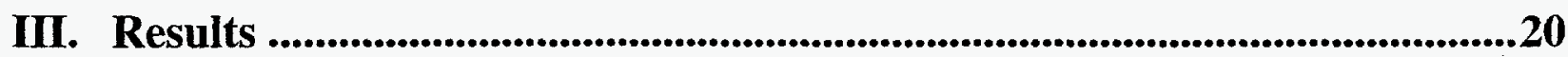

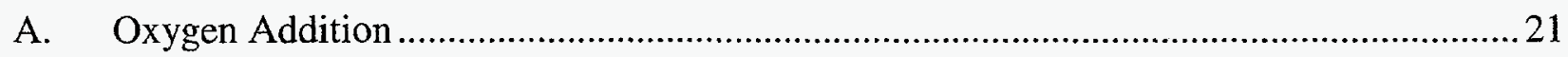

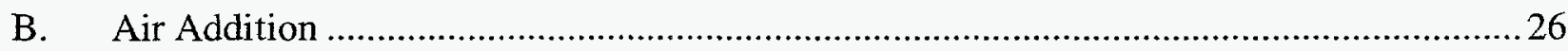

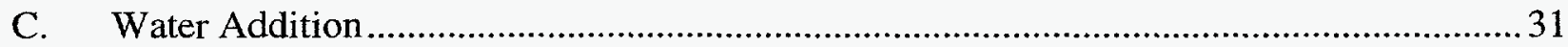

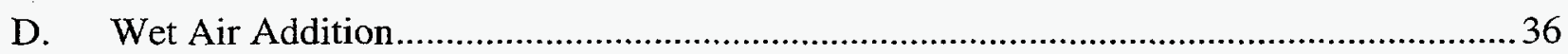

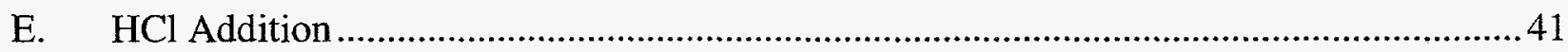

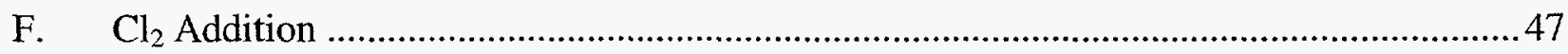

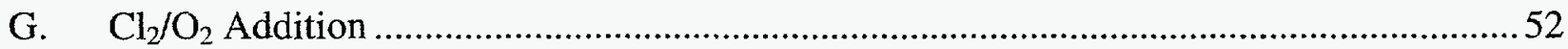

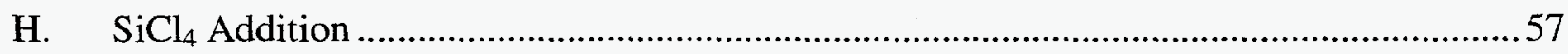

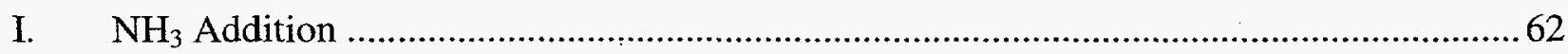

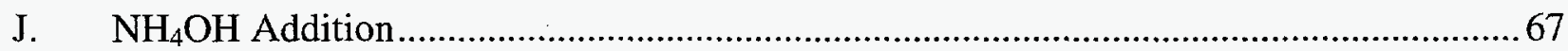

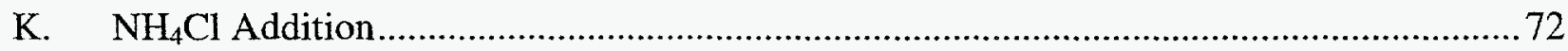

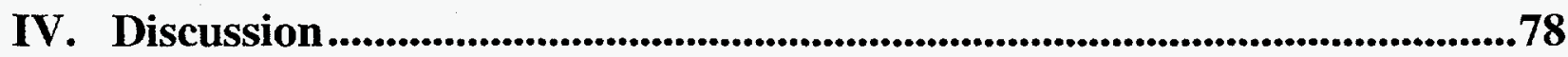

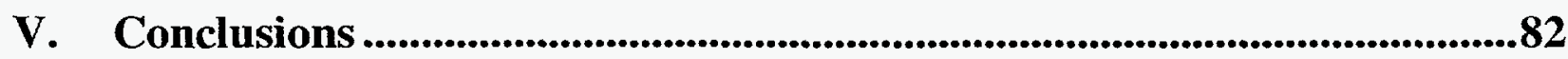

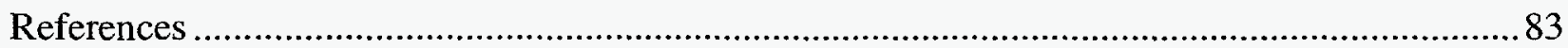

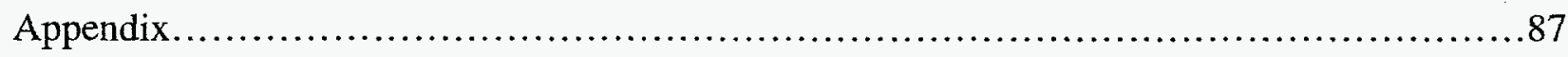




\section{List of Figures}

Figure 1. Distribution of elements among phases: $\mathrm{O}_{2}=0.05, \mathrm{Ar}=0.01,1450^{\circ} \mathrm{C} \ldots \ldots \ldots \ldots \ldots . .22$

Figure 2. Distribution of elements among phases: $\mathrm{O}_{2}=0.05, \mathrm{Ar}=0.01,1550^{\circ} \mathrm{C} \ldots \ldots \ldots \ldots \ldots \ldots .23$

Figure 3. Distribution of elements among phases: $\mathrm{O}_{2} \doteq 0.05, \mathrm{Ar}=0.01,1650^{\circ} \mathrm{C} \ldots \ldots \ldots \ldots \ldots \ldots . \ldots \ldots$

Figure 4. Distribution of elements among phases: $\mathrm{O}_{2}=0.01, \mathrm{~N}_{2}=0.04, \mathrm{Ar}=0.01,1450^{\circ} \mathrm{C} \ldots .27$

Figure 5. Distribution of elements among phases: $\mathrm{O}_{2}=0.01, \mathrm{~N}_{2}=0.04, \mathrm{Ar}=0.01,1550^{\circ} \mathrm{C} \ldots . .28$

Figure 6. Distribution of elements among phases: $\mathrm{O}_{2}=0.01, \mathrm{~N}_{2}=0.04, \mathrm{Ar}=0.01,1650^{\circ} \mathrm{C} \ldots .29$

Figure 7. Distribution of elements among phases: $\mathrm{H}_{2} \mathrm{O}=0.05, \mathrm{Ar}=0.01,1450^{\circ} \mathrm{C} \ldots \ldots \ldots \ldots . .32$

Figure 8. Distribution of elements among phases: $\mathrm{H}_{2} \mathrm{O}=0.05, \mathrm{Ar}=0.01,1550^{\circ} \mathrm{C} \ldots \ldots \ldots \ldots \ldots . . . \ldots 33$

Figure 9. Distribution of elements among phases: $\mathrm{H}_{2} \mathrm{O}=0.05, \mathrm{Ar}=0.01,1650^{\circ} \mathrm{C} \ldots \ldots \ldots \ldots \ldots . . \ldots 34$

Figure 10. Distribution of elements among phases: $\mathrm{H}_{2} \mathrm{O}=0.01, \mathrm{O}_{2}=0.008, \mathrm{~N}_{2}=0.032, \mathrm{Ar}=$ $0.01,1450^{\circ} \mathrm{C}$

Figure 11. Distribution of elements among phases: $\mathrm{H}_{2} \mathrm{O}=0.01, \mathrm{O}_{2}=0.008, \mathrm{~N}_{2}=0.032, \mathrm{Ar}=$ $0.01,1550^{\circ} \mathrm{C}$

Figure 12. Distribution of elements among phases: $\mathrm{H}_{2} \mathrm{O}=0.01, \mathrm{O}_{2}=0.008, \mathrm{~N}_{2}=0.032, \mathrm{Ar}=$ $0.01,1650^{\circ} \mathrm{C}$

Figure 13. Distribution of elements among phases: $\mathrm{HCl}=0.05, \mathrm{Ar}=0.01,1450^{\circ} \mathrm{C}$ 42

Figure 14. Distribution of elements among phases: $\mathrm{HCl}=0.05, \mathrm{Ar}=0.01,1550^{\circ} \mathrm{C}$. 43

Figure 15. Distribution of elements among phases: $\mathrm{HCl}=0.05, \mathrm{Ar}=0.01,1650^{\circ} \mathrm{C} \ldots \ldots \ldots \ldots . .44$

Figure 16. Distribution of elements among phases: $\mathrm{Cl}_{2}=0.05, \mathrm{Ar}=0.01,1450^{\circ} \mathrm{C} \ldots \ldots \ldots \ldots \ldots 48$

Figure 17. Distribution of elements among phases: $\mathrm{Cl}_{2}=0.05, \mathrm{Ar}=0.01,1550^{\circ} \mathrm{C} \ldots \ldots \ldots \ldots \ldots . . . .49$

Figure 18. Distribution of elements among phases: $\mathrm{Cl}_{2}=0.05, \mathrm{Ar}=0.01,1650^{\circ} \mathrm{C}$ 50

Figure 19. Distribution of elements among phases: $\mathrm{Cl}_{2}=0.025, \mathrm{O}_{2}=0.025, \mathrm{Ar}=0.01,1450^{\circ} \mathrm{C}$.

Figure 20. Distribution of elements among phases: $\mathrm{Cl}_{2}=0.025, \mathrm{O}_{2}=0.025, \mathrm{Ar}=0.01,1550^{\circ} \mathrm{C}$.

Figure 21. Distribution of elements among phases: $\mathrm{Cl}_{2}=0.025, \mathrm{O}_{2}=0.025, \mathrm{Ar}=0.01,1650^{\circ} \mathrm{C}$.

Figure 22. Distribution of elements among phases: $\mathrm{SiCl}_{4}=0.05, \mathrm{Ar}=0.01,1450^{\circ} \mathrm{C}$. 58 
Figure 23. Distribution of elements among phases: $\mathrm{SiCl}_{4}=0.05, \mathrm{Ar}=0.01,1550^{\circ} \mathrm{C} \ldots \ldots \ldots \ldots . . . .59$

Figure 24. Distribution of elements among phases: $\mathrm{SiCl}_{4}=0.05, \mathrm{Ar}=0.01,1650^{\circ} \mathrm{C} \ldots \ldots \ldots \ldots .60$

Figure 25. Distribution of elements among phases: $\mathrm{NH}_{3}=0.05, \mathrm{Ar}=0.01,1450^{\circ} \mathrm{C} \ldots \ldots \ldots \ldots . .63$

Figure 26. Distribution of elements among phases: $\mathrm{NH}_{3}=0.05, \mathrm{Ar}=0.01,1550^{\circ} \mathrm{C} \ldots \ldots \ldots \ldots . . .64$

Figure 27. Distribution of elements among phases: $\mathrm{NH}_{3}=0.05, \mathrm{Ar}=0.01,1650^{\circ} \mathrm{C} \ldots \ldots \ldots \ldots . . .65$

Figure 28. Distribution of elements among phases: $\mathrm{NH}_{3}=0.015, \mathrm{H}_{2} \mathrm{O}=0.035, \mathrm{Ar}=0.01$, $1450^{\circ} \mathrm{C}$

Figure 29. Distribution of elements among phases: $\mathrm{NH}_{3}=0.015, \mathrm{H}_{2} \mathrm{O}=0.035, \mathrm{Ar}=0.01$, $1550^{\circ} \mathrm{C}$

Figure 30. Distribution of elements among phases: $\mathrm{NH}_{3}=0.015, \mathrm{H}_{2} \mathrm{O}=0.035, \mathrm{Ar}=0.01$, $1650^{\circ} \mathrm{C}$ 70

Figure 31. Distribution of elements among phases: $\mathrm{NH}_{4} \mathrm{Cl}=0.05, \mathrm{Ar}=0.01,1450^{\circ} \mathrm{C}$ 73

Figure 32. Distribution of elements among phases: $\mathrm{NH}_{4} \mathrm{Cl}=0.05, \mathrm{Ar}=0.01,1550^{\circ} \mathrm{C}$ 74

Figure 33. Distribution of elements among phases: $\mathrm{NH}_{4} \mathrm{Cl}=0.05, \mathrm{Ar}=0.01,1650^{\circ} \mathrm{C}$ 75 


\section{List of Tables}

Table 1. Chemical species considered in equilibrium calculations...........................................12

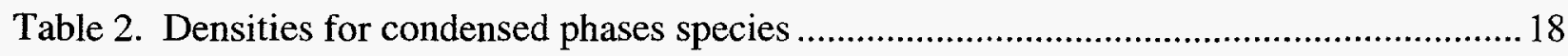

Table 3. Chemical species actually used in equilibrium calculations........................................19

Table 4. Dominant* chemical species for silicon and impurities with $\mathrm{O}_{2} / \mathrm{Ar}$ addition................25

Table 5. Dominant* chemical species for silicon and impurities with $\mathrm{O}_{2} / \mathrm{N}_{2} / \mathrm{Ar}$ addition. .......... 30

Table 6. Dominant* chemical species for silicon and impurities with $\mathrm{H}_{2} \mathrm{O} / \mathrm{Ar}$ addition...............35

Table 7. Dominant* chemical species for silicon and impurities with $\mathrm{H}_{2} \mathrm{O} / \mathrm{O}_{2} / \mathrm{N}_{2} / \mathrm{Ar}$ addition. . 40

Table 8. Dominant* chemical species for silicon and impurities with $\mathrm{HCl} / \mathrm{Ar}$ addition. .............45

Table 9. Dominant* chemical species for silicon and impurities with $\mathrm{Cl}_{2} / \mathrm{Ar}$ addition.................51

Table 10. Dominant* chemical species for silicon and impurities with $\mathrm{Cl}_{2} / \mathrm{O}_{2} / \mathrm{Ar}$ addition. .......56

Table 11. Dominant* chemical species for silicon and impurities with $\mathrm{SiCl}_{4} / \mathrm{Ar}$ addition. .........61

Table 12. Dominant* chemical species for silicon and impurities with $\mathrm{NH}_{3} / \mathrm{Ar}$ addition............66

Table 13. Dominant* chemical species for silicon and impurities with $\mathrm{NH}_{3} / \mathrm{H}_{2} \mathrm{O} / \mathrm{Ar}$ addition... 71

Table 14. Dominant* chemical species for silicon and impurities with $\mathrm{NH}_{4} \mathrm{Cl} / \mathrm{Ar}$ addition........76 


\section{Thermochemical Analysis for Purification of Polysilicon Melts}

\section{Introduction}

The availability of polysilicon feedstock has become a major issue for the photovoltaic (PV) industry in recent years. Most of the current polysilicon feedstock is derived from rejected material from the semiconductor industry. However, during expansions in the integrated-circuit industry, the reject material became rare and more expensive [1]. Although economic downturns in the integrated-circuit industry periodically increase the availability of the reject material to the PV industry, the continued rapid expansion of the PV crystalline-silicon industry will eventually require a dedicated supply of polysilicon feedstock.

The photovoltaic industry can accept a lower purity polysilicon feedstock ("solar-grade") compared to the semiconductor industry. The purity requirements and potential production techniques for solar-grade polysilicon have been reviewed [2]. One interesting process from previous research involves reactive gas blowing of the molten silicon charge. In early work, Dosaj, et al. reported a reduction of metal and boron impurities from silicon melts using reactive gas blowing with $\mathrm{O}_{2}$ and $\mathrm{Cl}_{2}$ [3]. The same authors later reassessed their data and the literature, and concluded that $\mathrm{Cl}_{2}$ and $\mathrm{O}_{2} / \mathrm{Cl}_{2}$ gas blowing are only effective for removing $\mathrm{Al}, \mathrm{Ca}$, and $\mathrm{Mg}$ from the silicon melt [4]. Khattak and Schmid [5] have reported that the combination of vacuum, slagging, moist argon blowing and directional solidification reduced impurity levels, including B and P. More recently, researchers from Kawasaki Steel Corp. reported removal of B and $\mathrm{C}$ from silicon melts using reactive gas blowing with an $\mathrm{O}_{2} / \mathrm{Ar}$ plasma torch [6]. Processes that purify the silicon melt are believed to be potentially much lower cost compared to present production methods that purify gas species.

In this report, we describe chemical equilibrium calculations relevant to the removal of $\mathrm{C}, \mathrm{B}, \mathrm{P}$ and Fe from silicon melts. The purpose of the calculations is to help guide experimental investigations that will be described elsewhere, and to understand the purification process. Preliminary results from these calculations have been presented elsewhere[7], as well as similar work by other researchers [8]. This type of analysis provides information as to which chemical 
species are likely to form when various gases are blown over molten silicon. If these species are gases, they could be pumped out of the system during the blowing process. If these species are solid, they might be separable from the liquid or solid silicon, depending on the relative densities. These calculations are fairly limited in that they only examine the effects of thermochemistry on the composition of the system as a function of total pressure and temperature. The assumption of chemical equilibrium means that relative rate effects are ignored and complete mixing takes place. Kinetic or mass transport effects will only decrease the amount of a reaction product relative to the results presented here.

\section{Calculational Methods}

These studies used the code EQUIL [9], which is part of the CHEMKIN Collection of software[10], and is a CHEMKIN implementation of STANJAN [11]. This code uses a minimization-of-free-energy method to determine the equilibrium composition of the mixture. This method for determining chemical equilibrium treats all possible reactions between all chemical species included in the calculation, in contrast with other methods which involve specifying a set of reactions between a limited set of chemical species. Through Surface Chemkin, EQUIL can handle multiple phases, including condensed phases. Each phase can contain multiple species, but they are treated ideally. Although treating the gas-phase as ideal is a fairly good approximation, this will be less true for the condensed phases. Treating these systems as ideal is quite common in these sorts of calculations, and generally results from a lack of data about non-ideal effects. The approach taken here, however, should be adequate for the present purpose of screening possible chemical systems for silicon purification.

A standard starting mixture was chosen for these calculations based on information on the composition of metallurgical-grade silicon of interest. For 1 mole of silicon, levels for each of the impurities of most interest were set for carbon at the $1000 \mathrm{ppm}$ level, boron and phosphorus at the $2.5 \mathrm{ppm}$ level, and iron at the $1000 \mathrm{ppm}$ level. To evaluate the effects of blowing gas over the molten silicon, various reactants were included in the calculation, generally at the 0.05 mole level. This represents a substantial gas exposure, as it corresponds to blowing 5 SLM of gas for 80 minutes over a $10 \mathrm{~kg}$ sample of silicon. Argon was also included in the equilibrium 
calculations at the 0.01 mole level to ensure that there would always be some gas present. [If the input gas reacts to form solid products, the absence of gaseous species can cause numerical problems in the calculations. A constant pressure and temperature is specified, so the loss of gas leads to an extremely small volume in the simulation, which in turn can cause convergence problems.]

Although the various "blowing gas" additions are discussed in terms of specific chemical species being input (i.e. water or $\mathrm{O}_{2}$ ), the equilibrium analysis is actually only dependent on the ratios of the different elements that are input into the system. In other words, the composition of the system at equilibrium will be the same if one mole of water is specified in the input file or one mole of $\mathrm{H}_{2}$ plus half a mole of $\mathrm{O}_{2}$ is specified in the input file. Kinetically, there may be a large difference, and the amount of heat released when these gases react with silicon can be quite different, but the chemical composition at equilibrium is the same.

For a specified input gas mixture, the equilibrium composition of the system was calculated for a range of pressures and temperatures. The furnace system to be used for the experiments is vacuum capable, so pressures of 0.001 to 1 atm were investigated. Silicon melts at $1410^{\circ} \mathrm{C}$ $(1683 \mathrm{~K})$ and the various forms of silicon dioxide in the range of $1610^{\circ} \mathrm{C}$ to $1703^{\circ} \mathrm{C}(1883 \mathrm{~K}$ to $1976 \mathrm{~K}$ ), so results at temperatures of 1450,1550 , and $1650^{\circ} \mathrm{C}$ are reported in this study. The distribution of the impurity elements among the solid, liquid and gas phases should correlate with the likelihood of being able to remove the impurity either by pumping away gaseous byproducts, or separation of solids from the liquid silicon.

Table 1 lists the chemical species considered in these calculations, along with the source of the thermochemical data used. In general, a species was considered if it was composed of the relevant elements and thermochemical data for that species was straightforwardly accessible in the polynomial-fit format used by CHEMKIN. More gas-phase species than condensed phase species were considered, primarily because of the availability of data. 


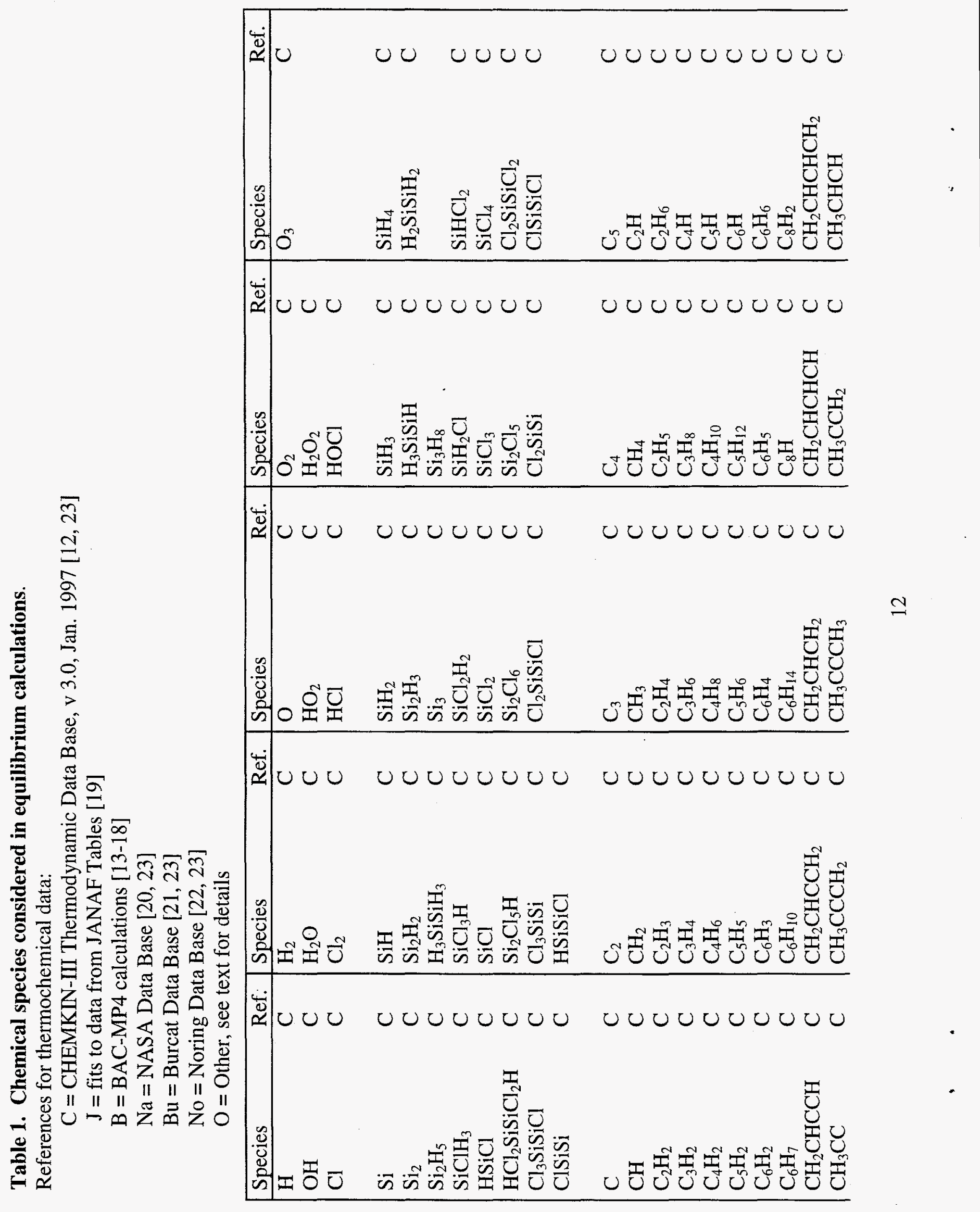




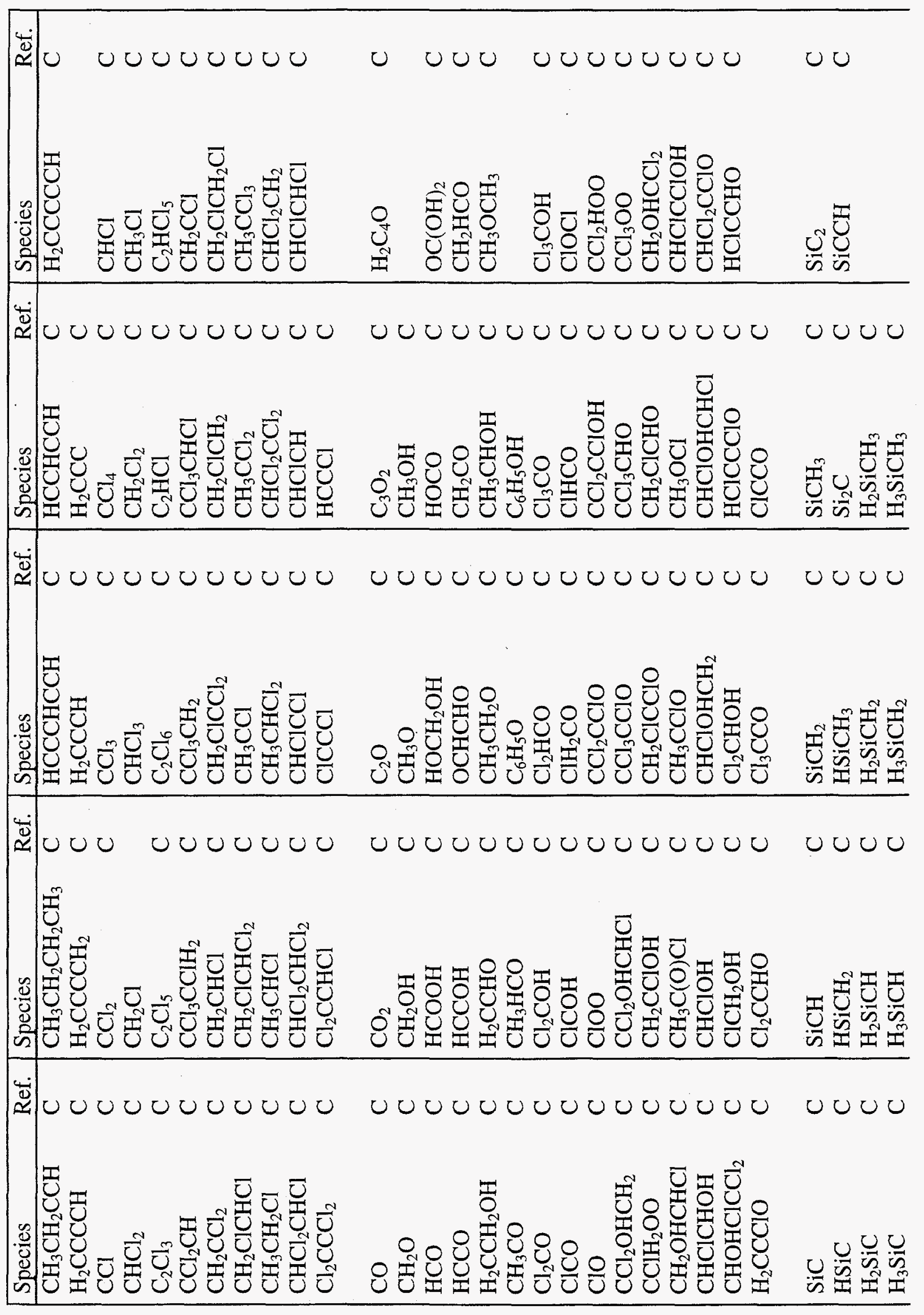


$\dot{4}$

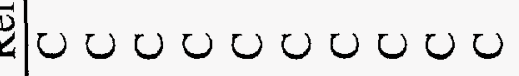

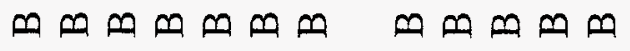

$\circlearrowright \cup U$

胥

需罢

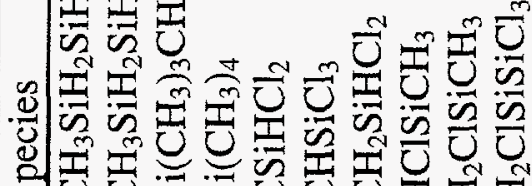

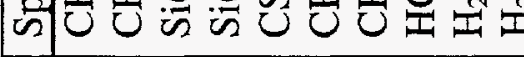

$\stackrel{\dot{m}}{\alpha}$

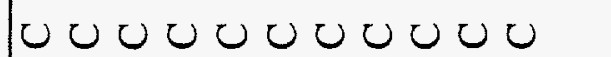

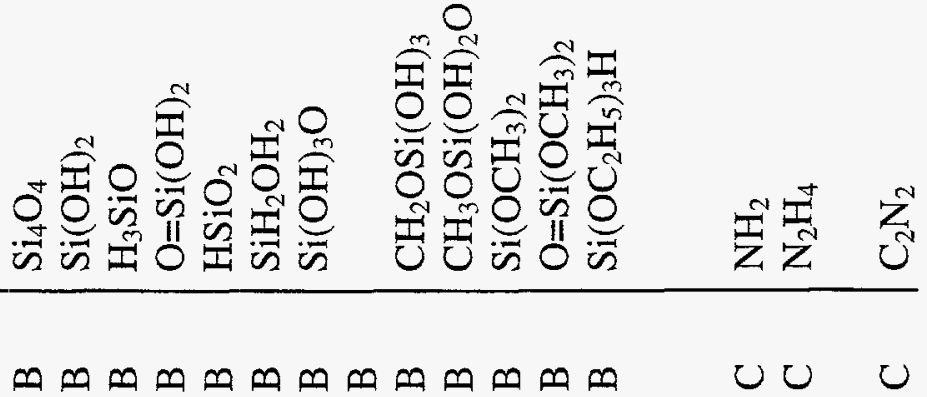

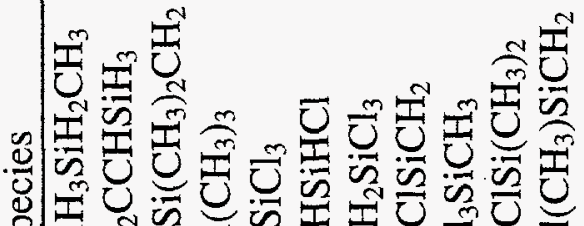

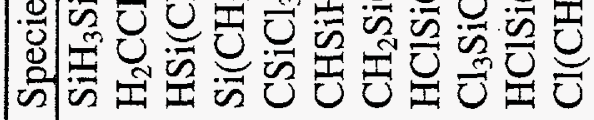

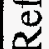

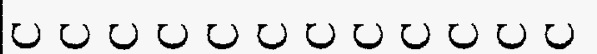

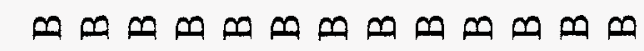

$\cup \cup \cup$

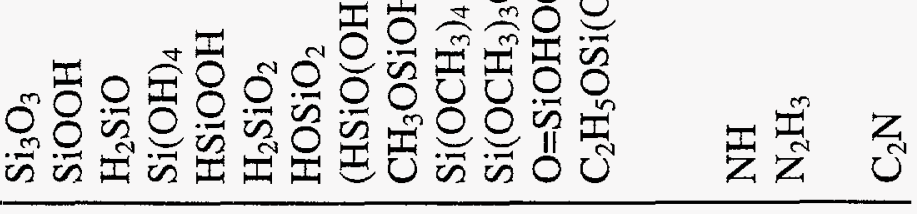

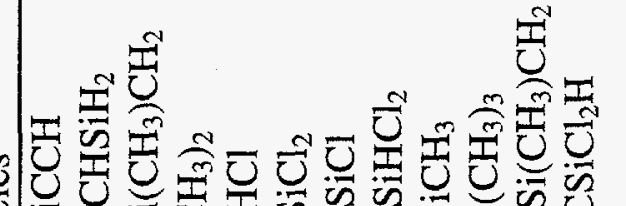

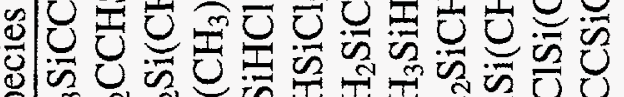

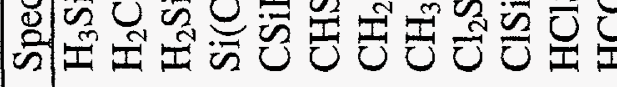

$\frac{\dot{m}}{\sim}$

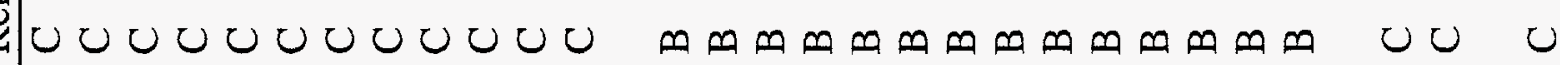

工㞼

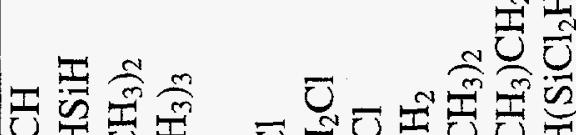

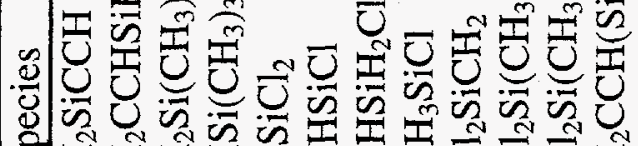

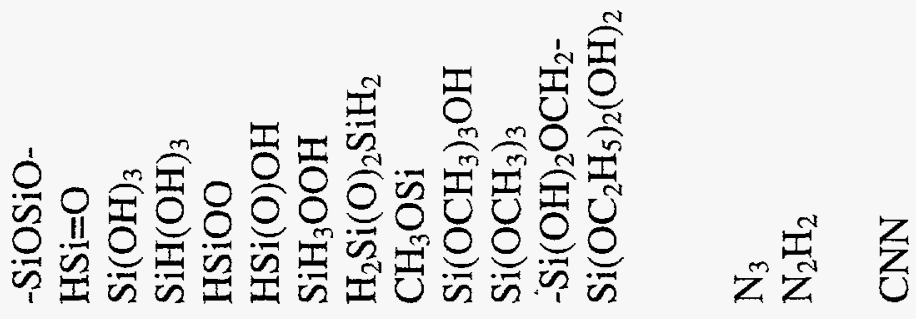

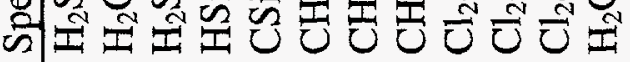

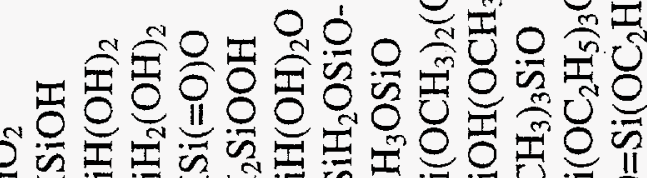

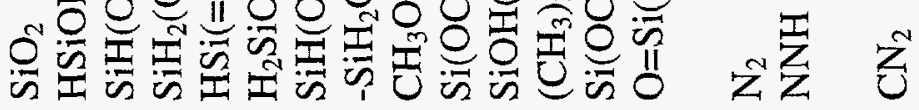

ب.

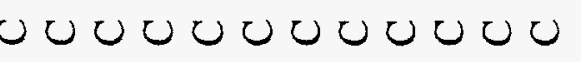

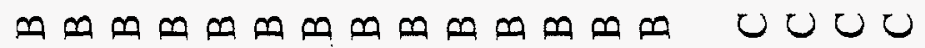

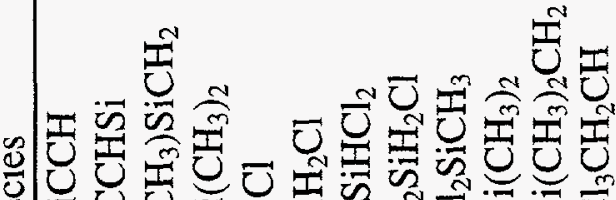

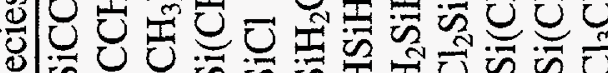

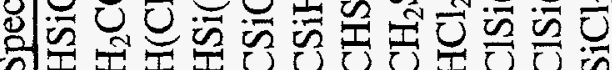

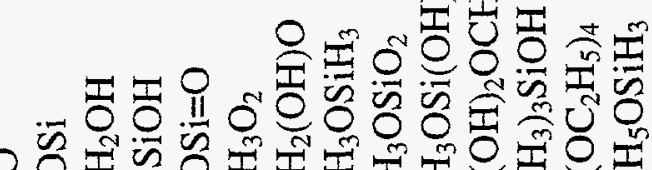

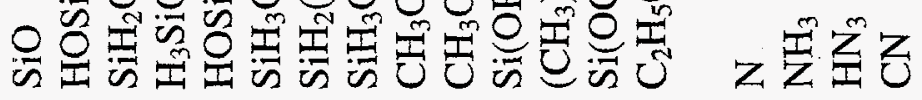




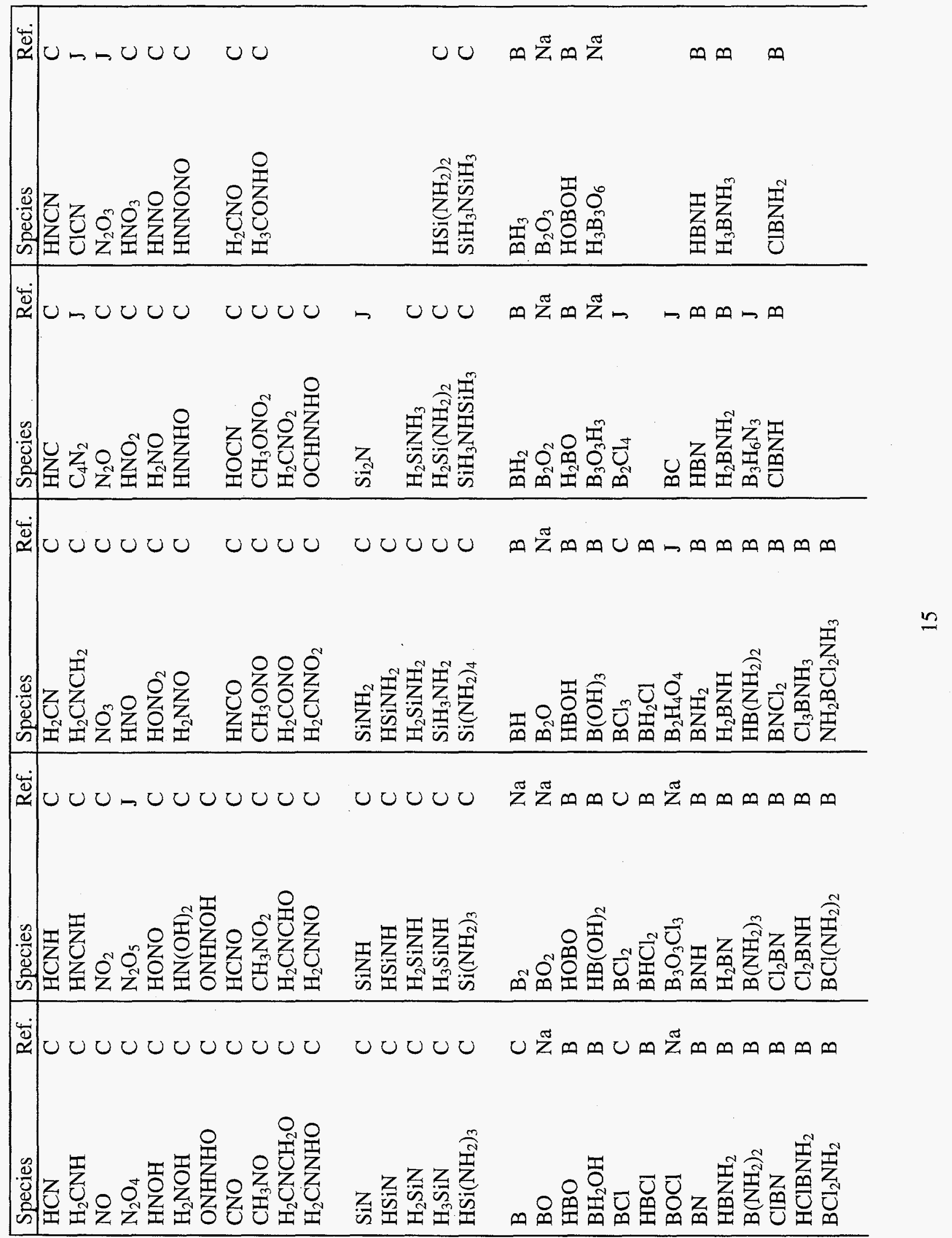


幽

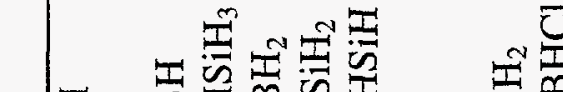

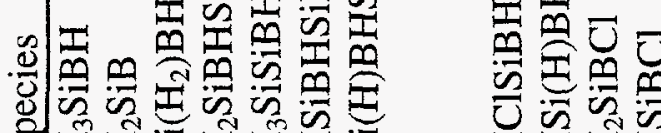

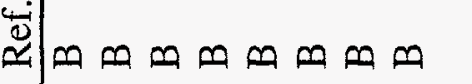

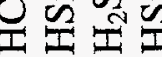

\section{İ}

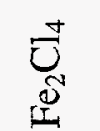

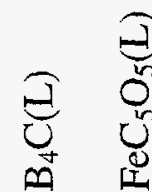

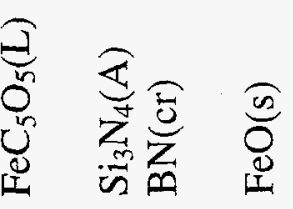

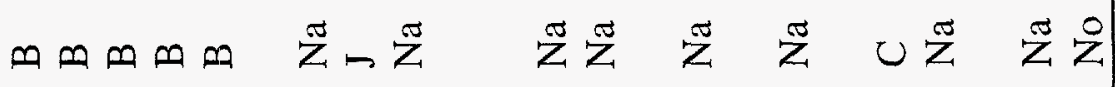

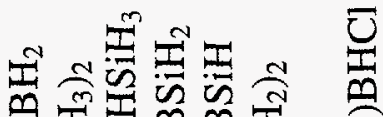

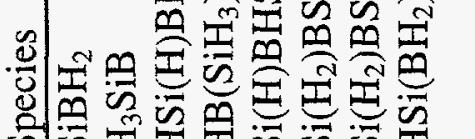

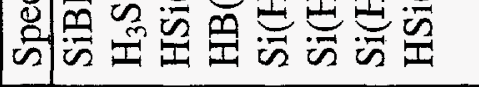

(4)

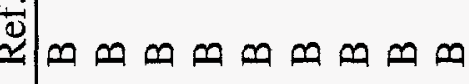

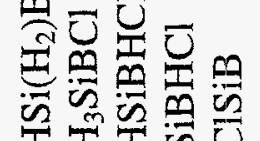

正的需

픈

它突

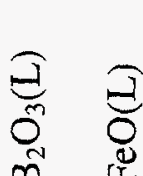

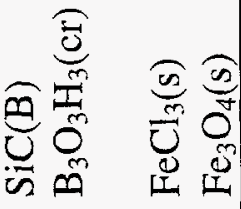

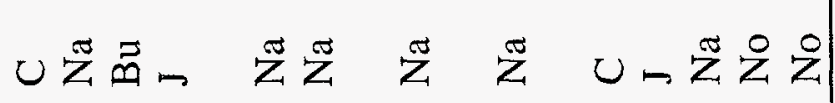

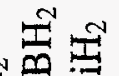

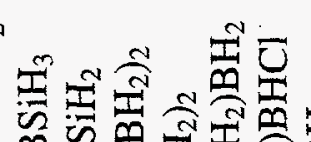

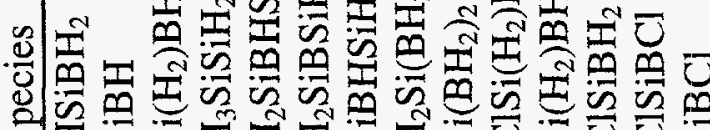

की

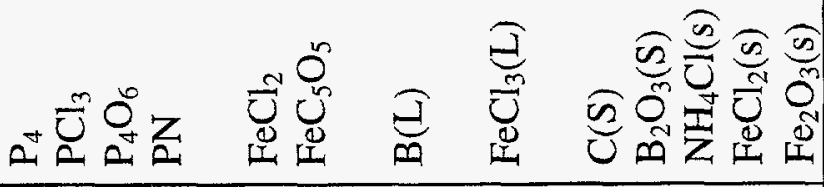

क्ष

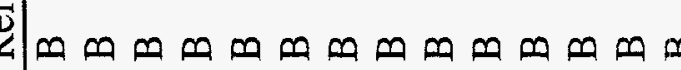

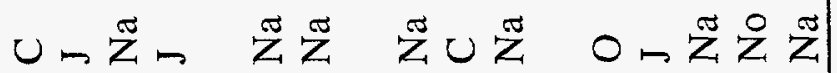

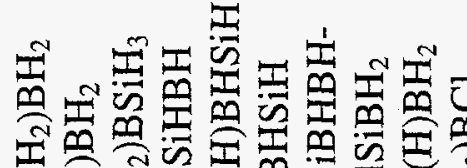

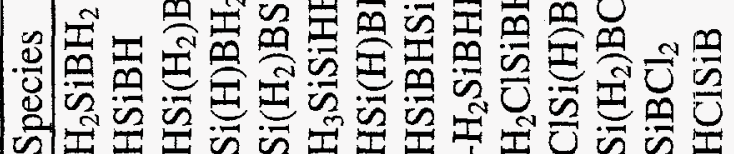

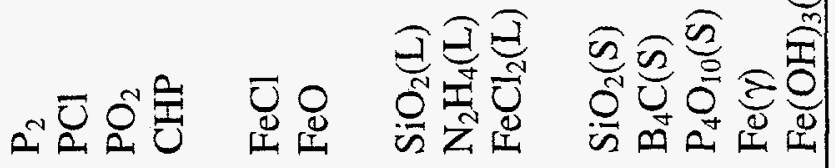

$\stackrel{4}{2}$

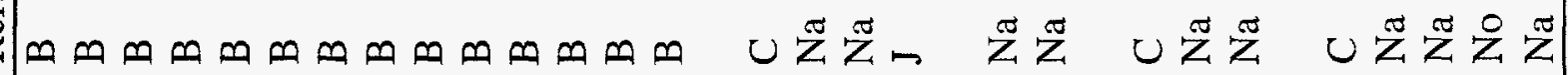

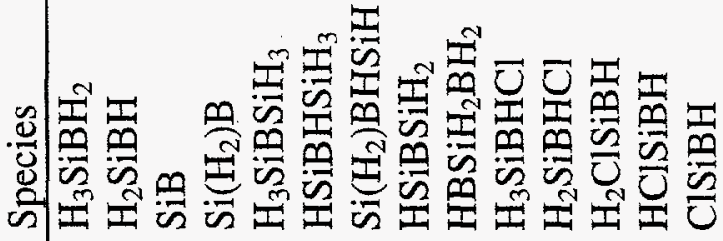

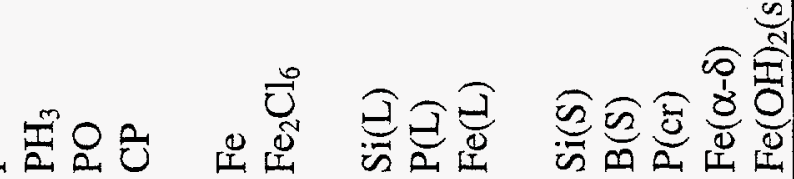


The CHEMKIN Thermodynamic Database [10,12] provided data for many gas-phase species, particularly molecules comprised of $\mathrm{C}, \mathrm{H}, \mathrm{O}$ and N. For most of the silicon-containing species, thermochemical data were obtained from quantum chemistry calculations using the BAC-MP4 method. This involves a combination of empirically-based corrections with relatively high-level $a b$ initio electronic structure calculations (see the original papers for details). For the Si-H-Cl [13], Si-C-H-Cl, [14] and Si-N-H [15] species, the thermochemical parameters from the BACMP4 calculations had already been incorporated into the CHEMKIN Thermodynamic Database. For the other systems, Si-O-H-C [16], Si-B-H-Cl [17] and B-H-N-Cl [18], the thermochemical data had to be compiled separately. In other cases, thermochemical data in the necessary format were obtained by extracting and fitting data from the JANAF Thermochemical Tables [19], or obtained from the NASA [20], Burcat [21] or Noring [22] Databases on the CHEMKIN Web Site on Sandia's intranet [23]. For $\mathrm{SiO}_{2}(\mathrm{~S})$, thermochemical data were obtained from work by Babushkin, et al. [24]. For the liquid and solid species, information on the bulk density was also needed as input, and are given in Table 2. The data were generally obtained from the CRC [25] or guessed based on related compounds. The calculations do not consider the free energy of mixing of the impurities in the silicon (such data generally do not exist).

Many of the species listed in Table 1 are unimportant under the conditions of interest. To avoid carrying lots of unimportant species throughout the analysis, this list was reduced substantially using the following process. For a given subset of the elements of interest, for example $\mathrm{Si}, \mathrm{O}, \mathrm{H}$ and $B$, equilibrium calculations were done using the full set of chemical species comprised of those elements for the extremes of pressure and temperature (i.e. 1700 and $2000 \mathrm{~K}, 0.001$ and 1.0 atm). If a species was present in any given phase only at low mole fractions (MF) for all these cases, it generally was dropped from further calculations. The thresholds for dropping a species depended on its composition, and were set at $\mathrm{MF}<10^{-10}$ for species containing $\mathrm{B}$ or $\mathrm{P}, \mathrm{MF}<$ $10^{-8}$ for species containing $\mathrm{C}$, or $\mathrm{MF}<10^{-7}$ for species comprised of $\mathrm{Si}, \mathrm{O}, \mathrm{H}, \mathrm{N}, \mathrm{Cl}$ only. $\mathrm{Fe}$ containing compounds were few enough that reduction was not an issue. Table 3 gives the reduced list of 153 chemical species actually used in the equilibrium analysis. 
Table 2. Densities for condensed phases species

\begin{tabular}{|c|c|c|}
\hline Species & $\begin{array}{l}\text { Density } \\
\left(\mathrm{g} / \mathrm{cm}^{3}\right)\end{array}$ & Data Source * \\
\hline $\operatorname{Si}(\mathrm{L})$ & 2.52 & CRC, at melting point \\
\hline $\mathrm{B}(\mathrm{L})$ & 2.08 & $\mathrm{CRC}$, at melting point \\
\hline $\mathrm{B}_{2} \mathrm{O}_{3}(\mathrm{~L})$ & 2.0 & guess \\
\hline $\mathrm{B}_{4} \mathrm{C}(\mathrm{L})$ & 2.3 & guess \\
\hline $\mathrm{P}(\mathrm{L})$ & 2.0 & guess \\
\hline $\mathrm{SiO}_{2}(\mathrm{~L})$ & 2.0 & guess \\
\hline $\mathrm{N}_{2} \mathrm{H}_{4}(\mathrm{~L})$ & 1.011 & $\mathrm{CRC}$ \\
\hline $\mathrm{Fe}(\mathrm{L})$ & 7.08 & $\mathrm{CRC}$, at melting point, average of seven numbers \\
\hline $\mathrm{FeC}_{5} \mathrm{O}_{5}(\mathrm{~L})$ & 1.457 & $\mathrm{CRC}$ \\
\hline $\mathrm{FeCl}_{2}(\mathrm{~L})$ & 3.1 & guess from solid \\
\hline $\mathrm{FeCl}_{3}(\mathrm{~L})$ & 3.0 & guess from solid \\
\hline $\mathrm{FeO}(\mathrm{L})$ & 5.0 & guess from solid \\
\hline $\mathrm{Si}(\mathrm{S})$ & 2.33 & CRC \\
\hline $\mathrm{SiO}_{2}(\mathrm{~S})$ & 2.19 & $\mathrm{CRC}$, lechatelierite \\
\hline $\mathrm{B}(\mathrm{S})$ & 2.35 & $\mathrm{CRC}$, average of two numbers \\
\hline $\mathrm{B}_{4} \mathrm{C}(\mathrm{S})$ & 2.52 & $\mathrm{CRC}$ \\
\hline $\mathrm{B}_{2} \mathrm{O}_{3}(\mathrm{~S})$ & 1.812 & CRC, glass \\
\hline $\mathrm{B}_{3} \mathrm{O}_{3} \mathrm{H}_{3}(\mathrm{cr})$ & 2.0 & guess \\
\hline $\mathrm{C}(\mathrm{S})$ & 2.25 & CRC, graphite \\
\hline $\operatorname{SiC}(B)$ & 3.217 & $\mathrm{CRC}$ \\
\hline $\mathrm{P}(\mathrm{cr})$ & 2.34 & CRC, red phosphorus, \\
\hline $\mathrm{P}_{4} \mathrm{O}_{10}(\mathrm{~S})$ & 2.39 & $\mathrm{CRC}$ \\
\hline $\mathrm{Si}_{3} \mathrm{~N}_{4}(\mathrm{~A})$ & 3.44 & $\mathrm{CRC}$ \\
\hline $\mathrm{BN}(\mathrm{cr})$ & 2.25 & CRC \\
\hline $\mathrm{NH}_{4} \mathrm{Cl}(\mathrm{a})$ & 1.527 & CRC \\
\hline $\mathrm{NH}_{4} \mathrm{Cl}(\mathrm{b})$ & 1.527 & CRC \\
\hline $\mathrm{Fe}(\alpha-\delta)$ & 7.86 & CRC \\
\hline $\mathrm{Fe}(\gamma)$ & 7.86 & $\mathrm{CRC}$ \\
\hline $\mathrm{FeCl}_{2}(\mathrm{~s})$ & 3.16 & CRC \\
\hline $\mathrm{FeCl}_{3}(\mathrm{~s})$ & 2.898 & CRC \\
\hline $\mathrm{FeO}(\mathrm{s})$ & 5.7 & CRC, wuestite \\
\hline $\mathrm{Fe}(\mathrm{OH})_{2}(\mathrm{~s})$ & 3.4 & CRC \\
\hline $\mathrm{Fe}(\mathrm{OH})_{3}(\mathrm{~s})$ & 3.0 & guess from above \\
\hline $\mathrm{Fe}_{2} \mathrm{O}_{3}(\mathrm{~s})$ & 5.24 & CRC, hematite \\
\hline $\mathrm{Fe}_{3} \mathrm{O}_{4}(\mathrm{~s})$ & 5.18 & $\mathrm{CRC}$, magnetite \\
\hline
\end{tabular}

* CRC $=$ Ref. [25] 
Table 3. Chemical species actually used in equilibrium calculations.

\begin{tabular}{|c|c|c|c|c|c|}
\hline GASES & & & & & \\
\hline $\mathrm{Ar}$ & $\overline{\mathrm{Si}}$ & $\overline{\mathrm{Si}_{2}}$ & $\mathrm{Si}_{3}$ & & \\
\hline $\mathrm{H}$ & $\mathrm{H}_{2}$ & $\mathrm{Cl}$ & $\mathrm{Cl}_{2}$ & $\mathrm{HCl}$ & \\
\hline $\mathrm{SiH}$ & $\mathrm{SiH}_{2}$ & $\mathrm{SiH}_{3}$ & $\mathrm{SiH}_{4}$ & & \\
\hline $\mathrm{SiClH}_{3}$ & $\mathrm{SiCl}_{3} \mathrm{H}$ & $\mathrm{SiCl}_{2} \mathrm{H}_{2}$ & $\mathrm{HSiCl}$ & $\mathrm{SiH}_{2} \mathrm{Cl}$ & $\mathrm{SiHCl}_{2}$ \\
\hline $\mathrm{SiCl}$ & $\mathrm{SiCl}_{2}$ & $\mathrm{SiCl}_{3}$ & $\mathrm{SiCl}_{4}$ & & \\
\hline $\mathrm{Si}_{2} \mathrm{Cl}_{5}$ & $\mathrm{Si}_{2} \mathrm{Cl}_{5} \mathrm{H}$ & $\mathrm{Si}_{2} \mathrm{Cl}_{6}$ & $\mathrm{HCl}_{2} \mathrm{SiSiCl}_{2} \mathrm{H}$ & $\mathrm{Cl}_{2} \mathrm{SiSiCl}_{2}$ & $\mathrm{Cl}_{3} \mathrm{SiSiCl}$ \\
\hline $\mathrm{Cl}_{3} \mathrm{SiSi}$ & $\mathrm{Cl}_{2} \mathrm{SiSiCl}$ & $\mathrm{Cl}_{2} \mathrm{SiSi}$ & ClSiSiCl & ClSiSi & \\
\hline $\mathrm{O}_{2}$ & $\mathrm{OH}$ & $\mathrm{H}_{2} \mathrm{O}$ & & & \\
\hline $\mathrm{CO}$ & $\mathrm{CO}_{2}$ & $\mathrm{CH}_{3}$ & $\mathrm{CH}_{4}$ & $\mathrm{C}_{2} \mathrm{H}_{2}$ & \\
\hline $\mathrm{SiC}$ & $\mathrm{SiC}_{2}$ & $\mathrm{SiCH}$ & $\mathrm{SiCH}_{2}$ & $\mathrm{Si}_{2} \mathrm{C}$ & \\
\hline $\mathrm{CH}_{2} \mathrm{SiCl}_{3}$ & $\mathrm{CH}_{3} \mathrm{SiCl}$ & $\mathrm{Cl}_{3} \mathrm{SiCH}_{3}$ & $\mathrm{H}_{2} \mathrm{ClSiSiCl}_{3}$ & & \\
\hline $\mathrm{HSi}=\mathrm{O}$ & HOSi & $\mathrm{SiO}$ & -SiOSiO- & & \\
\hline $\mathrm{N}$ & $\mathrm{N}_{2}$ & $\mathrm{NH}$ & $\mathrm{NH}_{2}$ & $\mathrm{NH}_{3}$ & \\
\hline NO & $\mathrm{CN}$ & $\mathrm{HCN}$ & $\mathrm{HNC}$ & $\mathrm{ClCN}$ & \\
\hline SiN & SiNH & $\mathrm{SiNH}_{2}$ & $\mathrm{Si}_{2} \mathrm{~N}$ & & \\
\hline B & BO & $\mathrm{B}_{2} \mathrm{O}_{2}$ & $\mathrm{HBO}$ & HOBO & $\mathrm{BH}_{2} \mathrm{OH}$ \\
\hline BH & $\mathrm{BH}_{2}$ & $\mathrm{BH}_{3}$ & $\mathrm{BCl}$ & $\mathrm{BCl}_{2}$ & $\mathrm{BCl}_{3}$ \\
\hline $\mathrm{HBCl}$ & $\mathrm{BHCl}_{2}$ & $\mathrm{BH}_{2} \mathrm{Cl}$ & $\mathrm{BOCl}$ & & \\
\hline BN & $\mathrm{BNH}$ & $\mathrm{BNH}_{2}$ & $\mathrm{~B}\left(\mathrm{NH}_{2}\right)_{2}$ & $\mathrm{~B}\left(\mathrm{NH}_{2}\right)_{3}$ & $\mathrm{~B}_{3} \mathrm{~N}_{3} \mathrm{H}_{6}$ \\
\hline $\mathrm{H}_{2} \mathrm{BN}$ & $\mathrm{H}_{2} \mathrm{BNH}$ & $\mathrm{H}_{2} \mathrm{BNH}_{2}$ & $\mathrm{H}_{3} \mathrm{BNH}_{3}$ & $\mathrm{HB}\left(\mathrm{NH}_{2}\right)_{2}$ & \\
\hline HBN & HBNH & $\mathrm{HBNH}_{2}$ & CIBNH & $\mathrm{BCl}_{2} \mathrm{NH}_{2}$ & \\
\hline $\mathrm{SiBH}$ & $\mathrm{SiBCl}$ & $\mathrm{SiBCl}_{2}$ & & & \\
\hline $\mathrm{P}$ & $\mathrm{P}_{2}$ & $\mathrm{PH}$ & $\mathrm{PH}_{2}$ & $\mathrm{PH}_{3}$ & \\
\hline $\mathrm{PCl}$ & $\mathrm{PCl}_{3}$ & $\mathrm{PO}$ & $\mathrm{CP}^{-}$ & CHP & PN \\
\hline $\mathrm{Fe}$ & $\mathrm{FeCl}$ & $\mathrm{FeCl}_{2}$ & $\mathrm{FeCl}_{3}$ & $\mathrm{Fe}_{2} \mathrm{Cl}_{4}$ & $\mathrm{Fe}_{2} \mathrm{Cl}_{6}$ \\
\hline $\mathrm{FeO}$ & $\mathrm{FeC}_{5} \mathrm{O}_{5}$ & $\mathrm{Fe}(\mathrm{OH})_{2}$ & & & \\
\hline LIQUIDS & & & & & \\
\hline$\overline{\mathrm{Si}(\mathrm{L})}$ & $\mathrm{SiO}_{2}(\mathrm{~L})$ & & & & \\
\hline $\mathrm{B}(\mathrm{L})$ & $\mathrm{B}_{2} \mathrm{O}_{3}(\mathrm{~L})$ & & & & \\
\hline $\mathrm{P}(\mathrm{L})$ & & & & & \\
\hline $\mathrm{Fe}(\mathrm{L})$ & $\mathrm{FeCl}_{2}(\mathrm{~L})$ & $\mathrm{FeCl}_{3}(\mathrm{~L})$ & $\mathrm{FeO}(\mathrm{L})$ & & \\
\hline SOLIDS & & & & & \\
\hline $\mathrm{Si}(\mathrm{S})$ & $\mathrm{SiO}_{2}(\mathrm{~S})$ & $\mathrm{SiC}(\mathrm{B})$ & $\mathrm{Si}_{3} \mathrm{~N}_{4}(\mathrm{~A})$ & & \\
\hline $\mathrm{B}(\mathrm{S})$ & $\mathrm{B}_{2} \mathrm{O}_{3}(\mathrm{~S})$ & $\mathrm{BN}(\mathrm{cr})$ & & & \\
\hline$C(S)$ & & & & & \\
\hline $\mathrm{P}(\mathrm{cr})$ & & & & & \\
\hline $\mathrm{NH}_{4} \mathrm{Cl}(\mathrm{a})$ & $\mathrm{NH}_{4} \mathrm{Cl}(\mathrm{b})$ & & & & \\
\hline $\mathrm{Fe}(\mathrm{s}, \mathrm{a}-\mathrm{d})$ & $\mathrm{Fe}(\mathrm{s}$,gamma) & $\mathrm{FeCl}_{2}(\mathrm{~s})$ & $\mathrm{FeCl}_{3}(\mathrm{~s})$ & & \\
\hline $\mathrm{FeO}(\mathrm{s})$ & $\mathrm{Fe}(\mathrm{OH})_{2}(\mathrm{~s})$ & $\mathrm{Fe}(\mathrm{OH})_{3}(\mathrm{~s})$ & $\mathrm{Fe}_{2} \mathrm{O}_{3}(\mathrm{~s})$ & $\mathrm{Fe}_{3} \mathrm{O}_{4}(\mathrm{~s})$ & \\
\hline
\end{tabular}




\section{Results}

The EQUIL code outputs a list of the species with significant mole fractions in the starting and equilibrium mixtures, followed by the number of moles and lists of the full species mole fractions for each of the phases (gas, liquid, solid). The Appendix gives an example of an EQUIL output file. These outputs were post-processed by adding up the number of moles of species containing a given element $(\mathrm{Si}, \mathrm{B}, \mathrm{P}, \mathrm{C}$ or $\mathrm{Fe}$ ) in each of the liquid and solid phases, then normalizing them to the input number of moles of that element. The remainder was assumed to be in the gas phase.

The subsections below discuss the effects of adding a variety of gases to the standard silicon/impurities mixture. Each subsection includes figures showing the equilibrium distribution between the gas, liquid and solid phases of silicon, boron, phosphorus, carbon and iron, as well as the overall mole fraction for a variety of temperatures and total pressures. These figures show a few general features. As expected, the overall mole fraction distribution generally mirrors that of silicon, the primary component of the mixture, and is primarily molten. (Note that the over all mole fraction distribution always contains the 0.01 mole of inert argon included in the input mixture.) Lower total pressures and higher temperatures favor the gas phase, whereas higher total pressures and lower temperatures favor the condensed phases. Phosphorus and iron vaporize to a certain extent at high temperature and low pressure, independent of the added gases.

Tables listing the identity of the dominant chemical species containing $\mathrm{Si}, \mathrm{B}, \mathrm{P}, \mathrm{C}$ and $\mathrm{Fe}$ in each phase are also given. This information is useful in separating chemical effects from simple vaporization or melting, although the latter may be useful as purification processes. Somewhat arbitrarily, a "dominant" species has been defined as one accounting for at least $\sim 20 \%$ of that element in that phase. For completeness, the tables include entries even in cases where a given phase is only present to a very minor extent. 


\section{A. Oxygen Addition}

Figure 1 gives the equilibrium distribution of the overall MF, Si, B, P, C and Fe among the gas, liquid and solid phases for exposure to oxygen at $1450^{\circ} \mathrm{C}$ and total pressures of $0.001,0.01,0.1$ and 1.0 atmospheres. Figure 2 gives the corresponding results at $1550^{\circ} \mathrm{C}$ and Figure 3 the results at $1650^{\circ} \mathrm{C}$. Table 4 gives information on chemical species identities for the same sets of conditions.

These figures show that at the higher pressures, the $\mathrm{C}$ and $\mathrm{Fe}$ are generally solids, the $\mathrm{P}$ is generally liquid along the $\mathrm{Si}$, and the $\mathrm{B}$ is mostly liquid with some solid. In all cases, the input $\mathrm{O}_{2}$ reacts away almost completely. At the lower pressures, and particularly at the higher temperatures, more vapor-phase species are present, dominated by $\mathrm{SiO}$, which represents loss of silicon. However, substantial fractions of the $\mathrm{C}$ can be converted to $\mathrm{CO}$, while significant amounts of $\mathrm{P}$ and Fe can vaporize. Small amounts of $\mathrm{BO}$ are formed, but the conversion is quite low for the purposes of a purification process, given that the total amount of oxygen exposure will be limited by the concomitant loss of silicon via $\mathrm{SiO}$ formation. The $\mathrm{C}$ in the solid phase is primarily silicon carbide, which is only somewhat denser than silicon. Overall, it appears that $\mathrm{O}_{2}$ is a good candidate for removing $\mathrm{C}$ by oxidation to $\mathrm{CO}$, but is unlikely to be a good route for vaporizing the other impurities. 

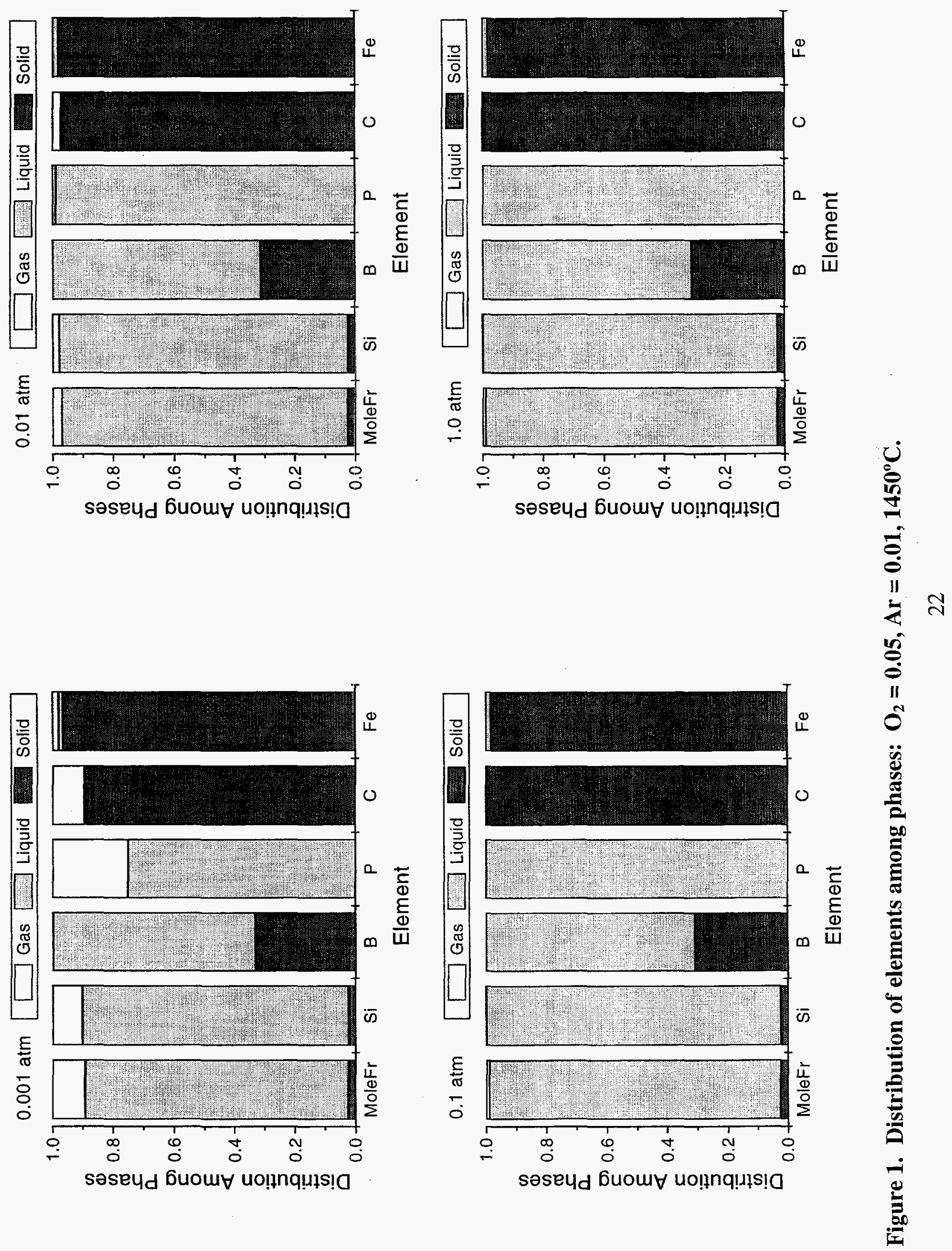

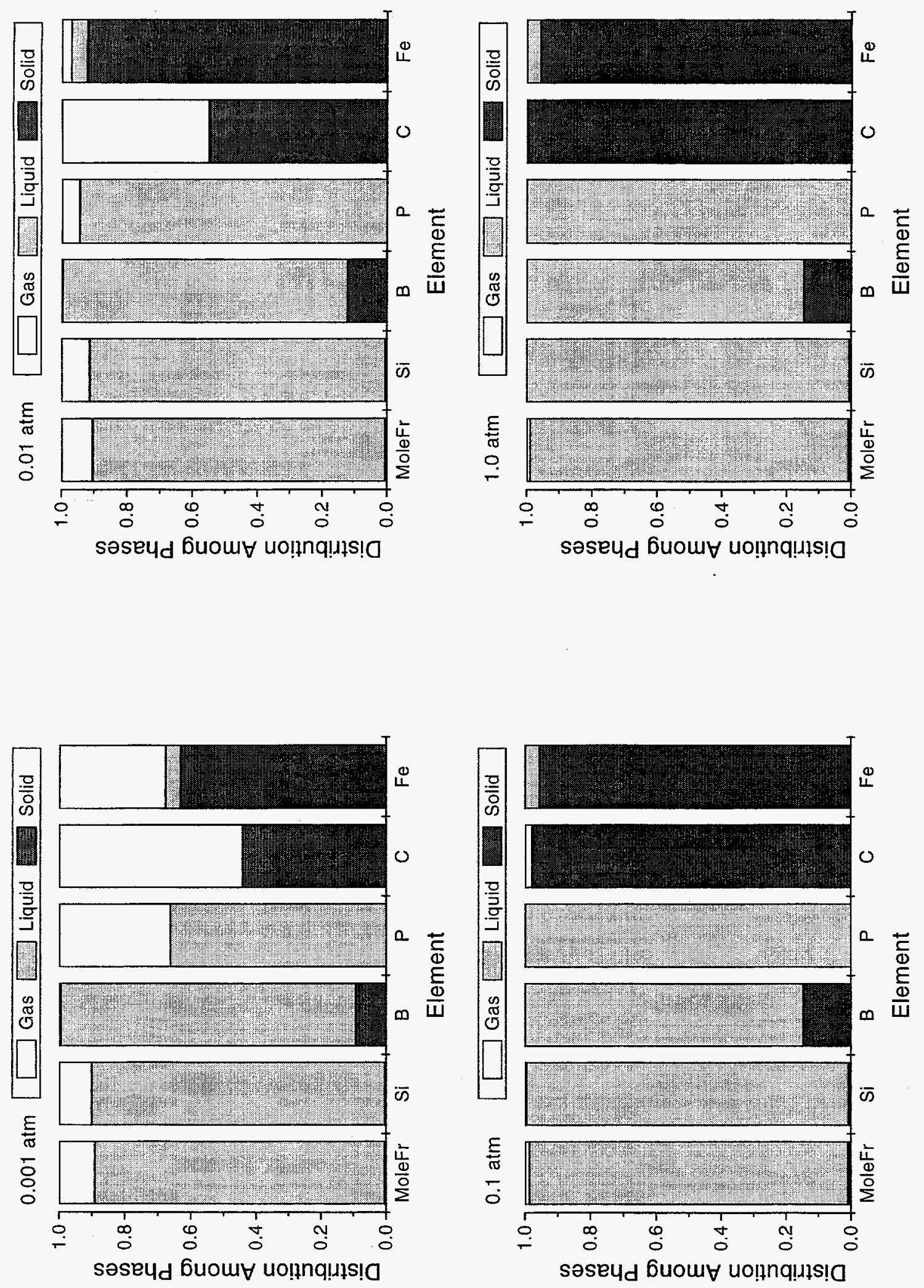

ن 

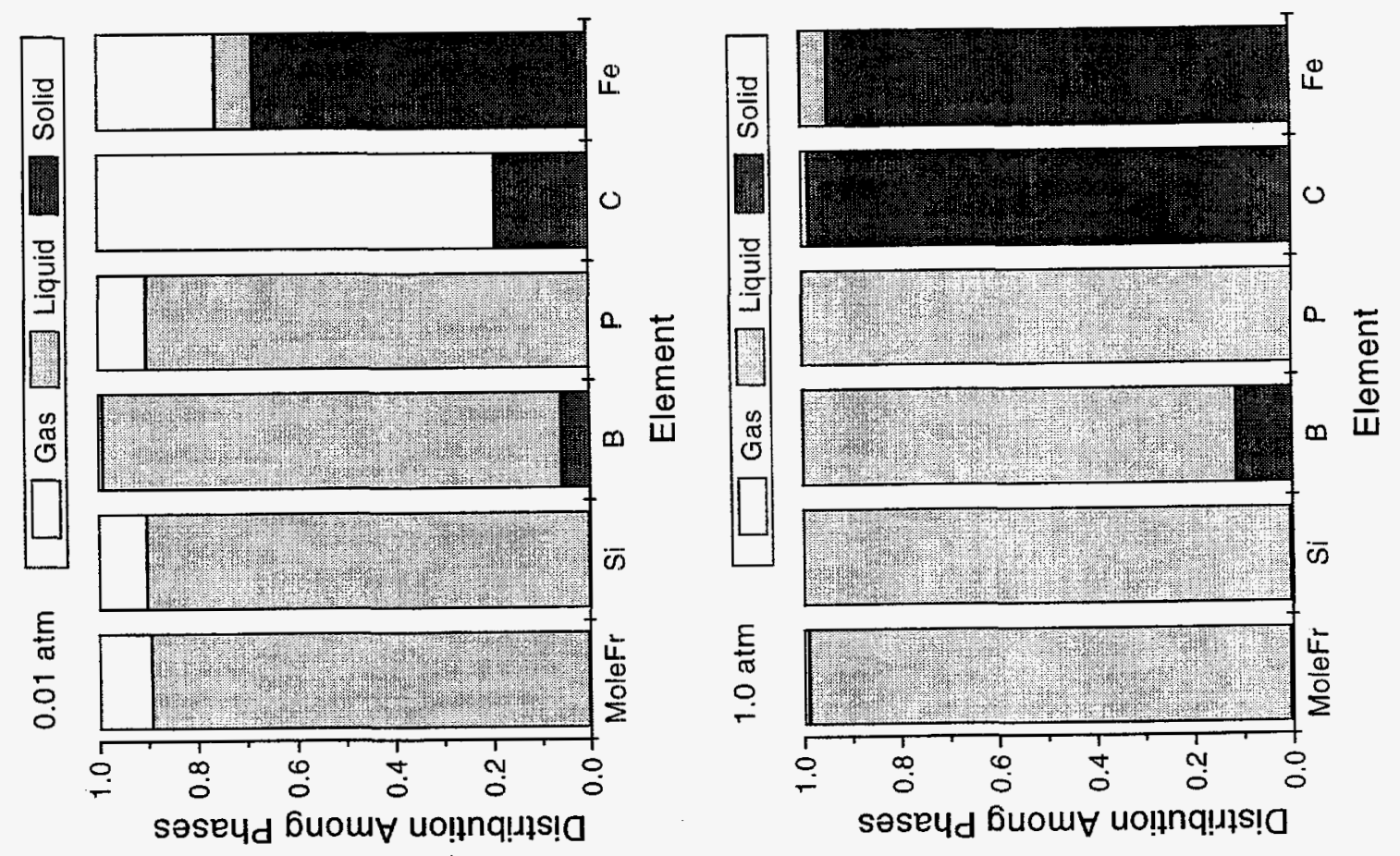

官
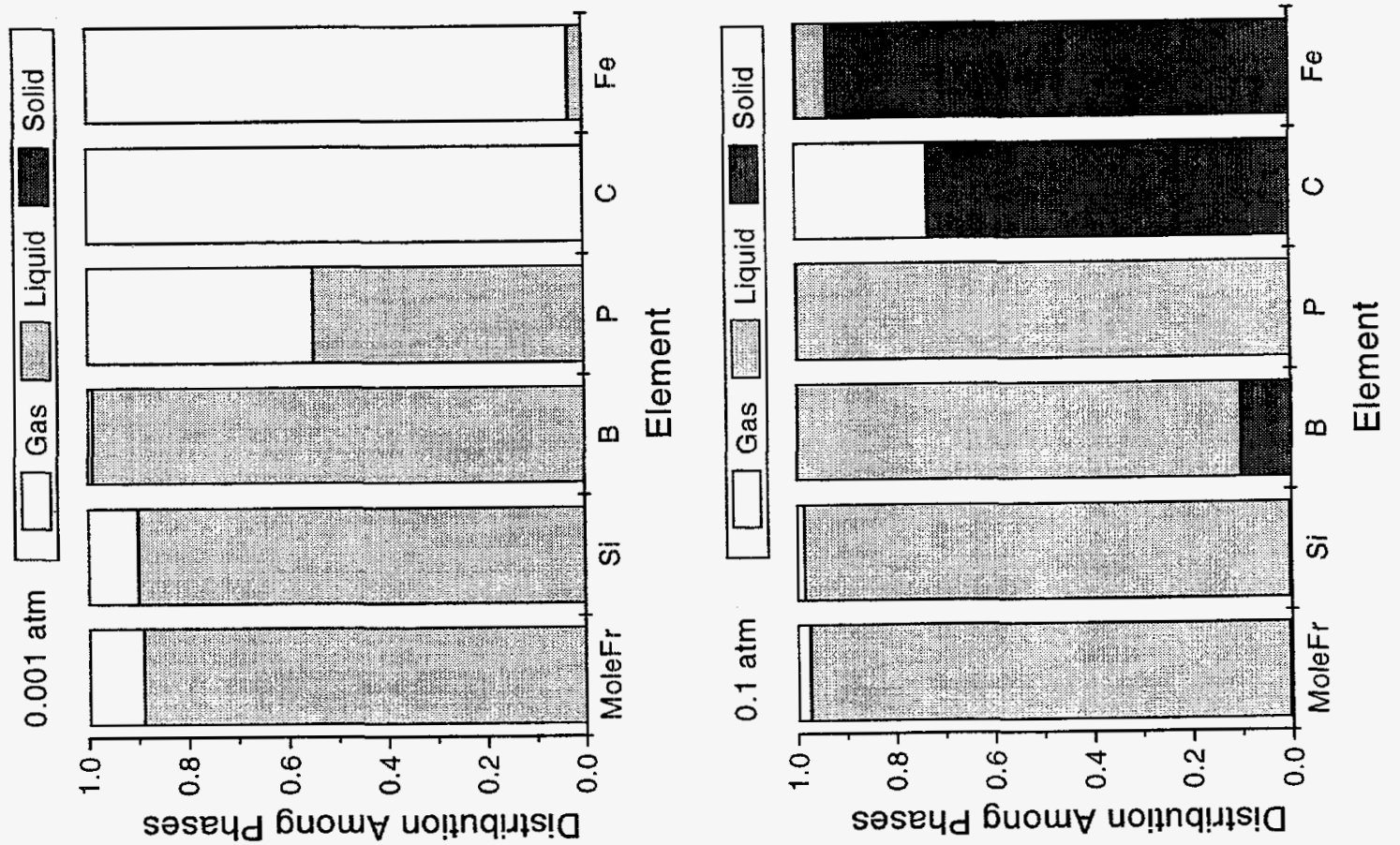
Table 4. Dominant* chemical species for silicon and impurities with $\mathrm{O}_{2} / \mathrm{Ar}$ addition.

\begin{tabular}{|c|c|c|c|c|c|c|c|}
\hline $\begin{array}{l}\text { Temp. } \\
\left({ }^{\circ} \mathrm{C}\right)\end{array}$ & $\begin{array}{l}\text { Pressure } \\
\text { (atm) }\end{array}$ & Phase & $\mathrm{Si}$ & B & $P$ & C & $\mathrm{Fe}$ \\
\hline 1450 & $\begin{array}{l}0.001- \\
1.0\end{array}$ & $\begin{array}{l}\text { Gas } \\
\text { Liquid } \\
\text { Solid }\end{array}$ & $\begin{array}{l}\mathrm{SiO} \\
\mathrm{Si}(\mathrm{L}) \\
\mathrm{Si}(\mathrm{S})\end{array}$ & $\begin{array}{l}\mathrm{BO} \\
\mathrm{B}(\mathrm{L}) \\
\mathrm{B}(\mathrm{S})\end{array}$ & $\begin{array}{l}\mathrm{P}_{2} \\
\mathrm{P}(\mathrm{L}) \\
\mathrm{P}(\mathrm{cr})\end{array}$ & $\begin{array}{l}\mathrm{CO} \\
- \\
\mathrm{SiC}(\mathrm{B})\end{array}$ & $\begin{array}{l}\mathrm{Fe} \\
\mathrm{Fe}(\mathrm{L}) \\
\mathrm{Fe}(\alpha, \delta, \gamma)\end{array}$ \\
\hline 1550 & 0.001 & $\begin{array}{l}\text { Gas } \\
\text { Liquid } \\
\text { Solid }\end{array}$ & $\begin{array}{l}\mathrm{SiO} \\
\mathrm{Si}(\mathrm{L}) \\
\mathrm{Si}(\mathrm{S})\end{array}$ & $\begin{array}{l}\text { BO } \\
\mathrm{B}(\mathrm{L}) \\
\mathrm{B}(\mathrm{S})\end{array}$ & $\begin{array}{l}\mathrm{P}_{2}, \mathrm{P} \\
\mathrm{P}(\mathrm{L}) \\
\mathrm{P}(\mathrm{cr})\end{array}$ & $\begin{array}{l}\mathrm{CO} \\
- \\
\mathrm{SiC}(\mathrm{B})\end{array}$ & $\begin{array}{l}\mathrm{Fe} \\
\mathrm{Fe}(\mathrm{L}) \\
\mathrm{Fe}(\alpha, \delta, \gamma)\end{array}$ \\
\hline 1550 & $\begin{array}{l}0.01- \\
1.0\end{array}$ & $\begin{array}{l}\text { Gas } \\
\text { Liquid } \\
\text { Solid }\end{array}$ & $\begin{array}{l}\mathrm{SiO} \\
\mathrm{Si}(\mathrm{L}) \\
\mathrm{Si}(\mathrm{S})\end{array}$ & $\begin{array}{l}\text { BO } \\
\mathrm{B}(\mathrm{L}) \\
\mathrm{B}(\mathrm{S})\end{array}$ & $\begin{array}{l}\mathrm{P}_{2} \\
\mathrm{P}(\mathrm{L}) \\
\mathrm{P}(\mathrm{cr})\end{array}$ & $\begin{array}{l}\mathrm{CO} \\
- \\
\mathrm{SiC}(\mathrm{B}) \\
\end{array}$ & $\begin{array}{l}\mathrm{Fe} \\
\mathrm{Fe}(\mathrm{L}) \\
\mathrm{Fe}(\alpha, \delta, \gamma)\end{array}$ \\
\hline 1650 & 0.001 & $\begin{array}{l}\text { Gas } \\
\text { Liquid } \\
\text { Solid }\end{array}$ & $\begin{array}{l}\mathrm{SiO} \\
\mathrm{Si}(\mathrm{L}) \\
--\end{array}$ & $\begin{array}{l}\mathrm{BO} \\
\mathrm{B}(\mathrm{L}) \\
--\end{array}$ & $\begin{array}{l}\mathrm{P}_{2}, \mathrm{P} \\
\mathrm{P}(\mathrm{L}) \\
--\end{array}$ & $\begin{array}{l}\mathrm{CO} \\
-- \\
-- \\
\end{array}$ & $\begin{array}{l}\mathrm{Fe} \\
\mathrm{Fe}(\mathrm{L}) \\
--\end{array}$ \\
\hline 1650 & 0.01 & $\begin{array}{l}\text { Gas } \\
\text { Liquid } \\
\text { Solid }\end{array}$ & $\begin{array}{l}\mathrm{SiO} \\
\mathrm{Si}(\mathrm{L}) \\
\mathrm{Si}(\mathrm{S})\end{array}$ & $\begin{array}{l}\mathrm{BO} \\
\mathrm{B}(\mathrm{L}) \\
\mathrm{B}(\mathrm{S})\end{array}$ & $\begin{array}{l}\mathrm{P}_{2}, \mathrm{P} \\
\mathrm{P}(\mathrm{L}) \\
\mathrm{P}(\mathrm{cr})\end{array}$ & $\begin{array}{l}\mathrm{CO} \\
-- \\
\mathrm{SiC}(\mathrm{B})\end{array}$ & $\begin{array}{l}\mathrm{Fe} \\
\mathrm{Fe}(\mathrm{L}) \\
\mathrm{Fe}(\alpha, \delta, \gamma)\end{array}$ \\
\hline 1650 & $\begin{array}{l}0.1- \\
1.0\end{array}$ & $\begin{array}{l}\text { Gas } \\
\text { Liquid } \\
\text { Solid } \\
\end{array}$ & $\begin{array}{l}\mathrm{SiO} \\
\mathrm{Si}(\mathrm{L}) \\
\mathrm{Si}(\mathrm{S}), \mathrm{SiC}(\mathrm{B})\end{array}$ & $\begin{array}{l}\mathrm{BO} \\
\mathrm{B}(\mathrm{L}) \\
\mathrm{B}(\mathrm{S})\end{array}$ & $\begin{array}{l}\mathrm{P}_{2}, \mathrm{P} \\
\mathrm{P}(\mathrm{L}) \\
\mathrm{P}(\mathrm{cr})\end{array}$ & $\begin{array}{l}\mathrm{CO} \\
- \\
\mathrm{SiC}(\mathrm{B})\end{array}$ & $\begin{array}{l}\mathrm{Fe} \\
\mathrm{Fe}(\mathrm{L}) \\
\mathrm{Fe}(\alpha, \delta, \gamma)\end{array}$ \\
\hline
\end{tabular}

* Chemical species are listed for each phase in order of decreasing mole fraction as a function of temperature and pressure. If multiple species are listed, each represents at least $\sim 20 \%$ of the element in that phase. 


\section{B. Air Addition}

Air is simple to obtain and straightforward to handle experimentally. Figure 4 through Figure 6 and Table 5 give the equilibrium results for reaction of the silicon/impurities mixture with air. As for the case of oxygen exposure presented above, the oxygen reacts away to form $\mathrm{SiO}, \mathrm{CO}$ and small amount of BO. Air is only $20 \%$ oxygen, so the total amount of $\mathrm{C}$ converted to $\mathrm{CO}$, even at the highest temperature and lowest pressure, is lower than for the $\mathrm{O}_{2}$ case. The presence of nitrogen, however, results in PN formation in the gas at low pressures, and in $\mathrm{BN}(\mathrm{cr})$ formation at higher pressures. The latter conditions also result in significant $\mathrm{Si}_{3} \mathrm{~N}_{4}(\mathrm{~A})$ formation, which would result in loss of silicon. With the caveat that $\mathrm{N}_{2}$ is very likely to have kinetic barriers that will hinder reaction, it appears that air has potential for removal of $\mathrm{C}, \mathrm{P}$ and some $\mathrm{B}$ if the solid is separable from the silicon. 

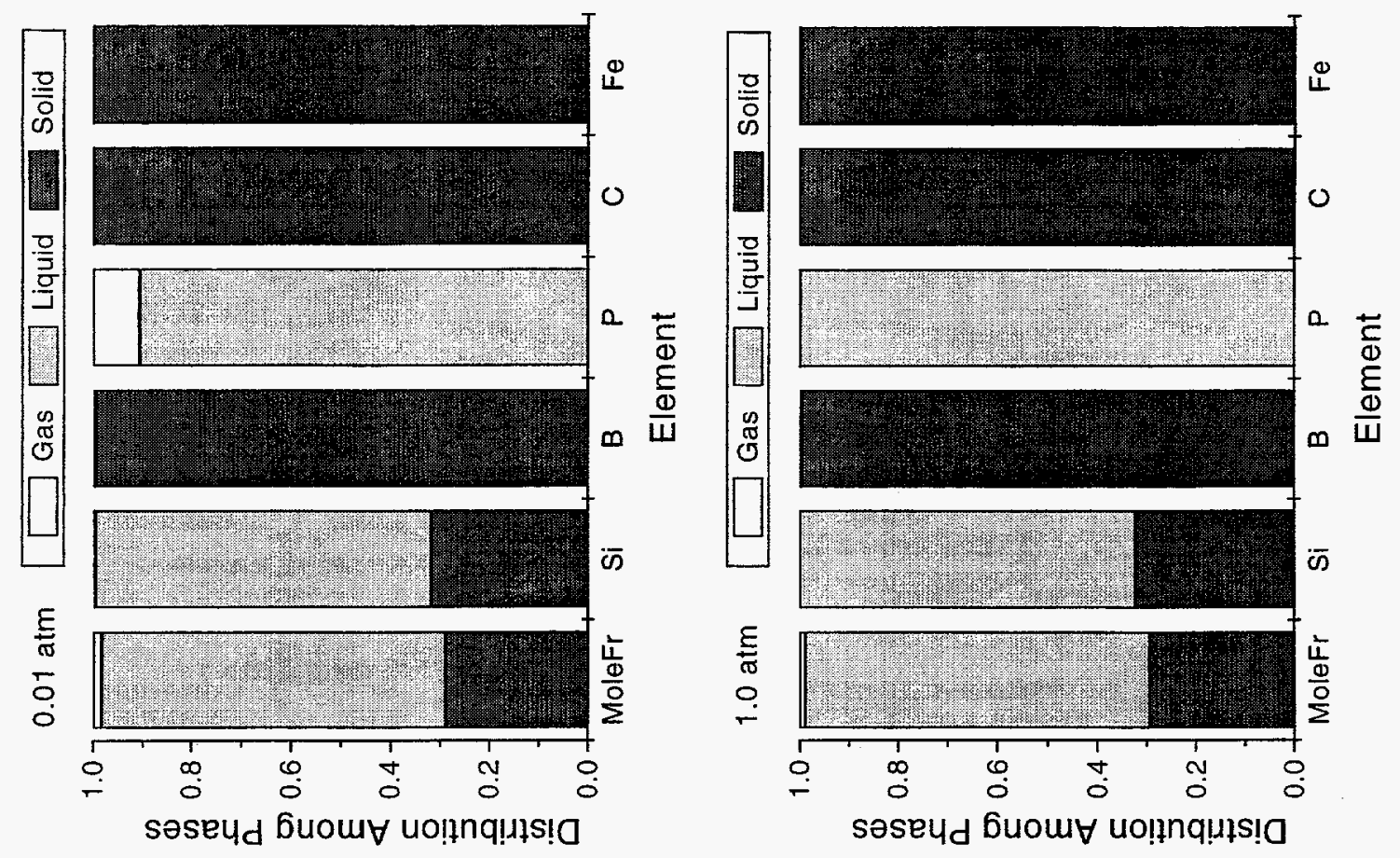

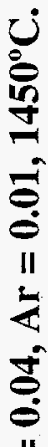
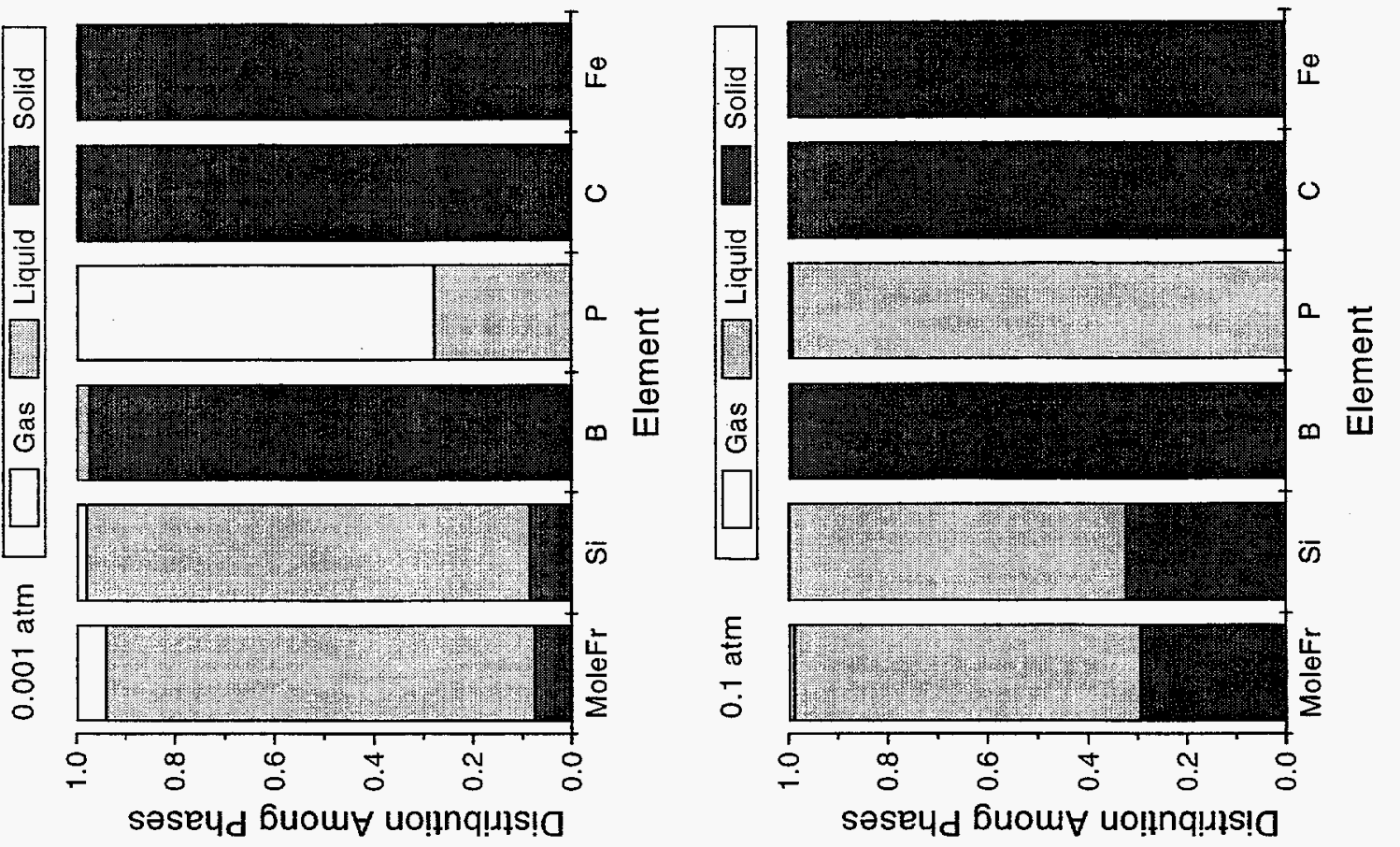

$N$ 

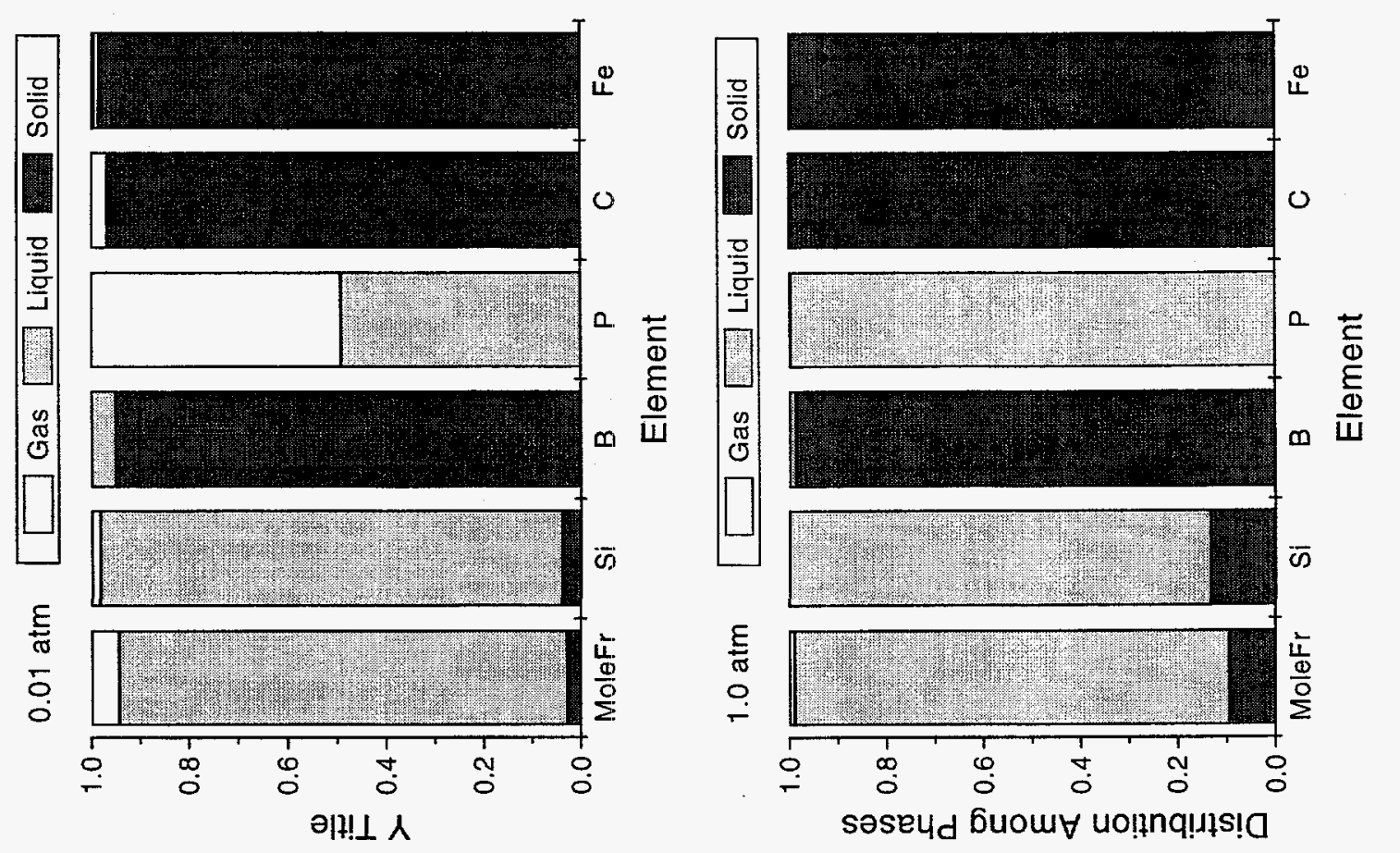

告
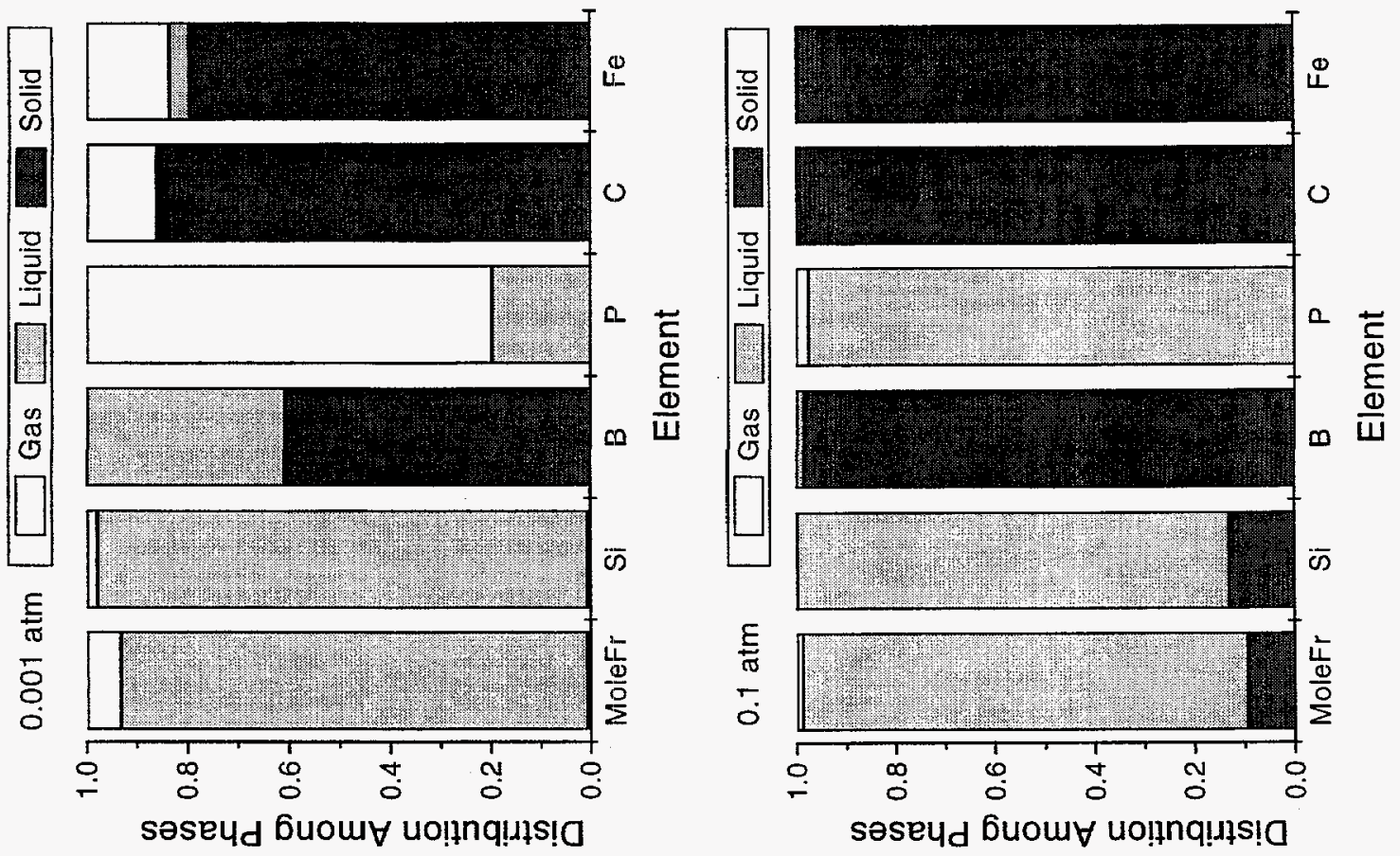

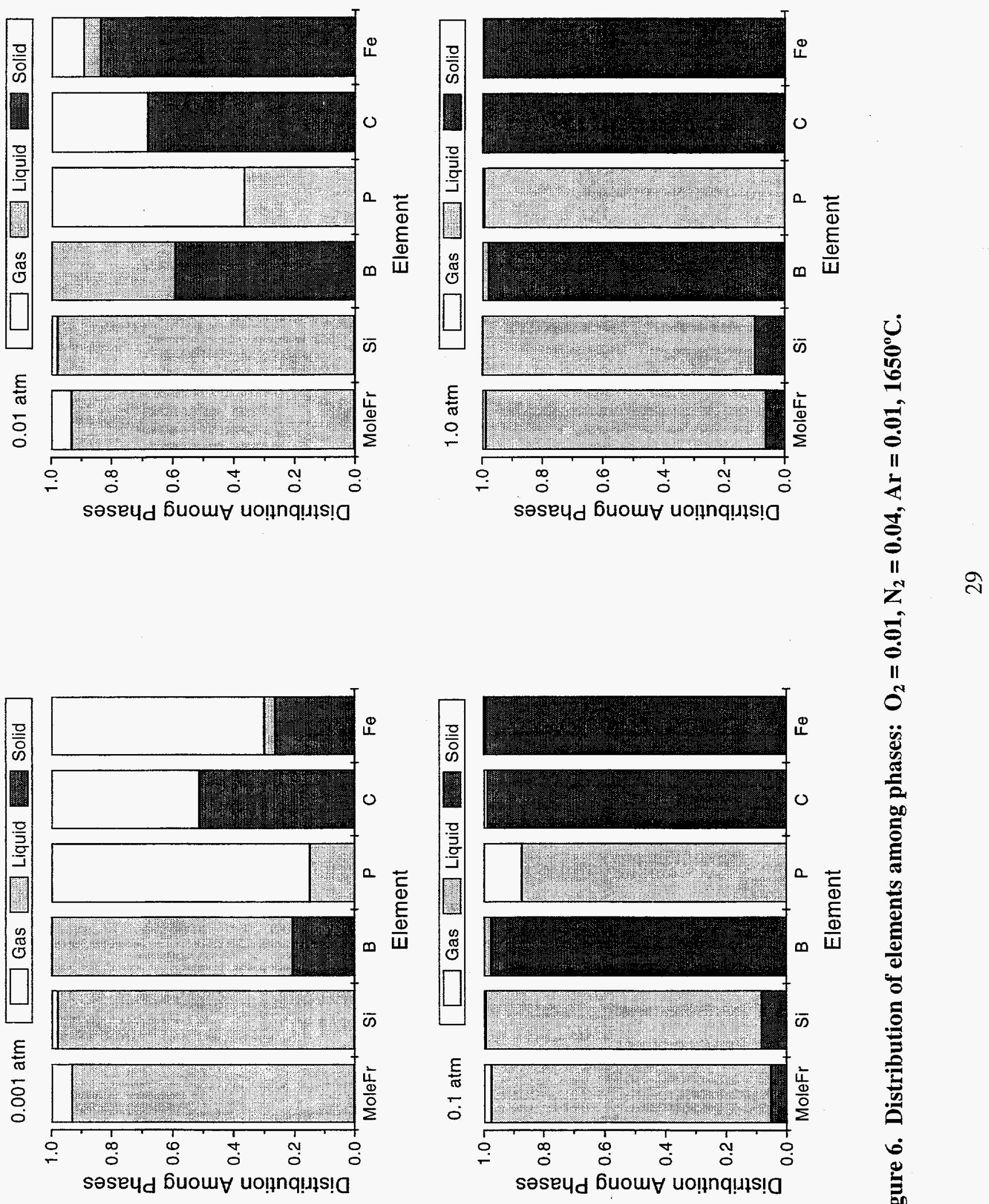
Table 5. Dominant* chemical species for silicon and impurities with $\mathrm{O}_{2} / \mathrm{N}_{2} / \mathrm{Ar}$ addition.

\begin{tabular}{|c|c|c|c|c|c|c|c|}
\hline $\begin{array}{l}\text { Temp. } \\
\left({ }^{\circ} \mathrm{C}\right)\end{array}$ & $\begin{array}{l}\text { Pressure } \\
\text { (atm) }\end{array}$ & Phase & $\mathrm{Si}$ & B & $P$ & C & $\mathrm{Fe}$ \\
\hline 1450 & 0.001 & $\begin{array}{l}\text { Gas } \\
\text { Liquid } \\
\text { Solid }\end{array}$ & $\begin{array}{l}\mathrm{SiO} \\
\mathrm{Si}(\mathrm{L}) \\
\mathrm{Si}(\mathrm{S})\end{array}$ & $\begin{array}{l}\mathrm{BO} \\
\mathrm{B}(\mathrm{L}) \\
\mathrm{BN}(\mathrm{cr})\end{array}$ & $\begin{array}{l}\mathrm{PN} \\
\mathrm{P}(\mathrm{L}) \\
\mathrm{P}(\mathrm{cr})\end{array}$ & $\begin{array}{l}\mathrm{CO} \\
-- \\
\mathrm{SiC}(\mathrm{B})\end{array}$ & $\begin{array}{l}\mathrm{Fe} \\
\mathrm{Fe}(\mathrm{L}) \\
\mathrm{Fe}(\alpha, \delta, \gamma)\end{array}$ \\
\hline 1450 & $\begin{array}{l}0.01- \\
1.0\end{array}$ & $\begin{array}{l}\text { Gas } \\
\text { Liquid } \\
\text { Solid }\end{array}$ & $\begin{array}{l}\mathrm{SiO} \\
\mathrm{Si}(\mathrm{L}) \\
\mathrm{Si}(\mathrm{S}), \mathrm{Si}_{3} \mathrm{~N}_{4}(\mathrm{~A})\end{array}$ & $\begin{array}{l}\mathrm{BO} \\
\mathrm{B}(\mathrm{L}) \\
\mathrm{BN}(\mathrm{cr})\end{array}$ & $\begin{array}{l}\mathrm{PN} \\
\mathrm{P}(\mathrm{L}) \\
\mathrm{P}(\mathrm{cr})\end{array}$ & $\begin{array}{l}\mathrm{CO} \\
- \\
\mathrm{SiC}(\mathrm{B})\end{array}$ & $\begin{array}{l}\mathrm{Fe} \\
\mathrm{Fe}(\mathrm{L}) \\
\mathrm{Fe}(\alpha, \delta, \gamma)\end{array}$ \\
\hline 1550 & 0.001 & $\begin{array}{l}\text { Gas } \\
\text { Liquid } \\
\text { Solid }\end{array}$ & $\begin{array}{l}\mathrm{SiO} \\
\mathrm{Si}(\mathrm{L}) \\
\mathrm{Si}(\mathrm{S})\end{array}$ & $\begin{array}{l}\mathrm{BO} \\
\mathrm{B}(\mathrm{L}) \\
\mathrm{BN}(\mathrm{cr})\end{array}$ & $\begin{array}{l}\mathrm{PN} \\
\mathrm{P}(\mathrm{L}) \\
\mathrm{P}(\mathrm{cr})\end{array}$ & $\begin{array}{l}\mathrm{CO} \\
- \\
\mathrm{SiC}(\mathrm{B})\end{array}$ & $\begin{array}{l}\mathrm{Fe} \\
\mathrm{Fe}(\mathrm{L}) \\
\mathrm{Fe}(\alpha, \delta, \gamma)\end{array}$ \\
\hline 1550 & $\begin{array}{l}0.01- \\
1.0\end{array}$ & $\begin{array}{l}\text { Gas } \\
\text { Liquid } \\
\text { Solid } \\
\end{array}$ & $\begin{array}{l}\mathrm{SiO} \\
\mathrm{Si}(\mathrm{L}) \\
\mathrm{Si}(\mathrm{S}), \mathrm{Si}_{3} \mathrm{~N}_{4}(\mathrm{~A})\end{array}$ & $\begin{array}{l}\mathrm{BO} \\
\mathrm{B}(\mathrm{L}) \\
\mathrm{BN}(\mathrm{cr})\end{array}$ & $\begin{array}{l}\mathrm{PN} \\
\mathrm{P}(\mathrm{L}) \\
\mathrm{P}(\mathrm{cr})\end{array}$ & $\begin{array}{l}\mathrm{CO} \\
- \\
\mathrm{SiC}(\mathrm{B})\end{array}$ & $\begin{array}{l}\mathrm{Fe} \\
\mathrm{Fe}(\mathrm{L}) \\
\mathrm{Fe}(\alpha, \delta, \gamma)\end{array}$ \\
\hline 1650 & 0.001 & $\begin{array}{l}\text { Gas } \\
\text { Liquid } \\
\text { Solid }\end{array}$ & $\begin{array}{l}\mathrm{SiO} \\
\mathrm{Si}(\mathrm{L}) \\
\mathrm{Si}(\mathrm{S}), \mathrm{SiC}(\mathrm{B}) \\
\end{array}$ & $\begin{array}{l}\mathrm{BO} \\
\mathrm{B}(\mathrm{L}) \\
\mathrm{BN}(\mathrm{cr}), \mathrm{B}(\mathrm{S})\end{array}$ & $\begin{array}{l}\mathrm{PN} \\
\mathrm{P}(\mathrm{L}) \\
\mathrm{P}(\mathrm{cr})\end{array}$ & $\begin{array}{l}\mathrm{CO} \\
-- \\
\mathrm{SiC}(\mathrm{B})\end{array}$ & $\begin{array}{l}\mathrm{Fe} \\
\mathrm{Fe}(\mathrm{L}) \\
\mathrm{Fe}(\alpha, \delta, \gamma)\end{array}$ \\
\hline 1650 & 0.01 & $\begin{array}{l}\text { Gas } \\
\text { Liquid } \\
\text { Solid }\end{array}$ & $\begin{array}{l}\mathrm{SiO} \\
\mathrm{Si}(\mathrm{L}) \\
\mathrm{Si}(\mathrm{S}), \mathrm{SiC}(\mathrm{B})\end{array}$ & $\begin{array}{l}\mathrm{BO} \\
\mathrm{B}(\mathrm{L}) \\
\mathrm{BN}(\mathrm{cr})\end{array}$ & $\begin{array}{l}\mathrm{PN} \\
\mathrm{P}(\mathrm{L}) \\
\mathrm{P}(\mathrm{cr})\end{array}$ & $\begin{array}{l}\mathrm{CO} \\
- \\
\mathrm{SiC}(\mathrm{B})\end{array}$ & $\begin{array}{l}\mathrm{Fe} \\
\mathrm{Fe}(\mathrm{L}) \\
\mathrm{Fe}(\alpha, \delta, \gamma)\end{array}$ \\
\hline 1650 & $\begin{array}{l}0.1- \\
1.0\end{array}$ & $\begin{array}{l}\text { Gas } \\
\text { Liquid } \\
\text { Solid }\end{array}$ & $\begin{array}{l}\mathrm{SiO} \\
\mathrm{Si}(\mathrm{L}) \\
\mathrm{Si}_{3} \mathrm{~N}_{4}(\mathrm{~A}), \mathrm{Si}(\mathrm{S})\end{array}$ & $\begin{array}{l}\mathrm{BO} \\
\mathrm{B}(\mathrm{L}) \\
\mathrm{BN}(\mathrm{cr})\end{array}$ & $\begin{array}{l}\mathrm{PN} \\
\mathrm{P}(\mathrm{L}) \\
\mathrm{P}(\mathrm{cr})\end{array}$ & $\begin{array}{l}\mathrm{CO} \\
- \\
\mathrm{SiC}(\mathrm{B})\end{array}$ & $\begin{array}{l}\mathrm{Fe} \\
\mathrm{Fe}(\mathrm{L}) \\
\mathrm{Fe}(\alpha, \delta, \gamma)\end{array}$ \\
\hline
\end{tabular}

* Chemical species are listed for each phase in order of decreasing mole fraction as a function of temperature and pressure. If multiple species are listed, each represents at least $\sim 20 \%$ of the element in that phase. 


\section{Water Addition}

Water vapor is generally considered more reactive than $\mathrm{O}_{2}$ in terms of kinetics. From an equilibrium point of view, the presence of hydrogen allows the formation of additional compounds that may offer routes to impurity removal. Figure 7 through Figure 9 and Table 6 give the equilibrium results for reaction of the silicon/impurities mixture with water vapor. Some of the differences between the results obtained for water and oxygen result from the fact that one mole of water provides one mole of oxygen atoms whereas one mole of $\mathrm{O}_{2}$ provides two moles of oxygen atoms. The most interesting difference between water and oxygen, however, is the formation of noticeable amounts of HBO in the gas phase with water. There are also some differences in the identities of the gas-phase phosphorus-containing species, but these are present in negligible quantities. Thus, water vapor appears to be roughly comparable to oxygen from the standpoint of $\mathrm{C}$ removal, but has potential for $\mathrm{B}$ removal also. 

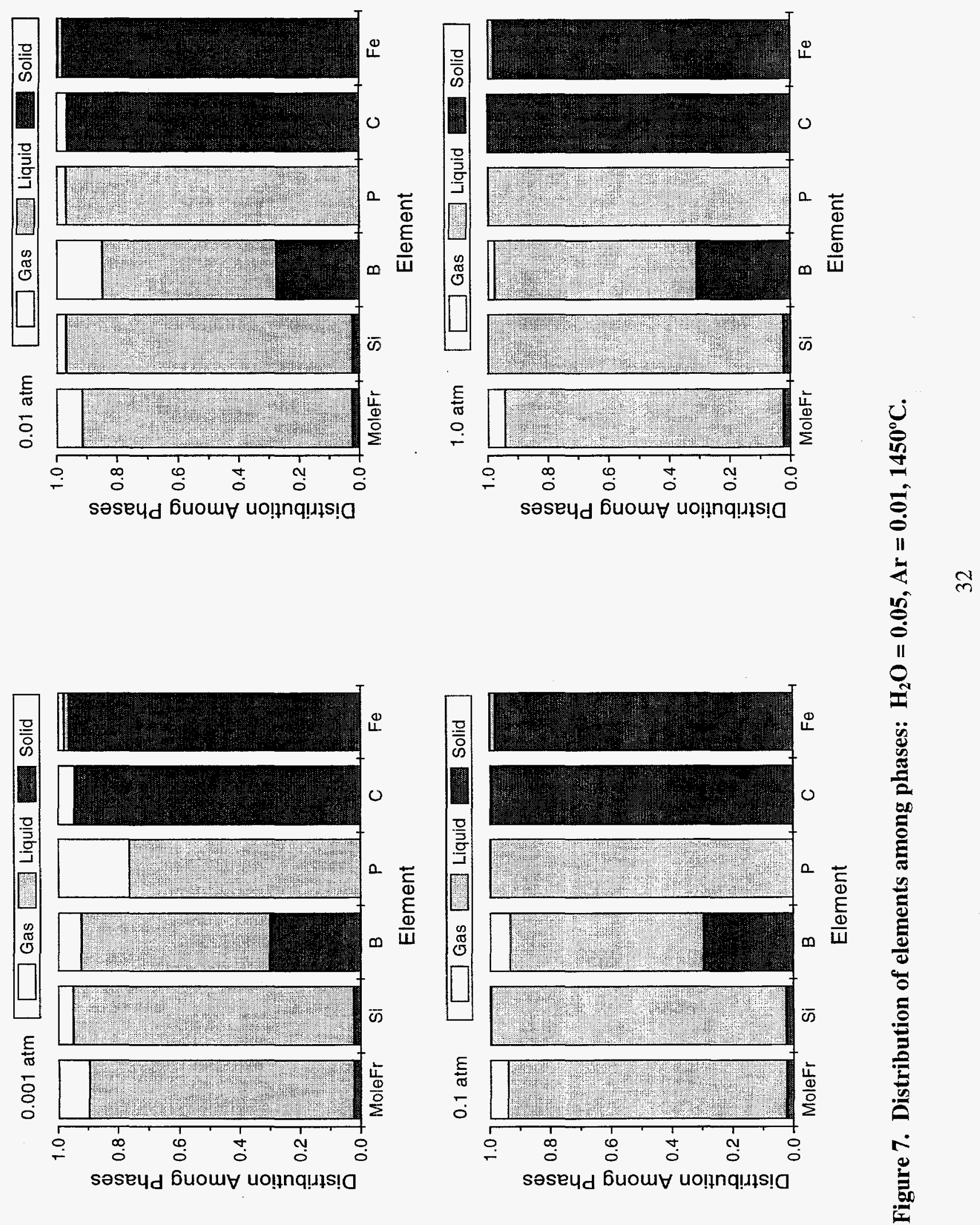

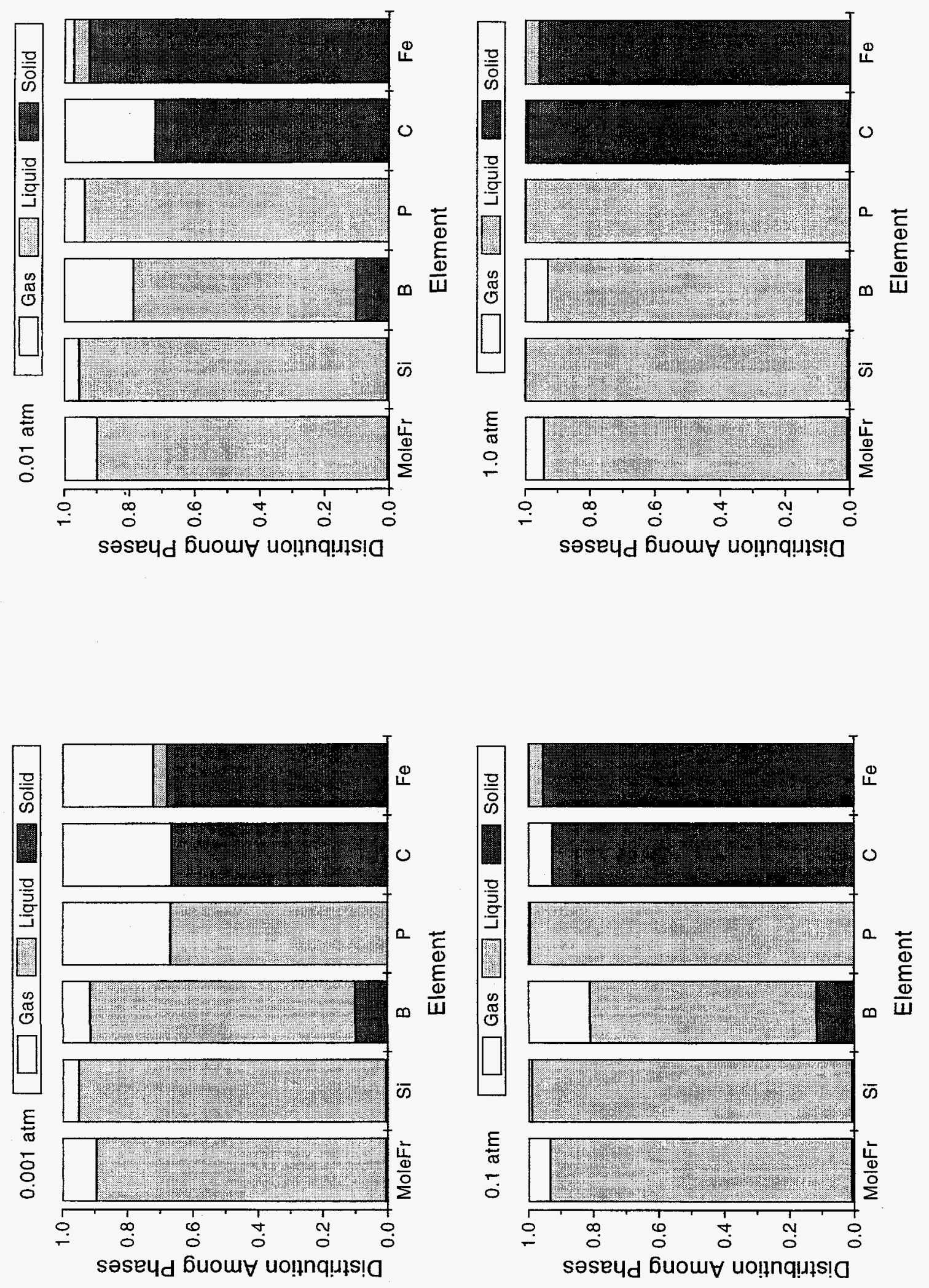

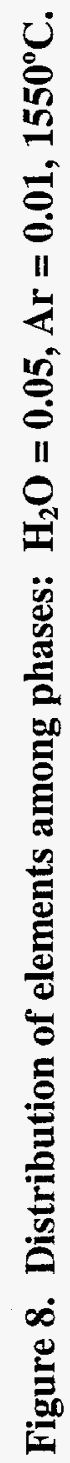



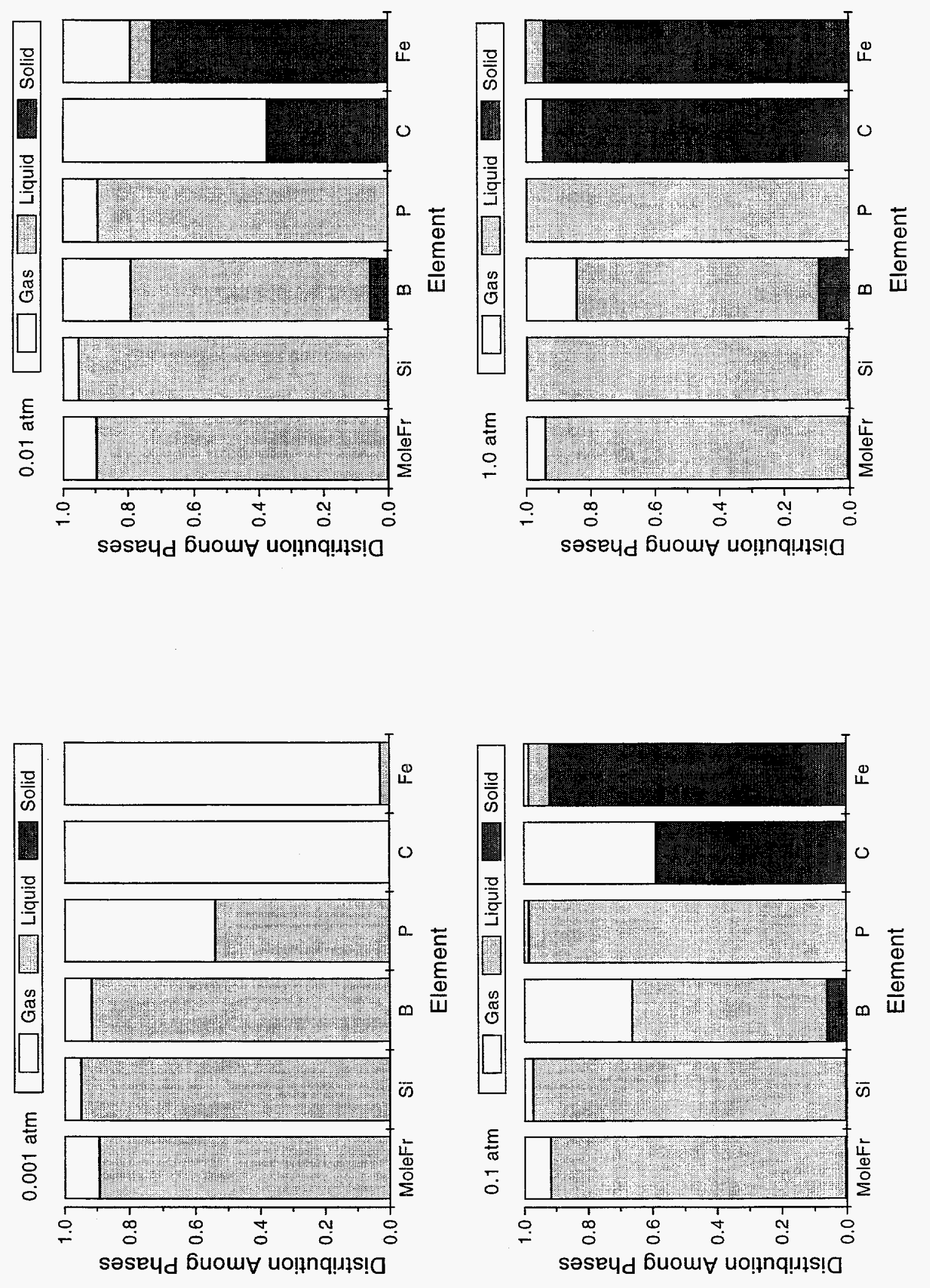

范 
Table 6. Dominant* chemical species for silicon and impurities with $\mathrm{H}_{2} \mathrm{O} / \mathrm{Ar}$ addition.

\begin{tabular}{|c|c|c|c|c|c|c|c|}
\hline $\begin{array}{l}\text { Temp. } \\
\left({ }^{\circ} \mathrm{C}\right)\end{array}$ & $\begin{array}{l}\text { Pressure } \\
\text { (atm) }\end{array}$ & Phase & $\mathrm{Si}$ & B & $P$ & C & $\mathrm{Fe}$ \\
\hline 1450 & $\begin{array}{l}0.001- \\
0.1\end{array}$ & $\begin{array}{l}\text { Gas } \\
\text { Liquid } \\
\text { Solid }\end{array}$ & $\begin{array}{l}\mathrm{SiO} \\
\mathrm{Si}(\mathrm{L}) \\
\mathrm{Si}(\mathrm{S})\end{array}$ & $\begin{array}{l}\text { HBO } \\
\text { B(L) } \\
\text { B(S) }\end{array}$ & $\begin{array}{l}\mathrm{P}_{2} \\
\mathrm{P}(\mathrm{L}) \\
\mathrm{P}(\mathrm{cr})\end{array}$ & $\begin{array}{l}\mathrm{CO} \\
-- \\
\mathrm{SiC}(\mathrm{B})\end{array}$ & $\begin{array}{l}\mathrm{Fe} \\
\mathrm{Fe}(L) \\
\mathrm{Fe}(\alpha, \delta, \gamma)\end{array}$ \\
\hline 1450 & 1.0 & $\begin{array}{l}\text { Gas } \\
\text { Liquid } \\
\text { Solid }\end{array}$ & $\begin{array}{l}\mathrm{SiO} \\
\mathrm{Si}(\mathrm{L}) \\
\mathrm{Si}(\mathrm{S})\end{array}$ & $\begin{array}{l}\mathrm{HBO} \\
\mathrm{B}(\mathrm{L}) \\
\mathrm{B}(\mathrm{S})\end{array}$ & $\begin{array}{l}\mathrm{P}_{2}, \mathrm{PH}_{3} \\
\mathrm{P}(\mathrm{L}) \\
\mathrm{P}(\mathrm{cr})\end{array}$ & $\begin{array}{l}\mathrm{CO} \\
- \\
\mathrm{SiC}(\mathrm{B})\end{array}$ & $\begin{array}{l}\mathrm{Fe} \\
\mathrm{Fe}(\mathrm{L}) \\
\mathrm{Fe}(\alpha, \delta, \gamma)\end{array}$ \\
\hline 1550 & 0.001 & $\begin{array}{l}\text { Gas } \\
\text { Liquid } \\
\text { Solid }\end{array}$ & $\begin{array}{l}\mathrm{SiO} \\
\mathrm{Si}(\mathrm{L}) \\
\mathrm{Si}(\mathrm{S})\end{array}$ & $\begin{array}{l}\mathrm{HBO} \\
\mathrm{B}(\mathrm{L}) \\
\mathrm{B}(\mathrm{S}) \\
\end{array}$ & $\begin{array}{l}\mathrm{P}_{2}, \mathrm{P} \\
\mathrm{P}(\mathrm{L}) \\
\mathrm{P}(\mathrm{cr})\end{array}$ & $\begin{array}{l}\mathrm{CO} \\
-- \\
\mathrm{SiC}(\mathrm{B}) \\
\end{array}$ & $\begin{array}{l}\mathrm{Fe} \\
\mathrm{Fe}(\mathrm{L}) \\
\mathrm{Fe}(\alpha, \delta, \gamma)\end{array}$ \\
\hline 1550 & 0.01 & $\begin{array}{l}\text { Gas } \\
\text { Liquid } \\
\text { Solid } \\
\end{array}$ & $\begin{array}{l}\mathrm{SiO} \\
\mathrm{Si}(\mathrm{L}) \\
\mathrm{Si}(\mathrm{S}) \\
\end{array}$ & $\begin{array}{l}\text { HBO } \\
\mathrm{B}(\mathrm{L}) \\
\mathrm{B}(\mathrm{S}) \\
\end{array}$ & $\begin{array}{l}\mathrm{P}_{2} \\
\mathrm{P}(\mathrm{L}) \\
\mathrm{P}(\mathrm{cr}) \\
\end{array}$ & $\begin{array}{l}\mathrm{CO} \\
- \\
\mathrm{SiC}(\mathrm{B})\end{array}$ & $\begin{array}{l}\mathrm{Fe} \\
\mathrm{Fe}(\mathrm{L}) \\
\mathrm{Fe}(\alpha, \delta, \gamma)\end{array}$ \\
\hline 1550 & 0.1 & $\begin{array}{l}\text { Gas } \\
\text { Liquid } \\
\text { Solid }\end{array}$ & $\begin{array}{l}\mathrm{SiO} \\
\mathrm{Si}(\mathrm{L}) \\
\mathrm{Si}(\mathrm{S})\end{array}$ & $\begin{array}{l}\mathrm{HBO} \\
\mathrm{B}(\mathrm{L}) \\
\mathrm{B}(\mathrm{S})\end{array}$ & $\begin{array}{l}\mathrm{P}_{2}, \text { CHP } \\
\mathrm{P}(\mathrm{L}) \\
\mathrm{P}(\mathrm{cr})\end{array}$ & $\begin{array}{l}\mathrm{CO} \\
-- \\
\mathrm{SiC}(\mathrm{B}) \\
\end{array}$ & $\begin{array}{l}\mathrm{Fe} \\
\mathrm{Fe}(\mathrm{L}) \\
\mathrm{Fe}(\alpha, \delta, \gamma)\end{array}$ \\
\hline 1550 & 1.0 & $\begin{array}{l}\text { Gas } \\
\text { Liquid } \\
\text { Solid } \\
\end{array}$ & $\begin{array}{l}\mathrm{SiO} \\
\mathrm{Si}(\mathrm{L}) \\
\mathrm{Si}(\mathrm{S}) \\
\end{array}$ & $\begin{array}{l}\text { HBO } \\
\text { B(L) } \\
\text { B(S) } \\
\end{array}$ & $\begin{array}{l}\text { CHP, } \mathrm{P}_{2} \\
\mathrm{P}(\mathrm{L}) \\
\mathrm{P}(\mathrm{cr}) \\
\end{array}$ & $\begin{array}{l}\mathrm{CO} \\
- \\
\mathrm{SiC}(\mathrm{B}) \\
\end{array}$ & $\begin{array}{l}\mathrm{Fe} \\
\mathrm{Fe}(\mathrm{L}) \\
\mathrm{Fe}(\alpha, \delta, \gamma)\end{array}$ \\
\hline 1650 & 0.001 & $\begin{array}{l}\text { Gas } \\
\text { Liquid } \\
\text { Solid } \\
\end{array}$ & $\begin{array}{l}\mathrm{SiO} \\
\mathrm{Si}(\mathrm{L}) \\
-- \\
\end{array}$ & $\begin{array}{l}\mathrm{HBO} \\
\mathrm{B}(\mathrm{L}) \\
-- \\
\end{array}$ & $\begin{array}{l}\mathrm{P}_{2}, \mathrm{P} \\
\mathrm{P}(\mathrm{L}) \\
--\end{array}$ & $\begin{array}{l}\mathrm{CO} \\
-- \\
- \\
\end{array}$ & $\begin{array}{l}\mathrm{Fe} \\
\mathrm{Fe}(\mathrm{L}) \\
-- \\
\end{array}$ \\
\hline 1650 & 0.01 & $\begin{array}{l}\text { Gas } \\
\text { Liquid } \\
\text { Solid }\end{array}$ & $\begin{array}{l}\mathrm{SiO} \\
\mathrm{Si}(\mathrm{L}) \\
\mathrm{Si}(\mathrm{S}) \\
\end{array}$ & $\begin{array}{l}\mathrm{HBO} \\
\mathrm{B}(\mathrm{L}) \\
\mathrm{B}(\mathrm{S}) \\
\end{array}$ & $\begin{array}{l}\mathrm{P}_{2}, \mathrm{P} \\
\mathrm{P}(\mathrm{L}) \\
\mathrm{P}(\mathrm{cr}) \\
\end{array}$ & $\begin{array}{l}\mathrm{CO} \\
-- \\
\mathrm{SiC}(\mathrm{B}) \\
\end{array}$ & $\begin{array}{l}\mathrm{Fe} \\
\mathrm{Fe}(\mathrm{L}) \\
\mathrm{Fe}(\alpha, \delta, \gamma)\end{array}$ \\
\hline 1650 & 0.1 & $\begin{array}{l}\text { Gas } \\
\text { Liquid } \\
\text { Solid }\end{array}$ & $\begin{array}{l}\mathrm{SiO} \\
\mathrm{Si}(\mathrm{L}) \\
\mathrm{Si}(\mathrm{S})\end{array}$ & $\begin{array}{l}\mathrm{HBO} \\
\mathrm{B}(\mathrm{L}) \\
\mathrm{B}(\mathrm{S})\end{array}$ & $\begin{array}{l}\mathrm{P}_{2}, \text { CHP } \\
\mathrm{P}(\mathrm{L}) \\
\mathrm{P}(\mathrm{cr})\end{array}$ & $\begin{array}{l}\mathrm{CO} \\
- \\
\mathrm{SiC}(\mathrm{B})\end{array}$ & $\begin{array}{l}\mathrm{Fe} \\
\mathrm{Fe}(\mathrm{L}) \\
\mathrm{Fe}(\alpha, \delta, \gamma)\end{array}$ \\
\hline 1650 & 1.0 & $\begin{array}{l}\text { Gas } \\
\text { Liquid } \\
\text { Solid }\end{array}$ & $\begin{array}{l}\mathrm{SiO} \\
\mathrm{Si}(\mathrm{L}) \\
\mathrm{Si}(\mathrm{S}), \mathrm{SiC}(\mathrm{B})\end{array}$ & $\begin{array}{l}\text { HBO } \\
\mathrm{B}(\mathrm{L}) \\
\mathrm{B}(\mathrm{S}) \\
\end{array}$ & $\begin{array}{l}\text { CHP } \\
\mathrm{P}(\mathrm{L}) \\
\mathrm{P}(\mathrm{cr}) \\
\end{array}$ & $\begin{array}{l}\mathrm{CO} \\
-- \\
\mathrm{SiC}(\mathrm{B}) \\
\end{array}$ & $\begin{array}{l}\mathrm{Fe} \\
\mathrm{Fe}(\mathrm{L}) \\
\mathrm{Fe}(\alpha, \delta, \gamma)\end{array}$ \\
\hline
\end{tabular}

* Chemical species are listed for each phase in order of decreasing mole fraction as a function of temperature and pressure. If multiple species are listed, each represents at least $\sim 20 \%$ of the element in that phase. 


\section{Wet Air Addition}

Using a combination of water vapor (20\%) and air gives the results shown in Figure 10 through Figure 12 and Table 7. The results in these figures are very similar to those shown in section III.B. above for air. Although the presence of the water vapor leads to the formation of HBO rather than $\mathrm{BO}$ in the gas phase, this is a relatively small effect. Under most of the conditions, the boron is $\mathrm{BN}(\mathrm{cr})$ formed by reaction with $\mathrm{N}_{2}$. From a thermodynamic viewpoint, wet air offers only a small advantage for boron removal over dry air, but there may be kinetic advantages that are not addressed here. 

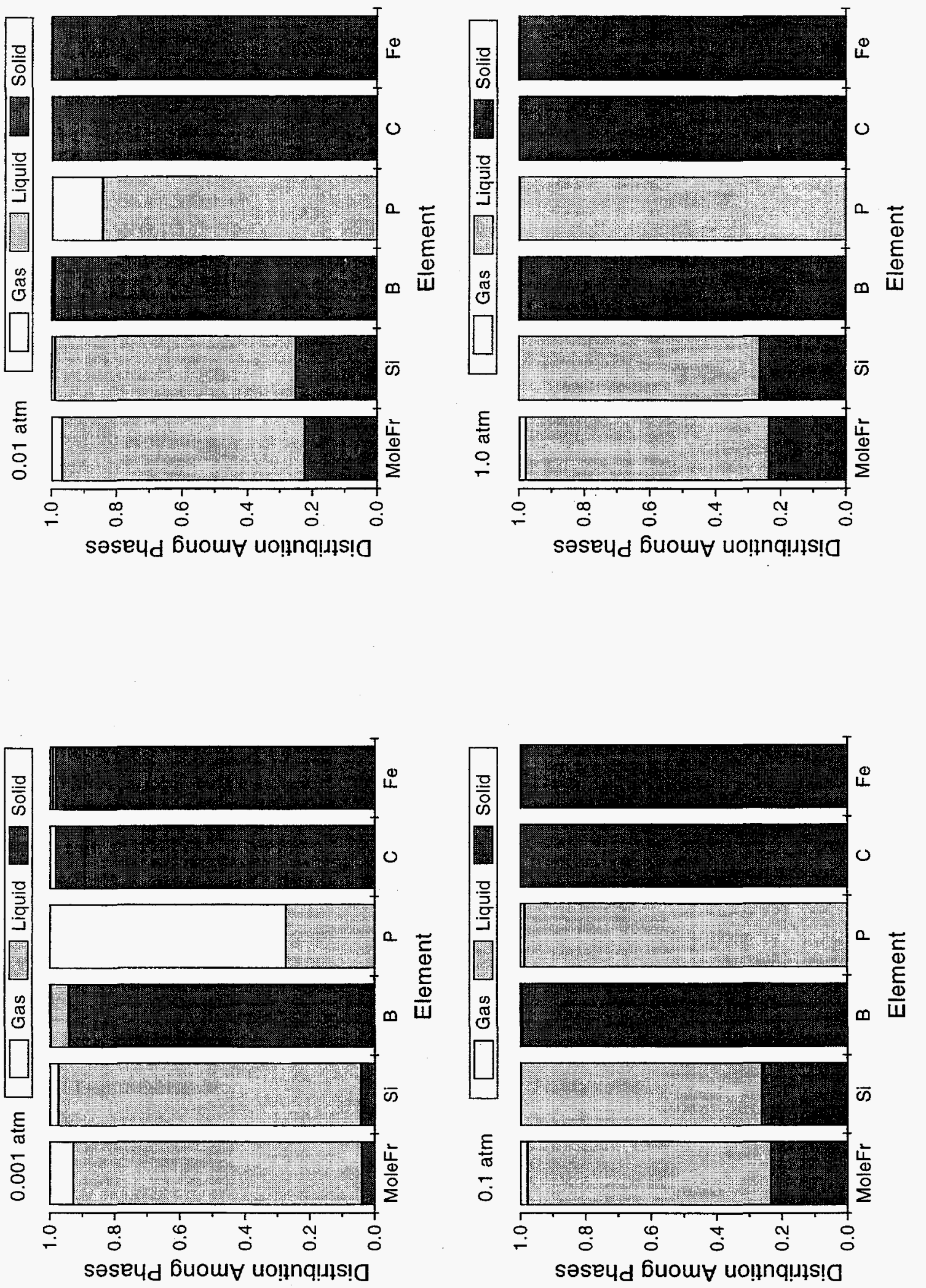

ن 

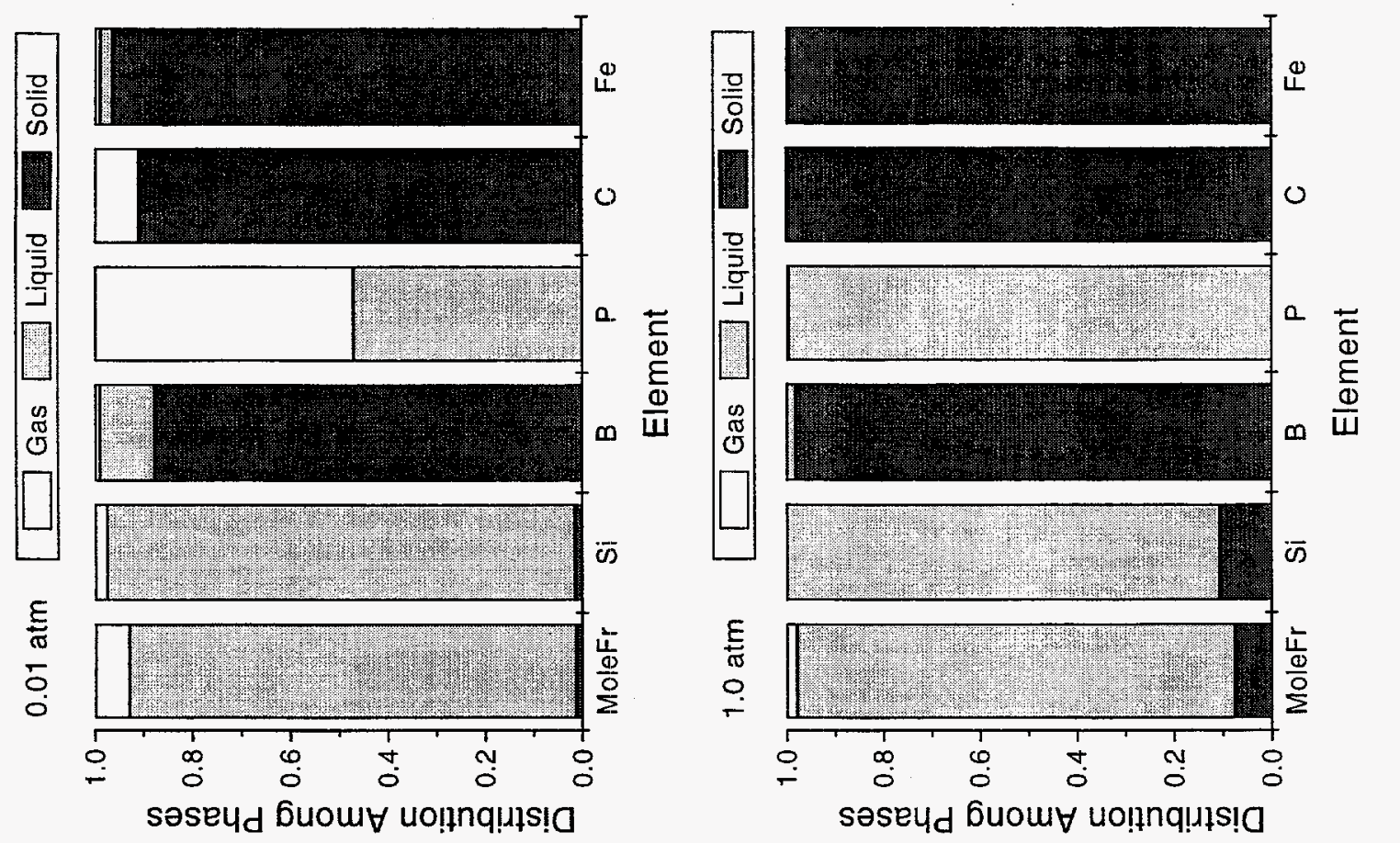

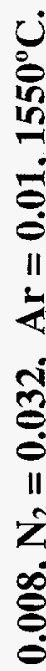
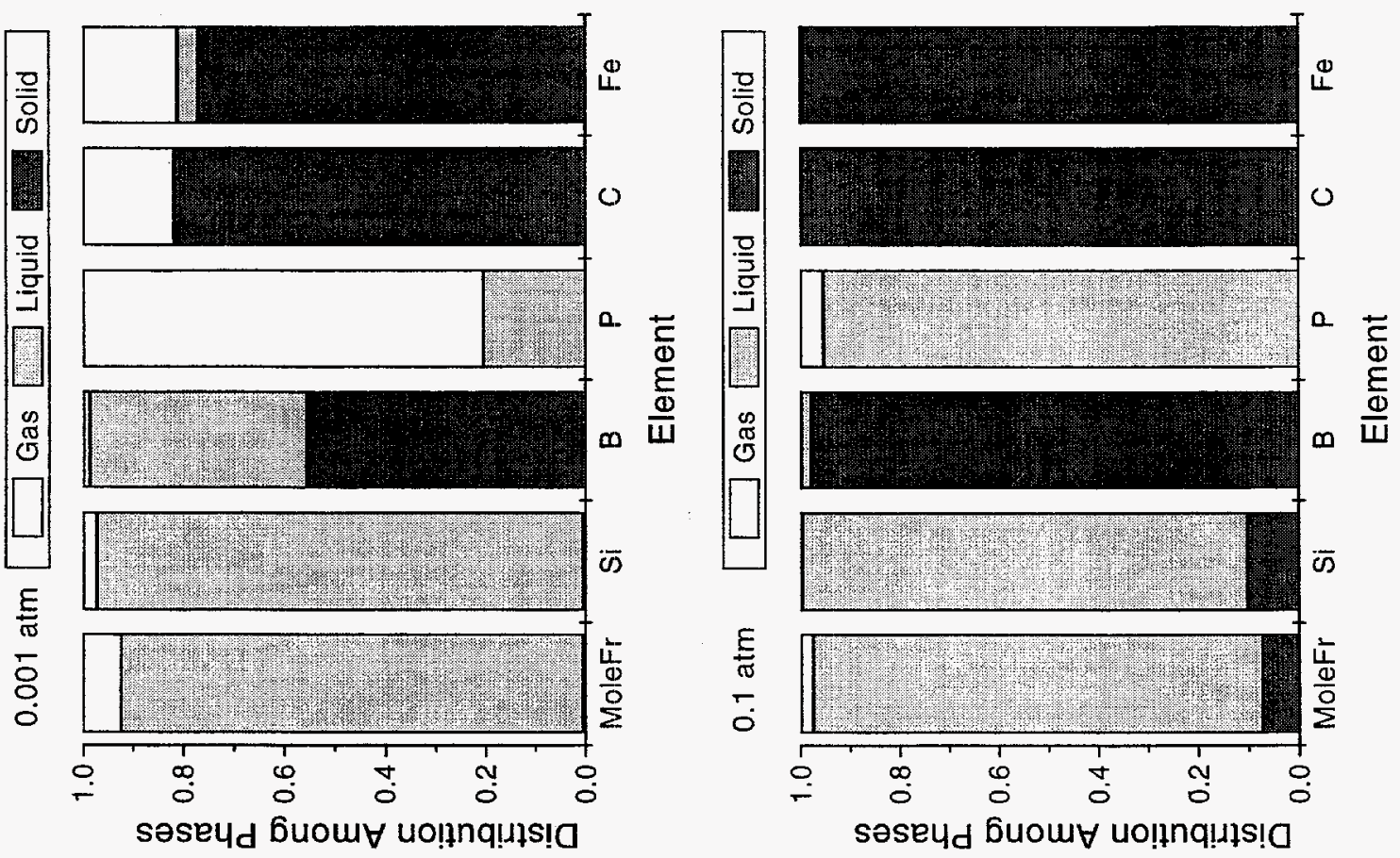

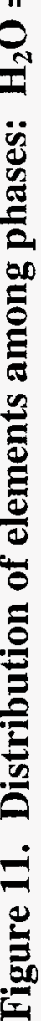



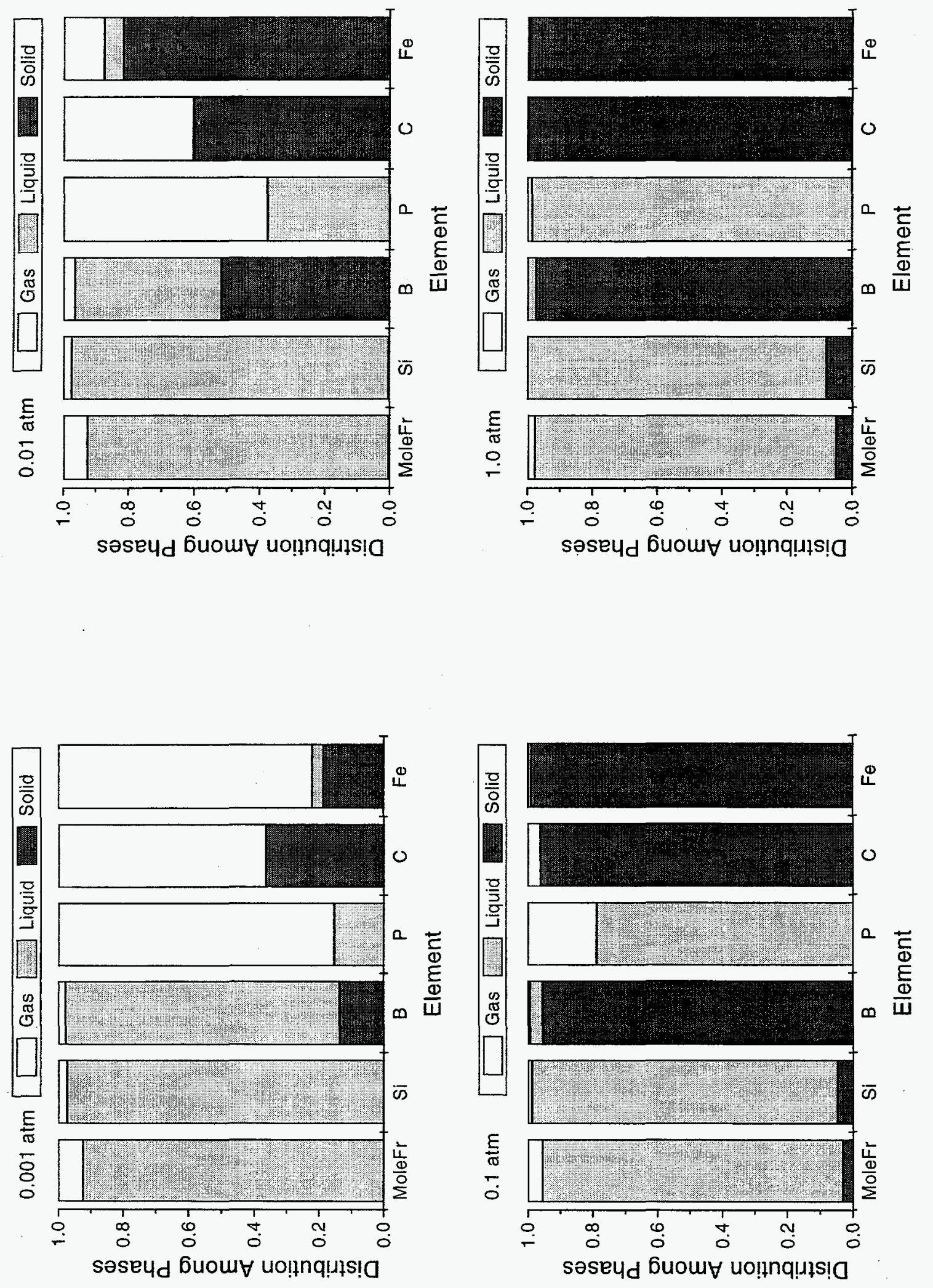

ن 
Table 7. Dominant* chemical species for silicon and impurities with $\mathrm{H}_{2} \mathrm{O} / \mathrm{O}_{2} / \mathrm{N}_{2} / \mathrm{Ar}$ addition.

\begin{tabular}{|c|c|c|c|c|c|c|c|}
\hline $\begin{array}{l}\text { Temp. } \\
\left({ }^{\circ} \mathrm{C}\right)\end{array}$ & $\begin{array}{l}\text { Pressure } \\
\text { (atm) }\end{array}$ & Phase & $\mathrm{Si}$ & B & $P$ & C & $\mathrm{Fe}$ \\
\hline 1450 & 0.001 & $\begin{array}{l}\text { Gas } \\
\text { Liquid } \\
\text { Solid }\end{array}$ & $\begin{array}{l}\mathrm{SiO} \\
\mathrm{Si}(\mathrm{L}) \\
\mathrm{Si}(\mathrm{S})\end{array}$ & $\begin{array}{l}\mathrm{HBO} \\
\mathrm{B}(\mathrm{L}) \\
\mathrm{BN}(\mathrm{cr})\end{array}$ & $\begin{array}{l}\mathrm{PN} \\
\mathrm{P}(\mathrm{L}) \\
\mathrm{P}(\mathrm{cr})\end{array}$ & $\begin{array}{l}\mathrm{CO} \\
-- \\
\mathrm{SiC}(\mathrm{B})\end{array}$ & $\begin{array}{l}\mathrm{Fe} \\
\mathrm{Fe}(\mathrm{L}) \\
\mathrm{Fe}(\alpha, \delta, \gamma)\end{array}$ \\
\hline 1450 & $\begin{array}{l}0.01- \\
1.0\end{array}$ & $\begin{array}{l}\text { Gas } \\
\text { Liquid } \\
\text { Solid }\end{array}$ & $\begin{array}{l}\mathrm{SiO} \\
\mathrm{Si}(\mathrm{L}) \\
\mathrm{Si}(\mathrm{S}), \mathrm{Si}_{3} \mathrm{~N}_{4}(\mathrm{~A})\end{array}$ & $\begin{array}{l}\mathrm{HBO} \\
\mathrm{B}(\mathrm{L}) \\
\mathrm{BN}(\mathrm{cr})\end{array}$ & $\begin{array}{l}\mathrm{PN} \\
\mathrm{P}(\mathrm{L}) \\
\mathrm{P}(\mathrm{cr})\end{array}$ & $\begin{array}{l}\mathrm{CO} \\
- \\
\mathrm{SiC}(\mathrm{B})\end{array}$ & $\begin{array}{l}\mathrm{Fe} \\
\mathrm{Fe}(\mathrm{L}) \\
\mathrm{Fe}(\alpha, \delta, \gamma)\end{array}$ \\
\hline 1550 & 0.001 & $\begin{array}{l}\text { Gas } \\
\text { Liquid } \\
\text { Solid } \\
\end{array}$ & $\begin{array}{l}\mathrm{SiO} \\
\mathrm{Si}(\mathrm{L}) \\
\mathrm{Si}(\mathrm{S}) \\
\end{array}$ & $\begin{array}{l}\mathrm{HBO} \\
\mathrm{B}(\mathrm{L}) \\
\mathrm{BN}(\mathrm{cr})\end{array}$ & $\begin{array}{l}\mathrm{PN} \\
\mathrm{P}(\mathrm{L}) \\
\mathrm{P}(\mathrm{cr})\end{array}$ & $\begin{array}{l}\mathrm{CO} \\
- \\
\mathrm{SiC}(\mathrm{B}) \\
\end{array}$ & $\begin{array}{l}\mathrm{Fe} \\
\mathrm{Fe}(\mathrm{L}) \\
\mathrm{Fe}(\alpha, \delta, \gamma)\end{array}$ \\
\hline 1550 & $\begin{array}{l}0.01- \\
1.0\end{array}$ & $\begin{array}{l}\text { Gas } \\
\text { Liquid } \\
\text { Solid }\end{array}$ & $\begin{array}{l}\mathrm{SiO} \\
\mathrm{Si}(\mathrm{L}) \\
\mathrm{Si}(\mathrm{S}), \mathrm{Si}_{3} \mathrm{~N}_{4}(\mathrm{~A})\end{array}$ & $\begin{array}{l}\mathrm{HBO} \\
\mathrm{B}(\mathrm{L}) \\
\mathrm{BN}(\mathrm{cr})\end{array}$ & $\begin{array}{l}\mathrm{PN} \\
\mathrm{P}(\mathrm{L}) \\
\mathrm{P}(\mathrm{cr})\end{array}$ & $\begin{array}{l}\mathrm{CO} \\
- \\
\mathrm{SiC}(\mathrm{B})\end{array}$ & $\begin{array}{l}\mathrm{Fe} \\
\mathrm{Fe}(\mathrm{L}) \\
\mathrm{Fe}(\alpha, \delta, \gamma)\end{array}$ \\
\hline 1650 & 0.001 & $\begin{array}{l}\text { Gas } \\
\text { Liquid } \\
\text { Solid }\end{array}$ & $\begin{array}{l}\mathrm{SiO} \\
\mathrm{Si}(\mathrm{L}) \\
\mathrm{Si}(\mathrm{S}), \mathrm{SiC}(\mathrm{B})\end{array}$ & $\begin{array}{l}\mathrm{HBO} \\
\mathrm{B}(\mathrm{L}) \\
\mathrm{BN}(\mathrm{cr}), \\
\mathrm{B}(\mathrm{S})\end{array}$ & $\begin{array}{l}\text { PN } \\
\text { P(L) } \\
\text { P(cr) }\end{array}$ & $\begin{array}{l}\mathrm{CO} \\
- \\
\mathrm{SiC}(\mathrm{B})\end{array}$ & $\begin{array}{l}\mathrm{Fe} \\
\mathrm{Fe}(\mathrm{L}) \\
\mathrm{Fe}(\alpha, \delta, \gamma)\end{array}$ \\
\hline 1650 & 0.01 & $\begin{array}{l}\text { Gas } \\
\text { Liquid } \\
\text { Solid } \\
\end{array}$ & $\begin{array}{l}\mathrm{SiO} \\
\mathrm{Si}(\mathrm{L}) \\
\mathrm{Si}(\mathrm{S}), \mathrm{SiC}(\mathrm{B}) \\
\end{array}$ & $\begin{array}{l}\mathrm{HBO} \\
\mathrm{B}(\mathrm{L}) \\
\mathrm{BN}(\mathrm{cr}) \\
\end{array}$ & $\begin{array}{l}\mathrm{PN} \\
\mathrm{P}(\mathrm{L}) \\
\mathrm{P}(\mathrm{cr}) \\
\end{array}$ & $\begin{array}{l}\mathrm{CO} \\
- \\
\mathrm{SiC}(\mathrm{B}) \\
\end{array}$ & $\begin{array}{l}\mathrm{Fe} \\
\mathrm{Fe}(\mathrm{L}) \\
\mathrm{Fe}(\alpha, \delta, \gamma)\end{array}$ \\
\hline 1650 & $\begin{array}{l}0.1- \\
1.0\end{array}$ & $\begin{array}{l}\text { Gas } \\
\text { Liquid } \\
\text { Solid }\end{array}$ & $\begin{array}{l}\mathrm{SiO} \\
\mathrm{Si}(\mathrm{L}) \\
\mathrm{Si}_{3} \mathrm{~N}_{4}(\mathrm{~A}), \mathrm{Si}(\mathrm{S})\end{array}$ & $\begin{array}{l}\text { HBO } \\
\text { B(L) } \\
\text { BN(cr) }\end{array}$ & $\begin{array}{l}\mathrm{PN} \\
\mathrm{P}(\mathrm{L}) \\
\mathrm{P}(\mathrm{cr})\end{array}$ & $\begin{array}{l}\mathrm{CO} \\
-- \\
\mathrm{SiC}(\mathrm{B})\end{array}$ & $\begin{array}{l}\mathrm{Fe} \\
\mathrm{Fe}(\mathrm{L}) \\
\mathrm{Fe}(\alpha, \delta, \gamma)\end{array}$ \\
\hline
\end{tabular}

* Chemical species are listed for each phase in order of decreasing mole fraction as a function of temperature and pressure. If multiple species are listed, each represents at least $\sim 20 \%$ of the element in that phase. 


\section{E. HCI Addition}

Many of the elements of interest in this study have volatile chlorides, so the use of $\mathrm{HCl}$ for purification is worth examining. Chloride chemistry is commonly used for the production and purification of silicon, although it introduces experimental complications because of its corrosive nature. Figure 13 through Figure 15 and Table 8 give the equilibrium results for this system. In this case almost no volatile carbon compounds are formed, in sharp contrast with the oxidizing chemical systems discussed above. The carbon stays in the solid phase as silicon carbide for the entire range of conditions explored. The $\mathrm{HCl}$ system also exhibits volatile $\mathrm{Fe}$ species $\left(\mathrm{FeCl}_{2}\right)$ over a much wider range of pressure and temperature conditions than in sections III.A. - D., where Fe volatilized as the atomic vapor. In this system, there is some vaporization of phosphorus as $\mathrm{P}_{2}$, especially at high temperatures and low pressures, but no significant chemical reaction. Formation of volatile boron compounds $\left(\mathrm{BCl}, \mathrm{BCl}_{3}\right.$ and $\left.\mathrm{BHCl}_{2}\right)$, occurs to a roughly comparable extent as $\mathrm{HBO}$ formation from water. Overall, $\mathrm{HCl}$ appears to offer a good route to Fe removal, with some potential for $\mathrm{B}$ removal. $\mathrm{But} \mathrm{HCl}$ does not volatilize $\mathrm{C}$ and appears to offer no advantage over vacuum for $P$ removal. 

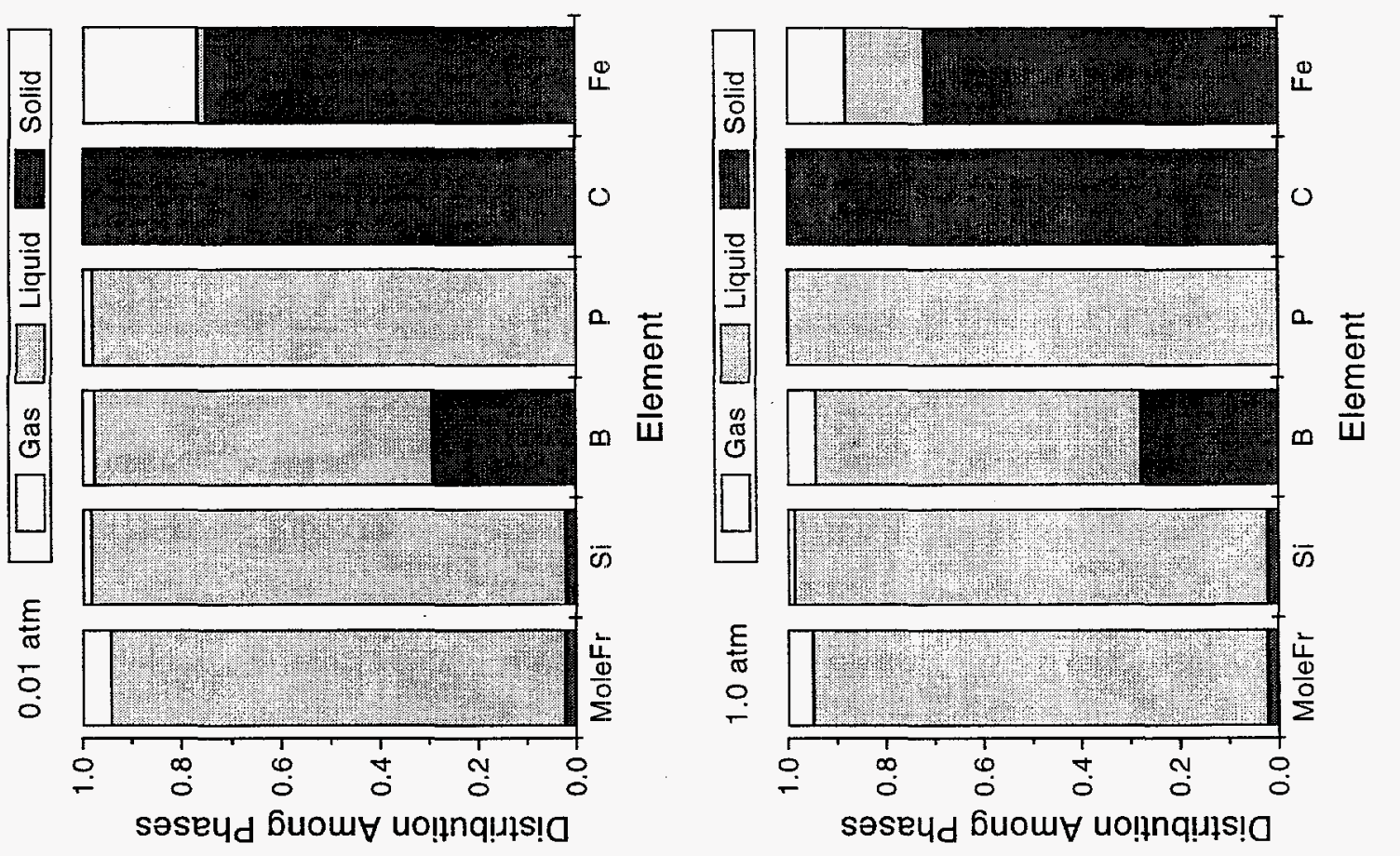

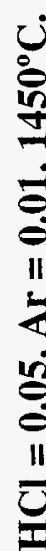
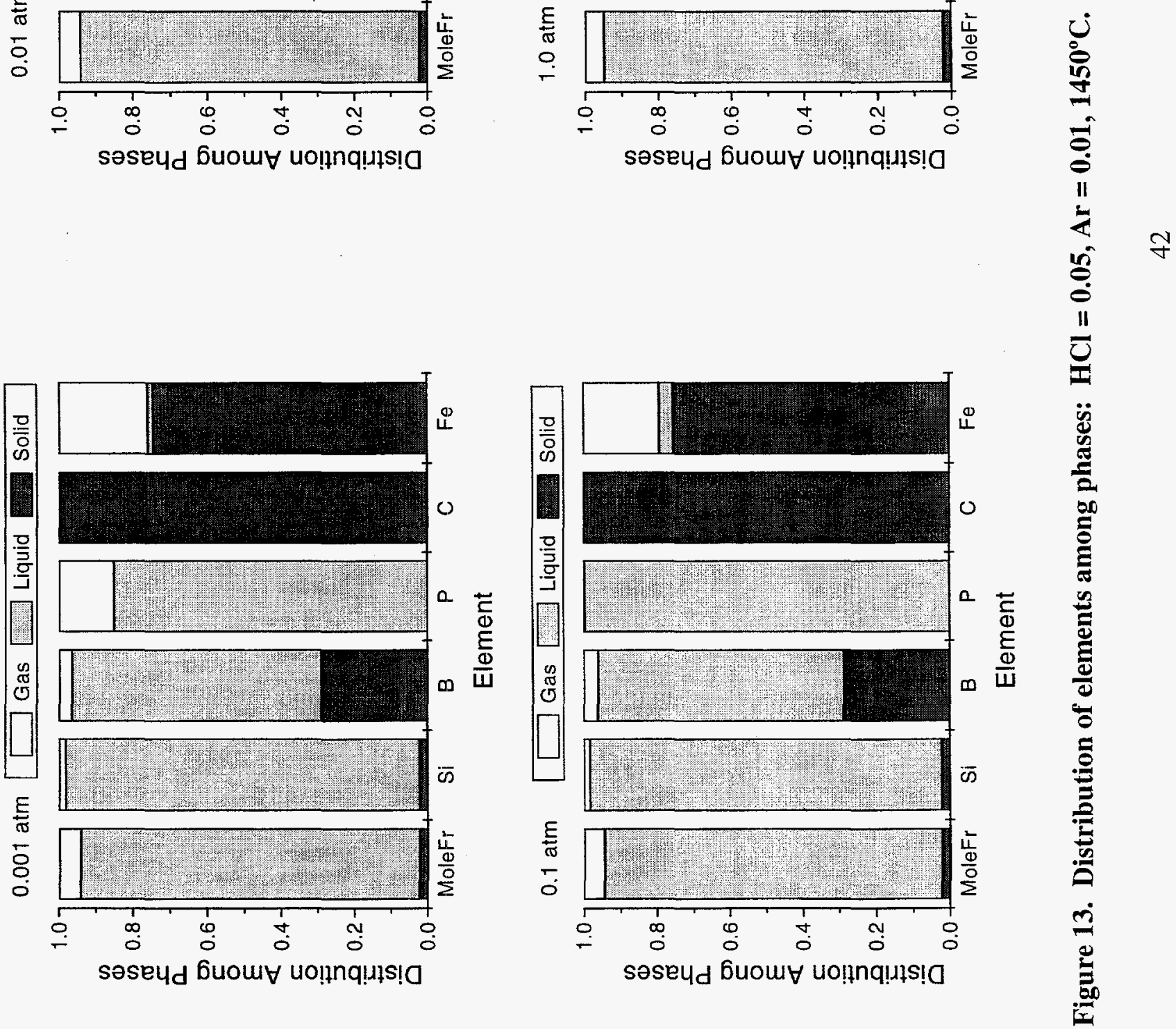

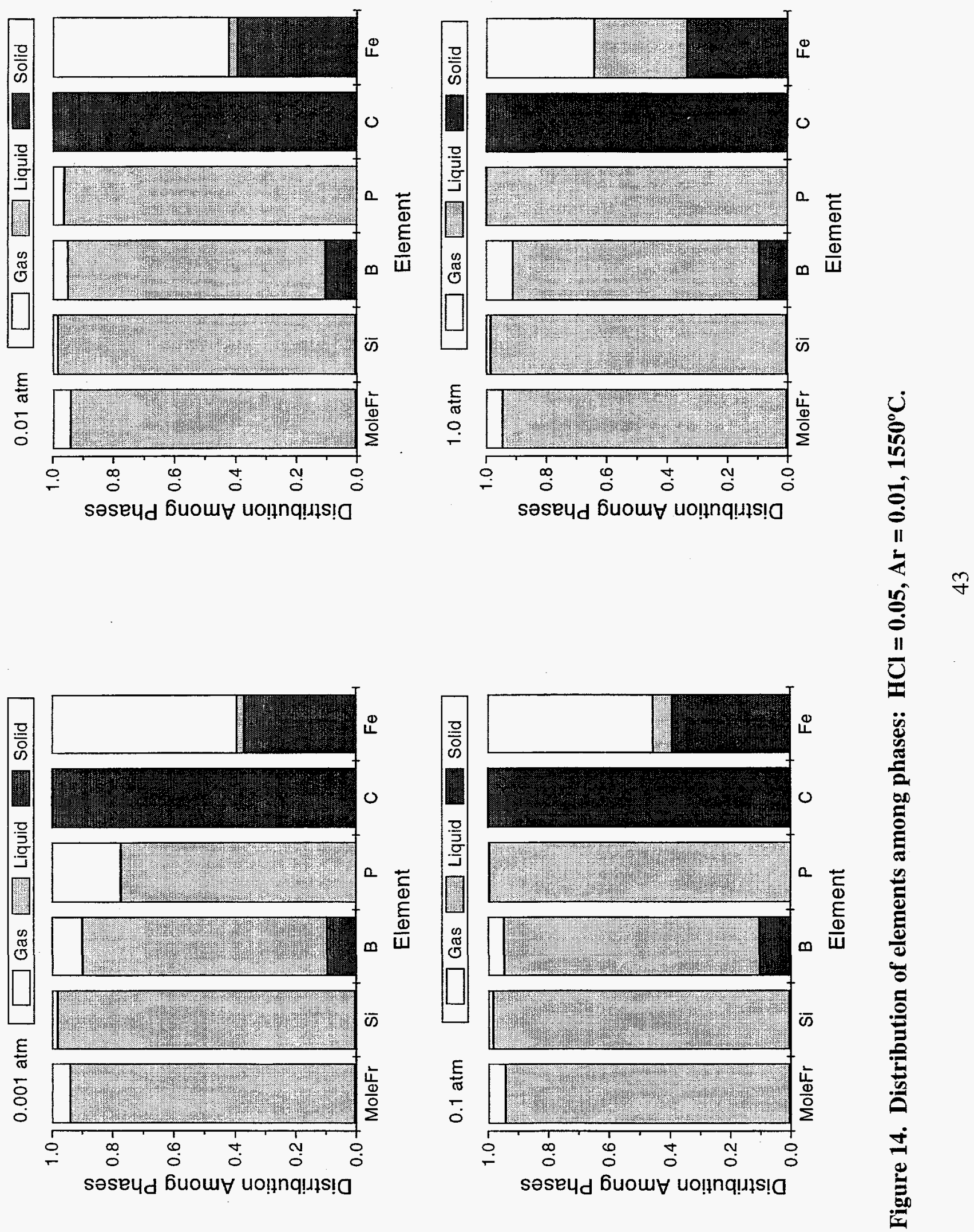

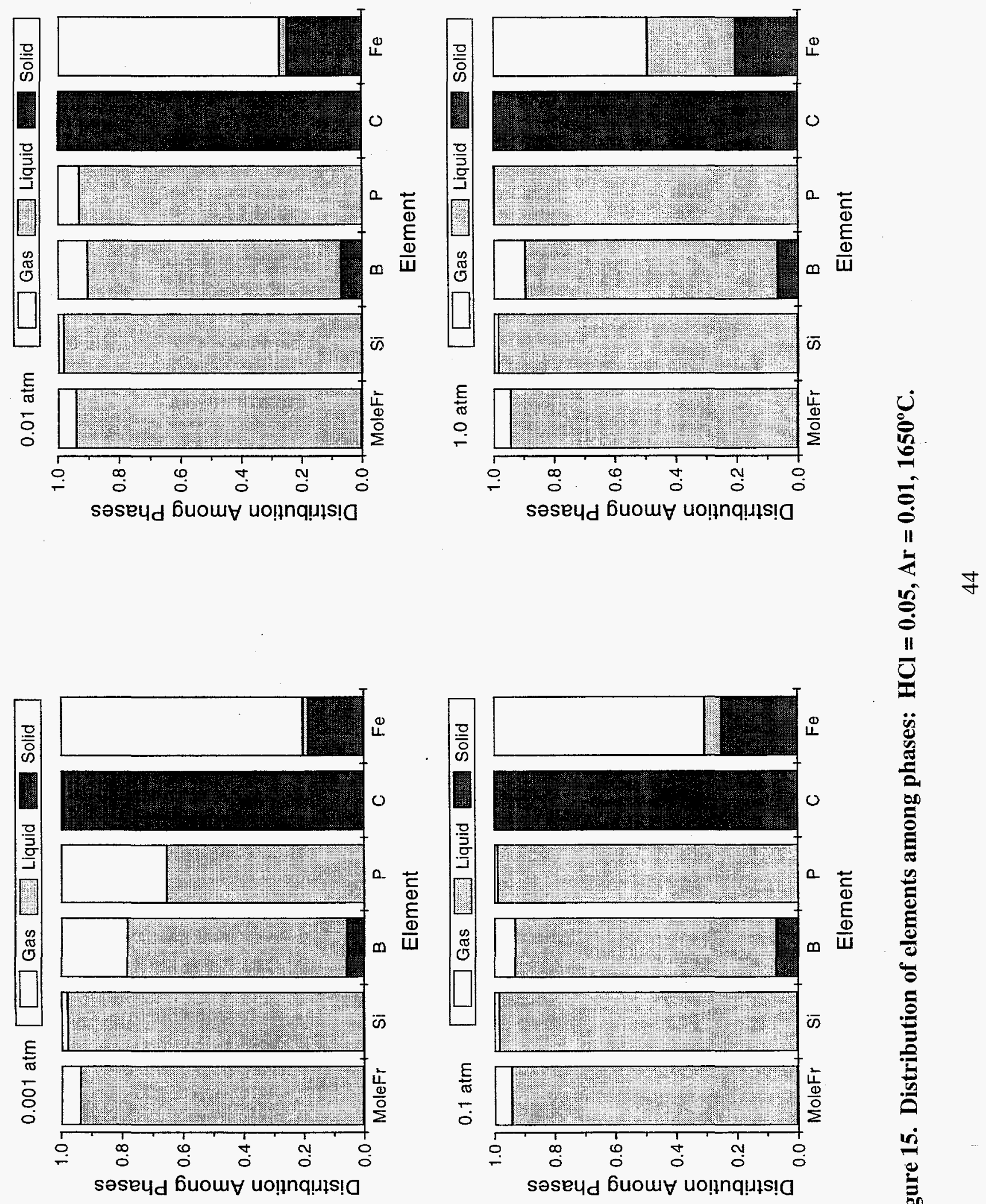

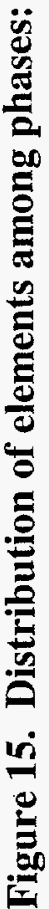




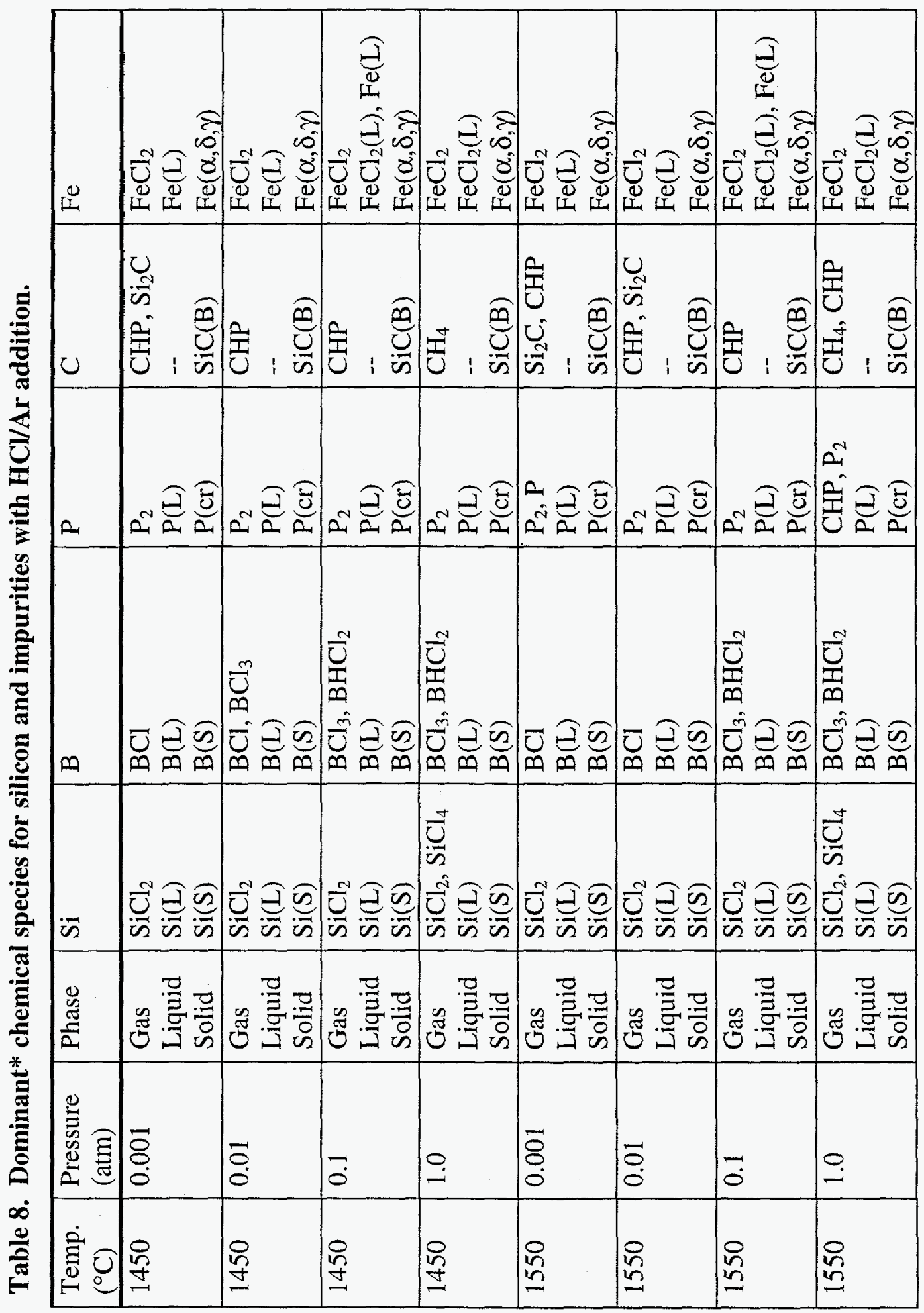




\begin{tabular}{|c|c|c|c|c|}
\hline i & 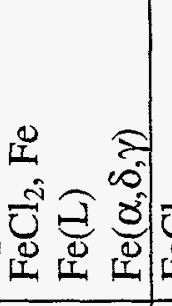 & 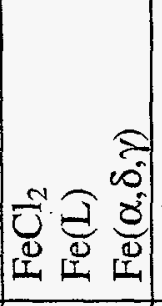 & 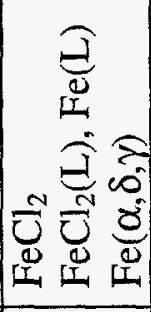 & 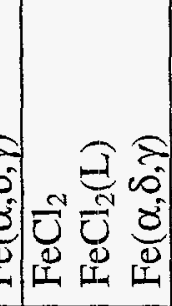 \\
\hline u & 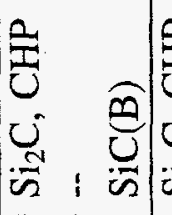 & 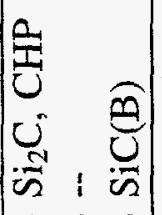 & 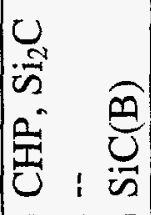 & 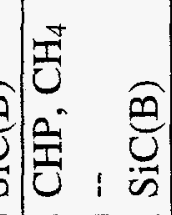 \\
\hline$\alpha$ & مu & 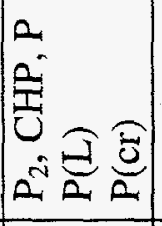 & : & 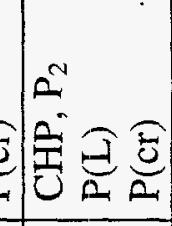 \\
\hline$\infty$ & 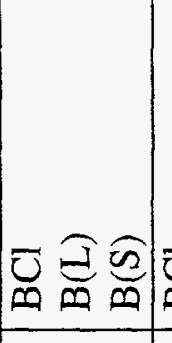 & ت্心 & 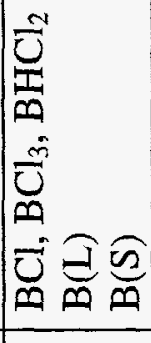 & 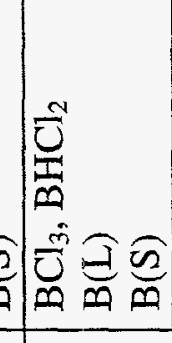 \\
\hline $\bar{n}$ & 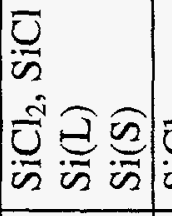 & 氙氞 & 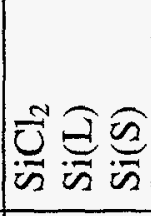 & 记 \\
\hline 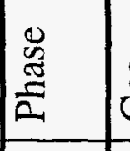 & 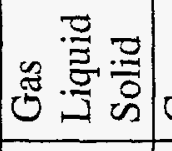 & 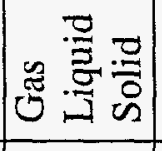 & 爱: & 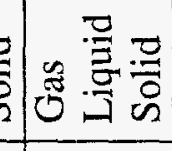 \\
\hline 這 & $\overline{0}$ & $\dot{0}$ & $\overrightarrow{0}$ & $\stackrel{\circ}{-}$ \\
\hline हี & 总 & 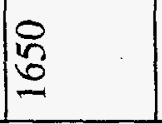 & 6 & 总 \\
\hline
\end{tabular}




\section{F. $\mathbf{C l}_{2}$ Addition}

$\mathrm{Cl}_{2}$ is an alternate source of chlorine, although experimentally it is somewhat more difficult to handle than $\mathrm{HCl}$. Each mole of chlorine gas provides twice as many chlorine atoms as a mole of $\mathrm{HCl}$, so on a "per sccm" basis, it is a more intense $\mathrm{Cl}$ source. Figure 16 through Figure 18 and Table 9 give the equilibrium results for adding $\mathrm{Cl}_{2}$ to this system. As expected, these results are quite similar to those for $\mathrm{HCl}$ addition. There is somewhat higher volatilization of $\mathrm{Fe}$ as $\mathrm{FeCl}_{2}$, $\mathrm{B}$ as $\mathrm{BCl}_{\mathrm{x}}(\mathrm{x}=1,3)$, and $\mathrm{Si}$ as $\mathrm{SiCl}_{\mathrm{x}}(\mathrm{x}=2,4)$ as a result of the higher $\mathrm{Cl}$ content of the system. The absence of $\mathrm{H}$ in the system leads to differences in the identity of some of the gas-phase species, but this is a minor effect. There is some evaporation of $\mathrm{P}$ as $\mathrm{P}_{2}$ at lower pressures and higher temperatures, but the $\mathrm{C}$ remains in the solid as silicon carbide. As for $\mathrm{HCl}, \mathrm{Cl}_{2}$ offers advantages for Fe removal and probably $\mathrm{B}$ removal, but not $\mathrm{C}$ or $\mathrm{P}$. 

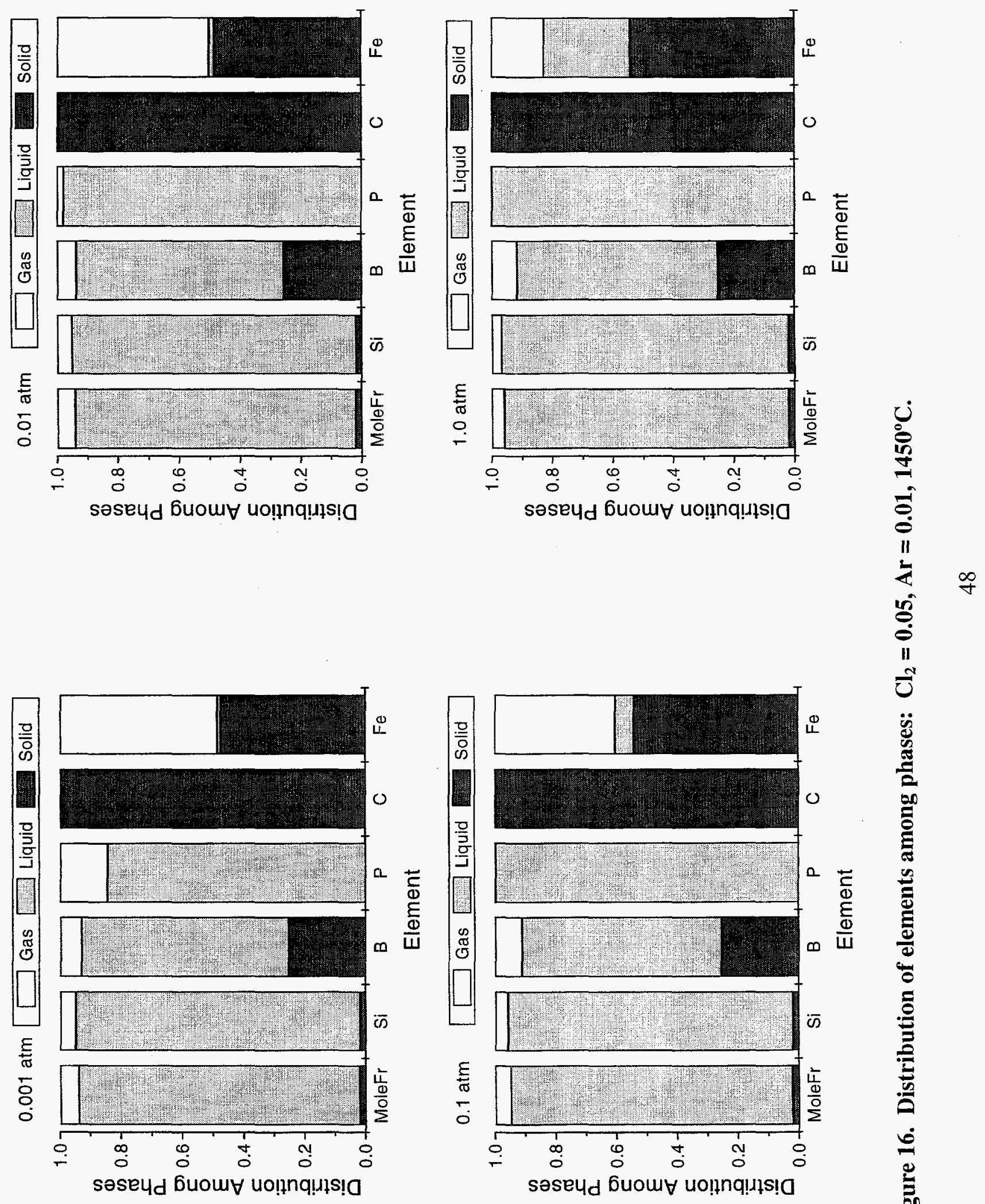

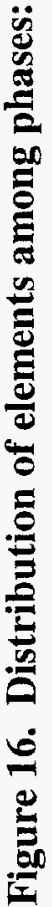



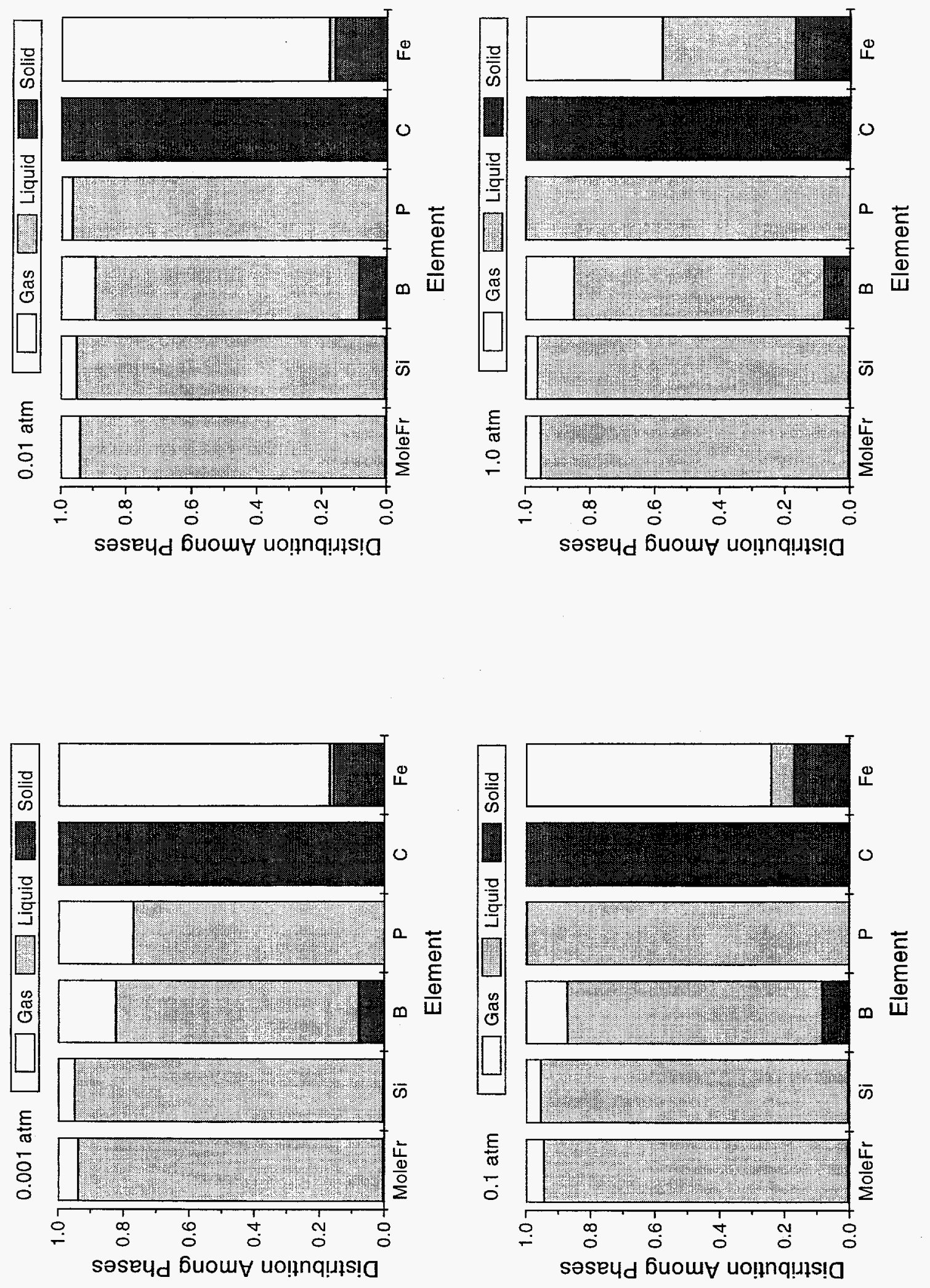

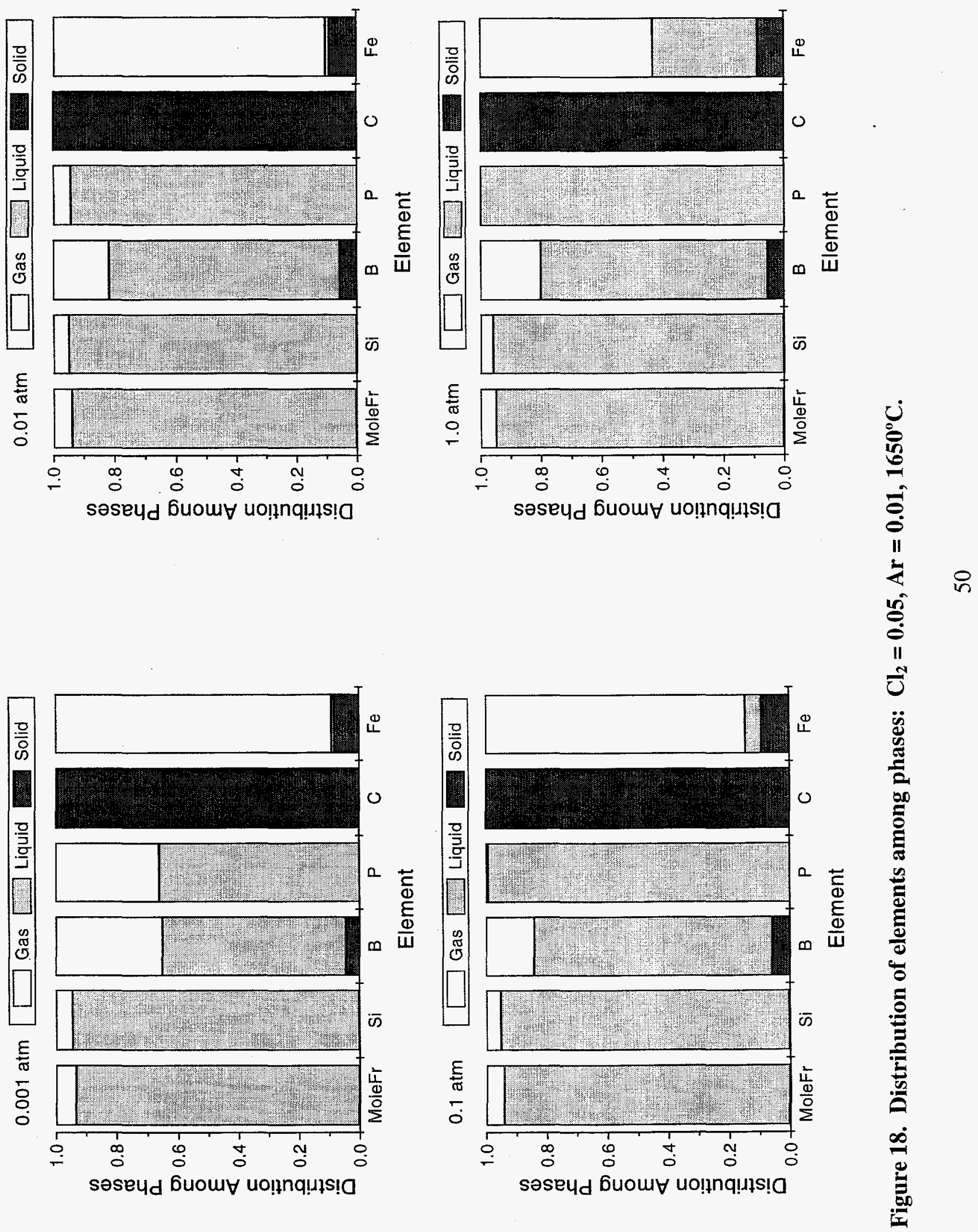
Table 9. Dominant* chemical species for silicon and impurities with $\mathrm{Cl}_{2} / \mathrm{Ar}$ addition.

\begin{tabular}{|c|c|c|c|c|c|c|c|}
\hline $\begin{array}{l}\text { Temp. } \\
\left({ }^{\circ} \mathrm{C}\right)\end{array}$ & $\begin{array}{l}\text { Pressure } \\
(\mathrm{atm})\end{array}$ & Phase & $\mathrm{Si}$ & B & $\mathrm{P}$ & C & $\mathrm{Fe}$ \\
\hline 1450 & 0.001 & $\begin{array}{l}\text { Gas } \\
\text { Liquid } \\
\text { Solid } \\
\end{array}$ & $\begin{array}{l}\mathrm{SiCl}_{2} \\
\mathrm{Si}(\mathrm{L}) \\
\mathrm{Si}(\mathrm{S})\end{array}$ & $\begin{array}{l}\mathrm{BCl} \\
\mathrm{B}(\mathrm{L}) \\
\mathrm{B}(\mathrm{S}) \\
\end{array}$ & $\begin{array}{l}\mathrm{P}_{2} \\
\mathrm{P}(\mathrm{L}) \\
\mathrm{P}(\mathrm{cr})\end{array}$ & $\begin{array}{l}\mathrm{Si}_{2} \mathrm{C} \\
- \\
\mathrm{SiC}(\mathrm{B}) \\
\end{array}$ & $\begin{array}{l}\mathrm{FeCl} \\
\mathrm{Fe}(\mathrm{L}) \\
\mathrm{Fe}(\alpha, \delta, \gamma) \\
\end{array}$ \\
\hline 1450 & 0.01 & $\begin{array}{l}\text { Gas } \\
\text { Liquid } \\
\text { Solid } \\
\end{array}$ & $\begin{array}{l}\mathrm{SiCl}_{2} \\
\mathrm{Si}(\mathrm{L}) \\
\mathrm{Si}(\mathrm{S})\end{array}$ & $\begin{array}{l}\mathrm{BCl}_{3}, \mathrm{BCl} \\
\mathrm{B}(\mathrm{L}) \\
\mathrm{B}(\mathrm{S}) \\
\end{array}$ & \begin{tabular}{|l|}
$\mathrm{P}_{2}$ \\
$\mathrm{P}(\mathrm{L})$ \\
$\mathrm{P}(\mathrm{cr})$ \\
\end{tabular} & $\begin{array}{l}\mathrm{Si}_{2} \mathrm{C} \\
-- \\
\mathrm{SiC}(\mathrm{B}) \\
\end{array}$ & $\begin{array}{l}\mathrm{FeCl} l_{2} \\
\mathrm{Fe}(\mathrm{L}), \mathrm{FeCl}_{2}(\mathrm{~L}) \\
\mathrm{Fe}(\alpha, \delta, \gamma)\end{array}$ \\
\hline 1450 & 0.1 & $\begin{array}{l}\text { Gas } \\
\text { Liquid } \\
\text { Solid }\end{array}$ & $\begin{array}{l}\mathrm{SiCl}_{2} \\
\mathrm{Si}(\mathrm{L}) \\
\mathrm{Si}(\mathrm{S}) \\
\end{array}$ & $\begin{array}{l}\mathrm{BCl}_{3} \\
\mathrm{~B}(\mathrm{~L}) \\
\mathrm{B}(\mathrm{S}) \\
\end{array}$ & $\begin{array}{l}\mathrm{P}_{2} \\
\mathrm{P}(\mathrm{L}) \\
\mathrm{P}(\mathrm{cr})\end{array}$ & $\begin{array}{l}\mathrm{Si}_{2} \mathrm{C} \\
- \\
\mathrm{SiC}(\mathrm{B})\end{array}$ & $\begin{array}{l}\mathrm{FeCl}_{2} \\
\mathrm{FeCl}(\mathrm{L}) \\
\mathrm{Fe}(\alpha, \delta, \gamma)\end{array}$ \\
\hline 1450 & 1.0 & $\begin{array}{l}\text { Gas } \\
\text { Liquid } \\
\text { Solid }\end{array}$ & $\begin{array}{l}\mathrm{SiCl}_{4}, \mathrm{SiCl}_{2} \\
\mathrm{Si}(\mathrm{L}) \\
\mathrm{Si}(\mathrm{S})\end{array}$ & $\begin{array}{l}\mathrm{BCl}_{3} \\
\mathrm{~B}(\mathrm{~L}) \\
\mathrm{B}(\mathrm{S})\end{array}$ & $\begin{array}{l}\mathrm{P}_{2} \\
\mathrm{P}(\mathrm{L}) \\
\mathrm{P}(\mathrm{cr})\end{array}$ & $\begin{array}{l}\mathrm{Si}_{2} \mathrm{C} \\
- \\
\mathrm{SiC}(\mathrm{B})\end{array}$ & $\begin{array}{l}\mathrm{FeCl}_{2} \\
\mathrm{FeCl}_{2}(\mathrm{~L}) \\
\mathrm{Fe}(\alpha, \delta, \gamma)\end{array}$ \\
\hline 1550 & 0.001 & $\begin{array}{l}\text { Gas } \\
\text { Liquid } \\
\text { Solid }\end{array}$ & \begin{tabular}{|l|}
$\mathrm{SiCl}{ }_{2}$ \\
$\mathrm{Si}(\mathrm{L})$ \\
$\mathrm{Si}(\mathrm{S})$ \\
\end{tabular} & $\begin{array}{l}\mathrm{BCl} \\
\mathrm{B}(\mathrm{L}) \\
\mathrm{B}(\mathrm{S})\end{array}$ & $\begin{array}{l}\mathrm{P}_{2} \\
\mathrm{P}(\mathrm{L}) \\
\mathrm{P}(\mathrm{cr})\end{array}$ & $\begin{array}{l}\mathrm{Si}_{2} \mathrm{C} \\
- \\
\mathrm{SiC}(\mathrm{B})\end{array}$ & $\begin{array}{l}\mathrm{FeCl} l_{2} \\
\mathrm{Fe}(\mathrm{L}) \\
\mathrm{Fe}(\alpha, \delta, \gamma)\end{array}$ \\
\hline 1550 & 0.01 & $\begin{array}{l}\text { Gas } \\
\text { Liquid } \\
\text { Solid }\end{array}$ & $\begin{array}{l}\mathrm{SiCl}_{2} \\
\mathrm{Si}(\mathrm{L}) \\
\mathrm{Si}(\mathrm{S})\end{array}$ & $\begin{array}{l}\mathrm{BCl}, \mathrm{BCl}_{3} \\
\mathrm{~B}(\mathrm{~L}) \\
\mathrm{B}(\mathrm{S})\end{array}$ & $\begin{array}{l}\mathrm{P}_{2} \\
\mathrm{P}(\mathrm{L}) \\
\mathrm{P}(\mathrm{cr})\end{array}$ & $\begin{array}{l}\mathrm{Si}_{2} \mathrm{C} \\
- \\
\mathrm{SiC}(\mathrm{B})\end{array}$ & $\begin{array}{l}\mathrm{FeCl}_{2} \\
\mathrm{Fe}(\mathrm{L}), \mathrm{FeCl}_{2}(\mathrm{~L}) \\
\mathrm{Fe}(\alpha, \delta, \gamma)\end{array}$ \\
\hline 1550 & $\begin{array}{l}0.1- \\
1.0\end{array}$ & $\begin{array}{l}\text { Gas } \\
\text { Liquid } \\
\text { Solid } \\
\end{array}$ & $\begin{array}{l}\mathrm{SiCl}_{2} \\
\mathrm{Si}(\mathrm{L}) \\
\mathrm{Si}(\mathrm{S})\end{array}$ & $\begin{array}{l}\mathrm{BCl}_{3} \\
\mathrm{~B}(\mathrm{~L}) \\
\mathrm{B}(\mathrm{S}) \\
\end{array}$ & $\begin{array}{l}\mathrm{P}_{2} \\
\mathrm{P}(\mathrm{L}) \\
\mathrm{P}(\mathrm{cr}) \\
\end{array}$ & $\begin{array}{l}\mathrm{Si}_{2} \mathrm{C} \\
- \\
\mathrm{SiC}(\mathrm{B})\end{array}$ & $\begin{array}{l}\mathrm{FeCl}_{2} \\
\mathrm{FeCl}(\mathrm{L}) \\
\mathrm{Fe}(\alpha, \delta, \gamma)\end{array}$ \\
\hline 1650 & 0.001 & $\begin{array}{l}\text { Gas } \\
\text { Liquid } \\
\text { Solid }\end{array}$ & $\begin{array}{l}\mathrm{SiCl}_{2} \\
\mathrm{Si}(\mathrm{L}) \\
\mathrm{Si}(\mathrm{S})\end{array}$ & $\begin{array}{l}\mathrm{BCl} \\
\mathrm{B}(\mathrm{L}) \\
\mathrm{B}(\mathrm{S})\end{array}$ & $\begin{array}{l}\mathrm{P}_{2} \\
\mathrm{P}(\mathrm{L}) \\
\mathrm{P}(\mathrm{cr})\end{array}$ & $\begin{array}{l}\mathrm{Si}{ }_{2} \mathrm{C} \\
- \\
\mathrm{SiC}(\mathrm{B})\end{array}$ & $\begin{array}{l}\mathrm{FeCl} 2 \\
\mathrm{Fe}(\mathrm{L}) \\
\mathrm{Fe}(\alpha, \delta, \gamma)\end{array}$ \\
\hline 1650 & 0.01 & $\begin{array}{l}\text { Gas } \\
\text { Liquid } \\
\text { Solid } \\
\end{array}$ & $\begin{array}{l}\mathrm{SiCl}_{2} \\
\mathrm{Si}(\mathrm{L}) \\
\mathrm{Si}(\mathrm{S})\end{array}$ & $\begin{array}{l}\mathrm{BCl} \\
\mathrm{B}(\mathrm{L}) \\
\mathrm{B}(\mathrm{S}) \\
\end{array}$ & $\begin{array}{l}\mathrm{P}_{2} \\
\mathrm{P}(\mathrm{L}) \\
\mathrm{P}(\mathrm{cr})\end{array}$ & $\begin{array}{l}\mathrm{Si}_{2} \mathrm{C} \\
- \\
\mathrm{SiC}(\mathrm{B}) \\
\end{array}$ & $\begin{array}{l}\mathrm{FeCl} l_{2} \\
\mathrm{Fe}(\mathrm{L}), \mathrm{FeCl}_{2}(\mathrm{~L}) \\
\mathrm{Fe}(\alpha, \delta, \gamma)\end{array}$ \\
\hline 1650 & 0.1 & $\begin{array}{l}\text { Gas } \\
\text { Liquid } \\
\text { Solid } \\
\end{array}$ & $\begin{array}{l}\mathrm{SiCl}_{2} \\
\mathrm{Si}(\mathrm{L}) \\
\mathrm{Si}(\mathrm{S}) \\
\end{array}$ & $\begin{array}{l}\mathrm{BCl}_{3}, \mathrm{BCl} \\
\mathrm{B}(\mathrm{L}) \\
\mathrm{B}(\mathrm{S})\end{array}$ & $\begin{array}{l}\mathrm{P}_{2}, \mathrm{P} \\
\mathrm{P}(\mathrm{L}) \\
\mathrm{P}(\mathrm{cr})\end{array}$ & $\begin{array}{l}\mathrm{Si}_{2} \mathrm{C} \\
- \\
\mathrm{SiC}(\mathrm{B})\end{array}$ & $\begin{array}{l}\mathrm{FeCl}_{2} \\
\mathrm{FeCl}(\mathrm{L}) \\
\mathrm{Fe}(\alpha, \delta, \gamma)\end{array}$ \\
\hline 1650 & 1.0 & $\begin{array}{l}\text { Gas } \\
\text { Liquid } \\
\text { Solid } \\
\end{array}$ & $\begin{array}{l}\mathrm{SiCl}_{2}, \mathrm{SiCl}_{4} \\
\mathrm{Si}(\mathrm{L}) \\
\mathrm{Si}(\mathrm{S})\end{array}$ & $\begin{array}{l}\mathrm{BCl}_{3} \\
\mathrm{~B}(\mathrm{~L}) \\
\mathrm{B}(\mathrm{S})\end{array}$ & $\begin{array}{l}\mathrm{P}_{2}, \mathrm{PCl}, \mathrm{P} \\
\mathrm{P}(\mathrm{L}) \\
\mathrm{P}(\mathrm{cr})\end{array}$ & $\begin{array}{l}\mathrm{Si}{ }_{2} \mathrm{C} \\
- \\
\mathrm{SiC}(\mathrm{B})\end{array}$ & $\begin{array}{l}\mathrm{FeCl}_{2} \\
\mathrm{FeCl}_{2}(\mathrm{~L}) \\
\mathrm{Fe}(\alpha, \delta, \gamma)\end{array}$ \\
\hline
\end{tabular}

* Chemical species are listed for each phase in order of decreasing mole fraction as a function of temperature and pressure. If multiple species are listed, each represents at least $\sim 20 \%$ of the element in that phase. 


\section{G. $\mathrm{Cl}_{2} / \mathrm{O}_{2}$ Addition}

Figure 19 through Figure 21 and Table 10 give results for $\mathrm{Cl}_{2}$ plus $\mathrm{O}_{2}$ addition. As expected, they show a combination of the features seen in sections III.A. and III.F. Especially at the lower pressures and higher temperatures, iron is vaporized as $\mathrm{FeCl}_{2}$ by reaction with the $\mathrm{Cl}_{2}$, and carbon is vaporized as $\mathrm{CO}$ by reaction with the $\mathrm{O}_{2}$. The phosphorus that does vaporize is primarily $\mathrm{P}_{2}$ or $\mathrm{P}$; only a small amounts reacts to form $\mathrm{PCl}$ at the higher pressures and temperature. A moderate amount of boron is vaporized as $\mathrm{BCl}_{\mathrm{x}}(\mathrm{x}=1,3)$, again at the higher pressures and temperatures. The gaseous silicon-containing compounds are primarily $\mathrm{SiO}$ at the lower pressures and the $\mathrm{SiCl}_{\mathrm{x}}(\mathrm{x}=2,4)$ compounds at higher pressures. In both cases, most of the chlorine and the oxygen input into the system reacts with silicon, but at the higher pressures, the oxide is liquid rather than gaseous. Overall, the thermochemistry of $\mathrm{Cl}_{2}$ and $\mathrm{O}_{2}$ addition appears offer good potential for removal of $\mathrm{Fe}$ and $\mathrm{C}$ from $\mathrm{Si}$, especially at the lower pressures and higher temperatures. The same conditions should remove some $\mathrm{B}$, as well as $\mathrm{P}$ by evaporation. 

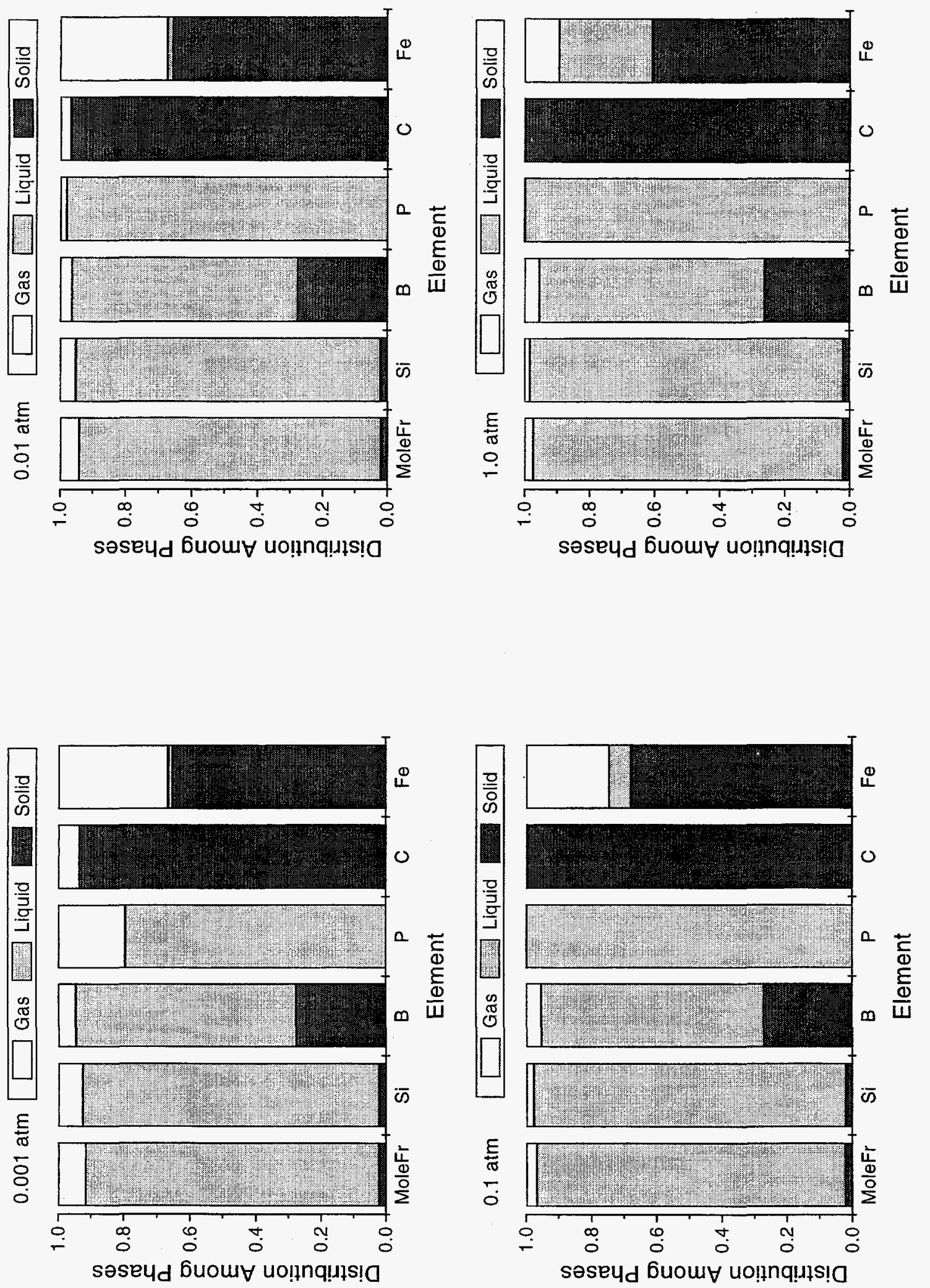

ن 

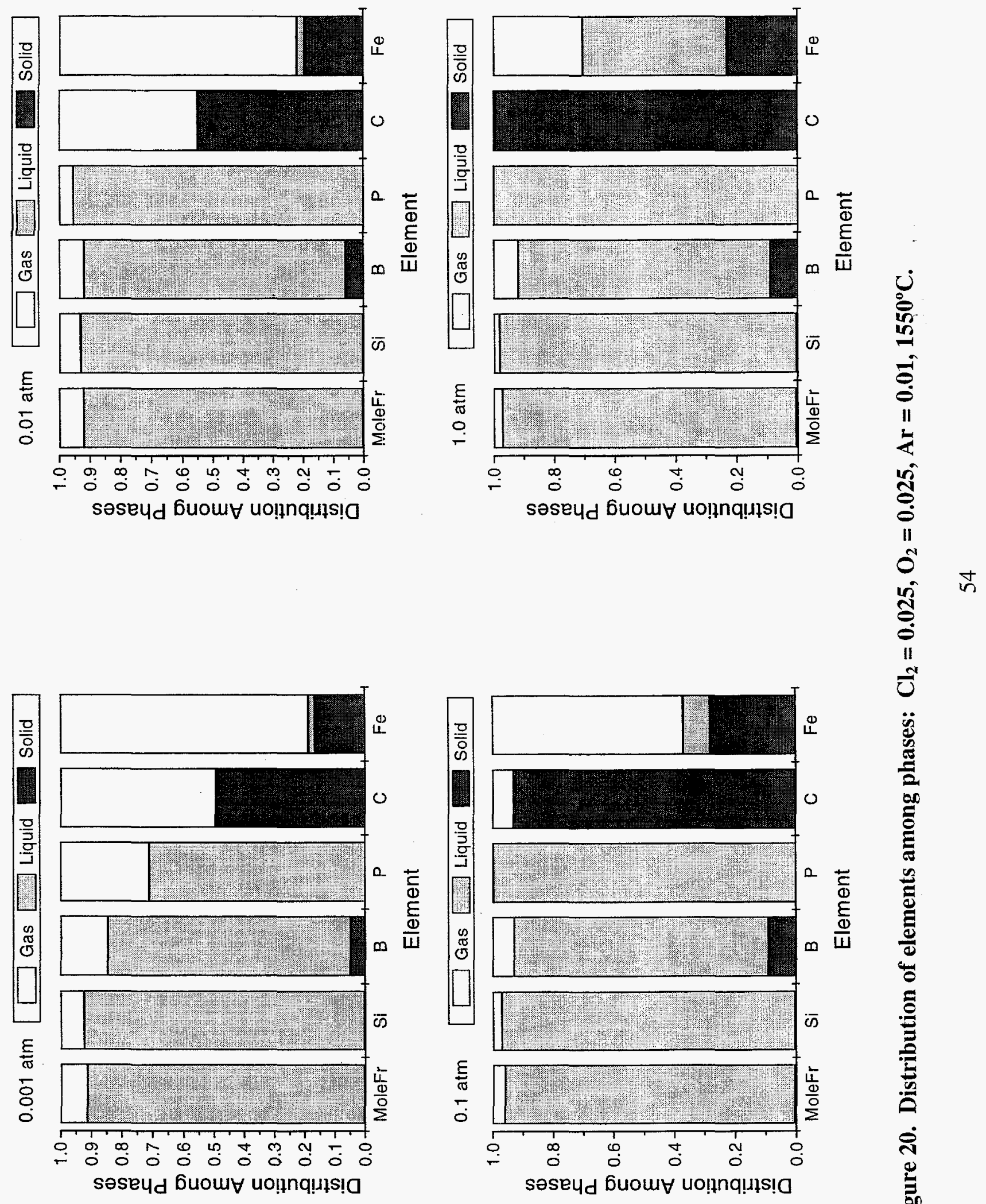

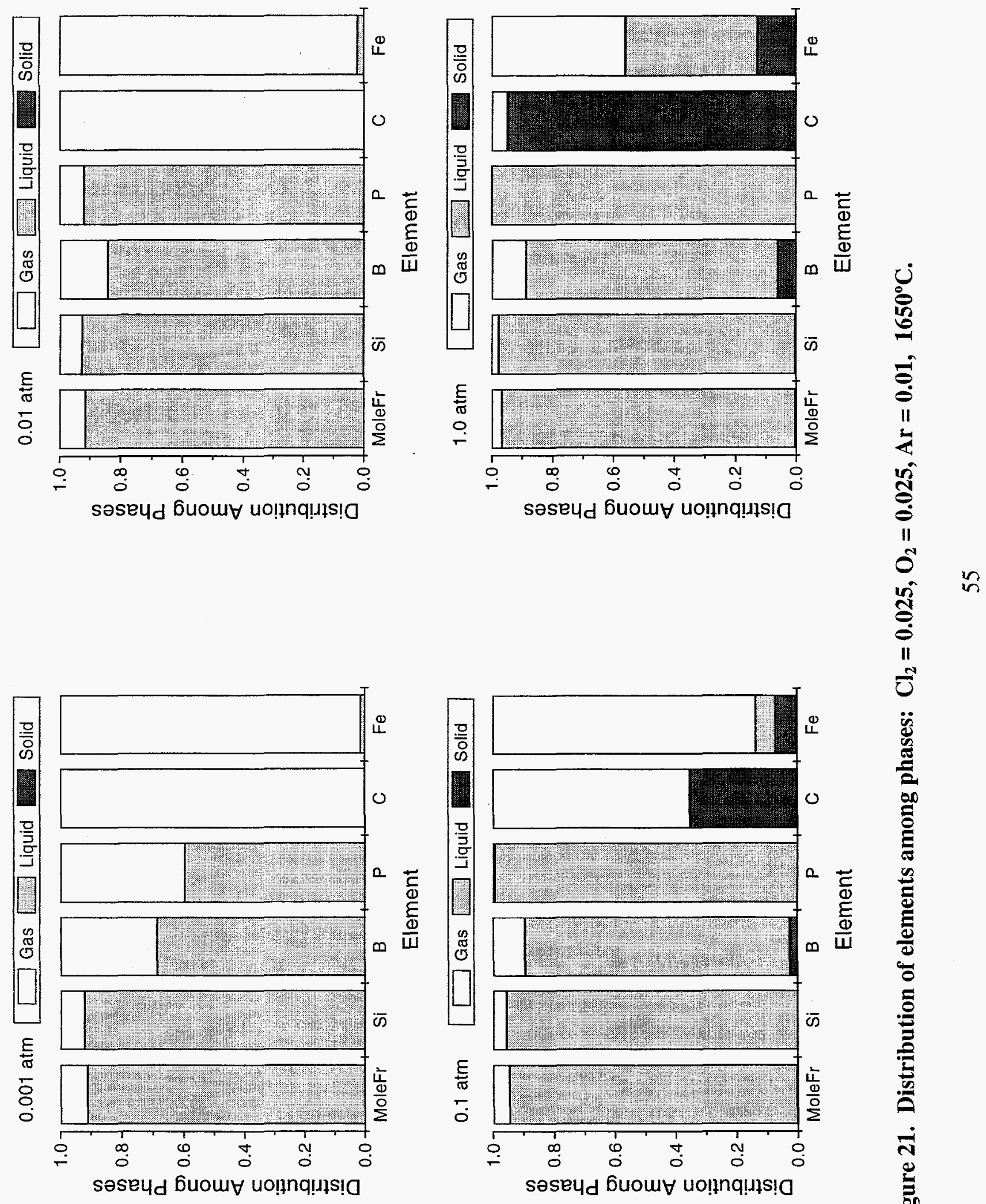

苞 
Table 10. Dominant* chemical species for silicon and impurities with $\mathrm{Cl}_{2} / \mathrm{O}_{2} / \mathrm{Ar}$ addition.

\begin{tabular}{|c|c|c|c|c|c|c|c|}
\hline $\begin{array}{l}\text { Temp. } \\
\left({ }^{\circ} \mathrm{C}\right)\end{array}$ & $\begin{array}{l}\text { Pressure } \\
\text { (atm) }\end{array}$ & Phase & $\mathrm{Si}$ & B & $\mathrm{P}$ & C & $\mathrm{Fe}$ \\
\hline 1450 & 0.001 & $\begin{array}{l}\text { Gas } \\
\text { Liquid } \\
\text { Solid } \\
\end{array}$ & $\begin{array}{l}\mathrm{SiO}, \mathrm{SiCl}_{2} \\
\mathrm{Si}(\mathrm{L}) \\
\mathrm{Si}(\mathrm{S}) \\
\end{array}$ & $\begin{array}{l}\mathrm{BCl} \\
\mathrm{B}(\mathrm{L}) \\
\mathrm{B}(\mathrm{S}) \\
\end{array}$ & $\begin{array}{l}\mathrm{P}_{2} \\
\mathrm{P}(\mathrm{L}) \\
\mathrm{P}(\mathrm{cr})\end{array}$ & \begin{tabular}{|l}
$\mathrm{CO}$ \\
- \\
$\mathrm{SiC}(\mathrm{B})$ \\
\end{tabular} & $\begin{array}{l}\mathrm{FeCl} \\
\mathrm{Fe}(\mathrm{L}) \\
\mathrm{Fe}(\alpha, \delta, \gamma)\end{array}$ \\
\hline 1450 & 0.01 & \begin{tabular}{|l|} 
Gas \\
Liquid \\
Solid \\
\end{tabular} & \begin{tabular}{|l}
$\mathrm{SiO}, \mathrm{SiCl}_{2}$ \\
$\mathrm{Si}(\mathrm{L})$ \\
$\mathrm{Si}(\mathrm{S})$ \\
\end{tabular} & $\begin{array}{l}\mathrm{BCl}_{3}, \mathrm{BCl} \\
\mathrm{B}(\mathrm{L}) \\
\mathrm{B}(\mathrm{S}) \\
\end{array}$ & \begin{tabular}{|l|}
$\mathrm{P}_{2}$ \\
$\mathrm{P}(\mathrm{L})$ \\
$\mathrm{P}(\mathrm{cr})$ \\
\end{tabular} & \begin{tabular}{|l}
$\mathrm{CO}$ \\
- \\
$\mathrm{SiC}(\mathrm{B})$ \\
\end{tabular} & $\begin{array}{l}\mathrm{FeCl}_{2} \\
\mathrm{Fe}(\mathrm{L}), \mathrm{FeCl}_{2}(\mathrm{~L}) \\
\mathrm{Fe}(\alpha, \delta, \gamma)\end{array}$ \\
\hline 1450 & 0.1 & $\begin{array}{l}\text { Gas } \\
\text { Liquid } \\
\text { Solid } \\
\end{array}$ & $\begin{array}{l}\mathrm{SiCl}_{2} \\
\mathrm{Si}(\mathrm{L}) \\
\mathrm{Si}(\mathrm{S}) \\
\end{array}$ & \begin{tabular}{|l}
$\mathrm{BCl}$ \\
$\mathrm{B}(\mathrm{L})$ \\
$\mathrm{B}(\mathrm{S})$ \\
\end{tabular} & \begin{tabular}{|l}
$\mathrm{P}_{2}$ \\
$\mathrm{P}(\mathrm{L})$ \\
$\mathrm{P}(\mathrm{cr})$
\end{tabular} & $\begin{array}{l}\mathrm{CO} \\
- \\
\mathrm{SiC}(\mathrm{B})\end{array}$ & $\begin{array}{l}\mathrm{FeCl}_{2} \\
\mathrm{FeCl}_{2}(\mathrm{~L}), \mathrm{Fe}(\mathrm{L}) \\
\mathrm{Fe}(\alpha, \delta, \gamma)\end{array}$ \\
\hline 1450 & 1.0 & \begin{tabular}{|l|} 
Gas \\
Liquid \\
Solid \\
\end{tabular} & $\begin{array}{l}\mathrm{SiCl}, \mathrm{SiCl}_{4} \\
\mathrm{Si}(\mathrm{L}) \\
\mathrm{Si}(\mathrm{S}) \\
\end{array}$ & $\begin{array}{l}\mathrm{BCl} \\
\mathrm{B}(\mathrm{L}) \\
\mathrm{B}(\mathrm{S}) \\
\end{array}$ & $\begin{array}{l}\mathrm{P}_{2} \\
\mathrm{P}(\mathrm{L}) \\
\mathrm{P}(\mathrm{cr})\end{array}$ & \begin{tabular}{|l|}
$\mathrm{CO}$ \\
- \\
$\mathrm{SiC}(\mathrm{B})$ \\
\end{tabular} & $\begin{array}{l}\mathrm{FeCl}_{2} \\
\mathrm{FeCl}(\mathrm{L}) \\
\mathrm{Fe}(\alpha, \delta, \gamma) \\
\end{array}$ \\
\hline 1550 & 0.001 & $\begin{array}{l}\text { Gas } \\
\text { Liquid } \\
\text { Solid }\end{array}$ & $\begin{array}{l}\mathrm{SiO}, \mathrm{SiCl}_{2} \\
\mathrm{Si}(\mathrm{L}) \\
\mathrm{Si}(\mathrm{S})\end{array}$ & $\begin{array}{l}\mathrm{BCl} \\
\mathrm{B}(\mathrm{L}) \\
\mathrm{B}(\mathrm{S})\end{array}$ & $\begin{array}{l}\mathrm{P}_{2}, \mathrm{P} \\
\mathrm{P}(\mathrm{L}) \\
\mathrm{P}(\mathrm{cr})\end{array}$ & $\begin{array}{l}\mathrm{CO} \\
-- \\
\mathrm{SiC}(\mathrm{B})\end{array}$ & \begin{tabular}{|l}
$\mathrm{FeCl}$ \\
$\mathrm{Fe}(\mathrm{L})$ \\
$\mathrm{Fe}(\alpha, \delta, \gamma)$
\end{tabular} \\
\hline 1550 & 0.01 & \begin{tabular}{|l|} 
Gas \\
Liquid \\
Solid \\
\end{tabular} & $\begin{array}{l}\mathrm{SiO}, \mathrm{SiCl}_{2} \\
\mathrm{Si}(\mathrm{L}) \\
\mathrm{Si}(\mathrm{S})\end{array}$ & $\begin{array}{l}\mathrm{BCl} \\
\mathrm{B}(\mathrm{L}) \\
\mathrm{B}(\mathrm{S})\end{array}$ & $\begin{array}{l}\mathrm{P}_{2} \\
\mathrm{P}(\mathrm{L}) \\
\mathrm{P}(\mathrm{cr})\end{array}$ & $\begin{array}{l}\mathrm{CO} \\
- \\
\mathrm{SiC}(\mathrm{B}) \\
\end{array}$ & \begin{tabular}{|l|}
$\mathrm{FeCl} l_{2}$ \\
$\mathrm{Fe}(\mathrm{L})$ \\
$\mathrm{Fe}(\alpha, \delta, \gamma)$ \\
\end{tabular} \\
\hline 1550 & 0.1 & \begin{tabular}{|l|} 
Gas \\
Liquid \\
Solid \\
\end{tabular} & $\begin{array}{l}\mathrm{SiCl}_{2}, \mathrm{SiO} \\
\mathrm{Si}(\mathrm{L}) \\
\mathrm{Si}(\mathrm{S})\end{array}$ & $\begin{array}{l}\mathrm{BCl} \\
\mathrm{B}(\mathrm{L}) \\
\mathrm{B}(\mathrm{S}) \\
\end{array}$ & \begin{tabular}{|l|}
$\mathrm{P}_{2}$ \\
$\mathrm{P}(\mathrm{L})$ \\
$\mathrm{P}(\mathrm{cr})$ \\
\end{tabular} & \begin{tabular}{|l}
$\mathrm{CO}$ \\
- \\
$\mathrm{SiC}(\mathrm{B})$ \\
\end{tabular} & $\begin{array}{l}\mathrm{FeCl}_{2} \\
\mathrm{FeCl}_{2}(\mathrm{~L}), \mathrm{Fe}(\mathrm{L}) \\
\mathrm{Fe}(\alpha, \delta, \gamma)\end{array}$ \\
\hline 1550 & 1.0 & \begin{tabular}{|l|} 
Gas \\
Liquid \\
Solid \\
\end{tabular} & $\begin{array}{l}\mathrm{SiCl}_{2}, \mathrm{SiCl}_{4} \\
\mathrm{Si}(\mathrm{L}) \\
\mathrm{Si}(\mathrm{S}), \mathrm{SiC}(\mathrm{B})\end{array}$ & $\begin{array}{l}\mathrm{BCl}_{3} \\
\mathrm{~B}(\mathrm{~L}) \\
\mathrm{B}(\mathrm{S}) \\
\end{array}$ & $\begin{array}{l}\mathrm{P}_{2} \\
\mathrm{P}(\mathrm{L}) \\
\mathrm{P}(\mathrm{cr})\end{array}$ & \begin{tabular}{|l|}
$\mathrm{CO}$ \\
-- \\
$\mathrm{SiC}(\mathrm{B})$ \\
\end{tabular} & \begin{tabular}{|l|}
$\mathrm{FeCl} l_{2}$ \\
$\mathrm{FeCl}(2)$ \\
$\mathrm{Fe}(\alpha, \delta, \gamma)$ \\
\end{tabular} \\
\hline 1650 & 0.001 & \begin{tabular}{|l|} 
Gas \\
Liquid \\
Solid \\
\end{tabular} & $\begin{array}{l}\mathrm{SiO}, \mathrm{SiCl}_{2} \\
\mathrm{Si}(\mathrm{L}) \\
-\end{array}$ & \begin{tabular}{|l|}
$\mathrm{BCl}$ \\
$\mathrm{B}(\mathrm{L})$ \\
-- \\
\end{tabular} & $\begin{array}{l}\mathrm{P}_{2}, \mathrm{P} \\
\mathrm{P}(\mathrm{L}) \\
--\end{array}$ & \begin{tabular}{|l|}
$\mathrm{CO}$ \\
-- \\
-- \\
\end{tabular} & \begin{tabular}{|l}
$\mathrm{FeCl}$, \\
$\mathrm{Fe}(\mathrm{L})$ \\
-- \\
\end{tabular} \\
\hline 1650 & 0.01 & \begin{tabular}{|l|} 
Gas \\
Liquid \\
Solid \\
\end{tabular} & $\begin{array}{l}\mathrm{SiO}, \mathrm{SiCl}_{2} \\
\mathrm{Si}(\mathrm{L}) \\
-\end{array}$ & \begin{tabular}{|l}
$\mathrm{BCl}$ \\
$\mathrm{B}(\mathrm{L})$ \\
-- \\
\end{tabular} & $\begin{array}{l}\mathrm{P}_{2}, \mathrm{P} \\
\mathrm{P}(\mathrm{L}) \\
-\end{array}$ & \begin{tabular}{|l|}
$\mathrm{CO}$ \\
-- \\
-- \\
\end{tabular} & \begin{tabular}{|l}
$\mathrm{FeCl}$ \\
$\mathrm{Fe}(\mathrm{L})$ \\
-- \\
\end{tabular} \\
\hline 1650 & 0.1 & \begin{tabular}{|l|} 
Gas \\
Liquid \\
Solid \\
\end{tabular} & $\begin{array}{l}\mathrm{SiCl}_{2}, \mathrm{SiO} \\
\mathrm{Si}(\mathrm{L}) \\
\mathrm{Si}(\mathrm{S}), \mathrm{SiC}(\mathrm{B})\end{array}$ & $\begin{array}{l}\mathrm{BCl}_{3}, \mathrm{BCl} \\
\mathrm{B}(\mathrm{L}) \\
\mathrm{B}(\mathrm{S})\end{array}$ & $\begin{array}{l}\mathrm{P}_{2}, \mathrm{P} \\
\mathrm{P}(\mathrm{L}) \\
\mathrm{P}(\mathrm{cr})\end{array}$ & \begin{tabular}{|l|}
$\mathrm{CO}$ \\
- \\
$\mathrm{SiC}(\mathrm{B})$ \\
\end{tabular} & $\begin{array}{l}\mathrm{FeCl}_{2} \\
\mathrm{FeCl}(\mathrm{L}), \mathrm{Fe}(\mathrm{L}) \\
\mathrm{Fe}(\alpha, \delta, \gamma)\end{array}$ \\
\hline 1650 & 1.0 & \begin{tabular}{|l|} 
Gas \\
Liquid \\
Solid \\
\end{tabular} & $\begin{array}{l}\mathrm{SiCl}_{2}, \mathrm{SiCl}_{4} \\
\mathrm{Si}(\mathrm{L}) \\
\mathrm{Si}(\mathrm{S}), \mathrm{SiC}(\mathrm{B})\end{array}$ & $\begin{array}{l}\mathrm{BCl} \\
\mathrm{B}(\mathrm{L}) \\
\mathrm{B}(\mathrm{S}) \\
\end{array}$ & $\begin{array}{l}\mathrm{P}_{2}, \mathrm{PCl}, \mathrm{P} \\
\mathrm{P}(\mathrm{L}) \\
\mathrm{P}(\mathrm{cr}) \\
\end{array}$ & \begin{tabular}{|l|}
$\mathrm{CO}$ \\
- \\
$\mathrm{SiC}(\mathrm{B})$ \\
\end{tabular} & $\begin{array}{l}\mathrm{FeCl} l_{2} \\
\mathrm{FeCl}_{2}(\mathrm{~L}) \\
\mathrm{Fe}(\alpha, \delta, \gamma) \\
\end{array}$ \\
\hline
\end{tabular}

* Chemical species are listed for each phase in order of decreasing mole fraction as a function of temperature and pressure. If multiple species are listed, each represents at least $\sim 20 \%$ of the element in that phase. 


\section{H. $\mathrm{SiCl}_{4}$ Addition}

Figure 22 through Figure 24 and Table 11 gives results for the addition of $\mathrm{SiCl}_{4}$ to the silicon and impurity elements. As expected, they closely resemble the results for $\mathrm{Cl}_{2}$ addition, with the variations expected given that, on a "per sccm" basis, $\mathrm{SiCl}_{4}$ provides twice as many chlorine atoms. Compared with the results for $\mathrm{Cl}_{2}$ and $\mathrm{HCl}, \mathrm{SiCl}_{4}$ addition leads to more vaporization of Fe and $\mathrm{B}$ for a given pressure and temperature. The distribution of silicon among the phases is quite similar for $\mathrm{Cl}_{2}$ and $\mathrm{SiCl}_{4}$ addition, as are the identity of the dominant chemical species. So, although there should be kinetic, safety, or operational differences (e.g. from the fact that $\mathrm{SiCl}_{4}$ is a liquid), from a chemical equilibrium point of view, $\mathrm{SiCl}_{4}$ and $\mathrm{Cl}_{2}$ addition are effectively the same. 

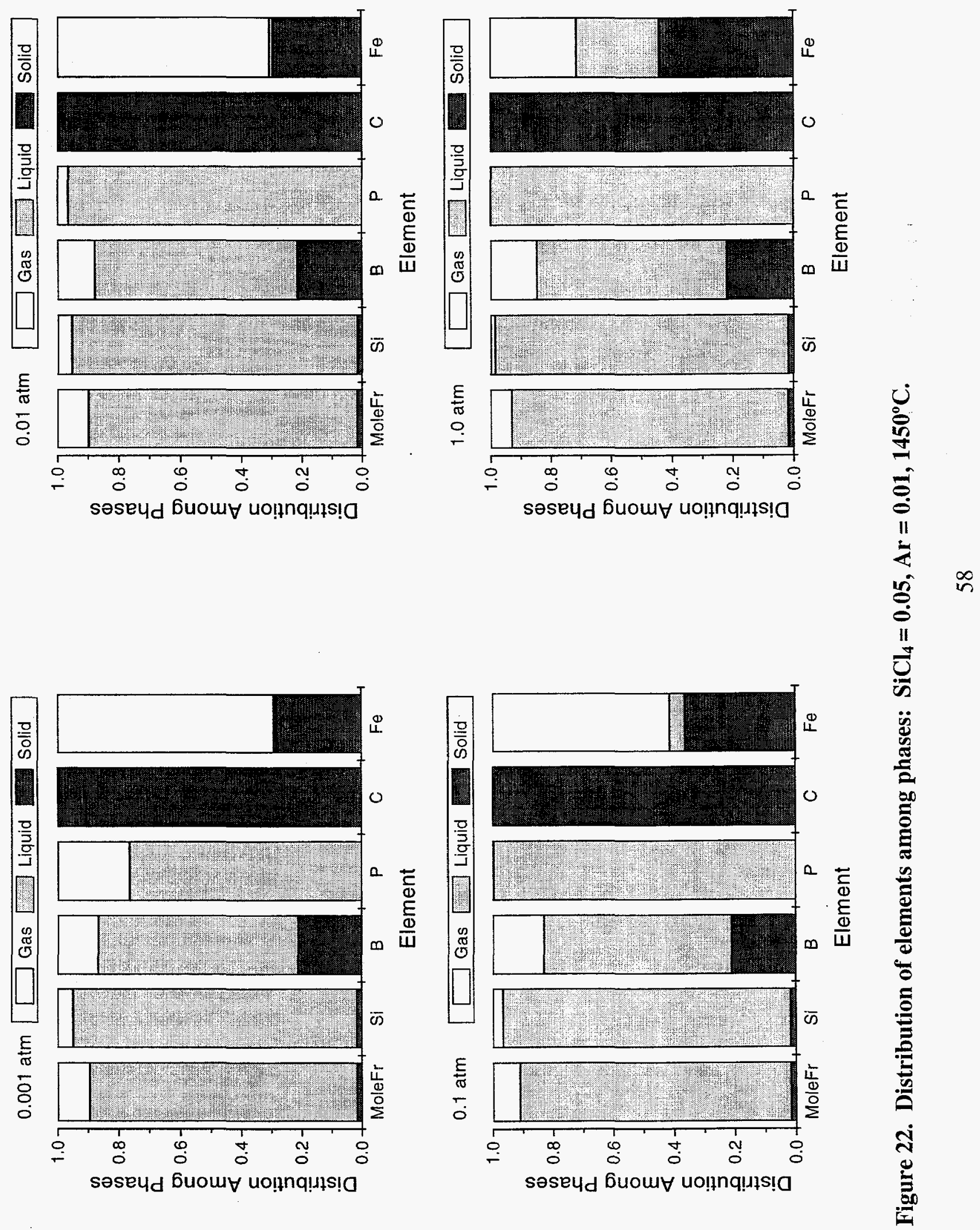

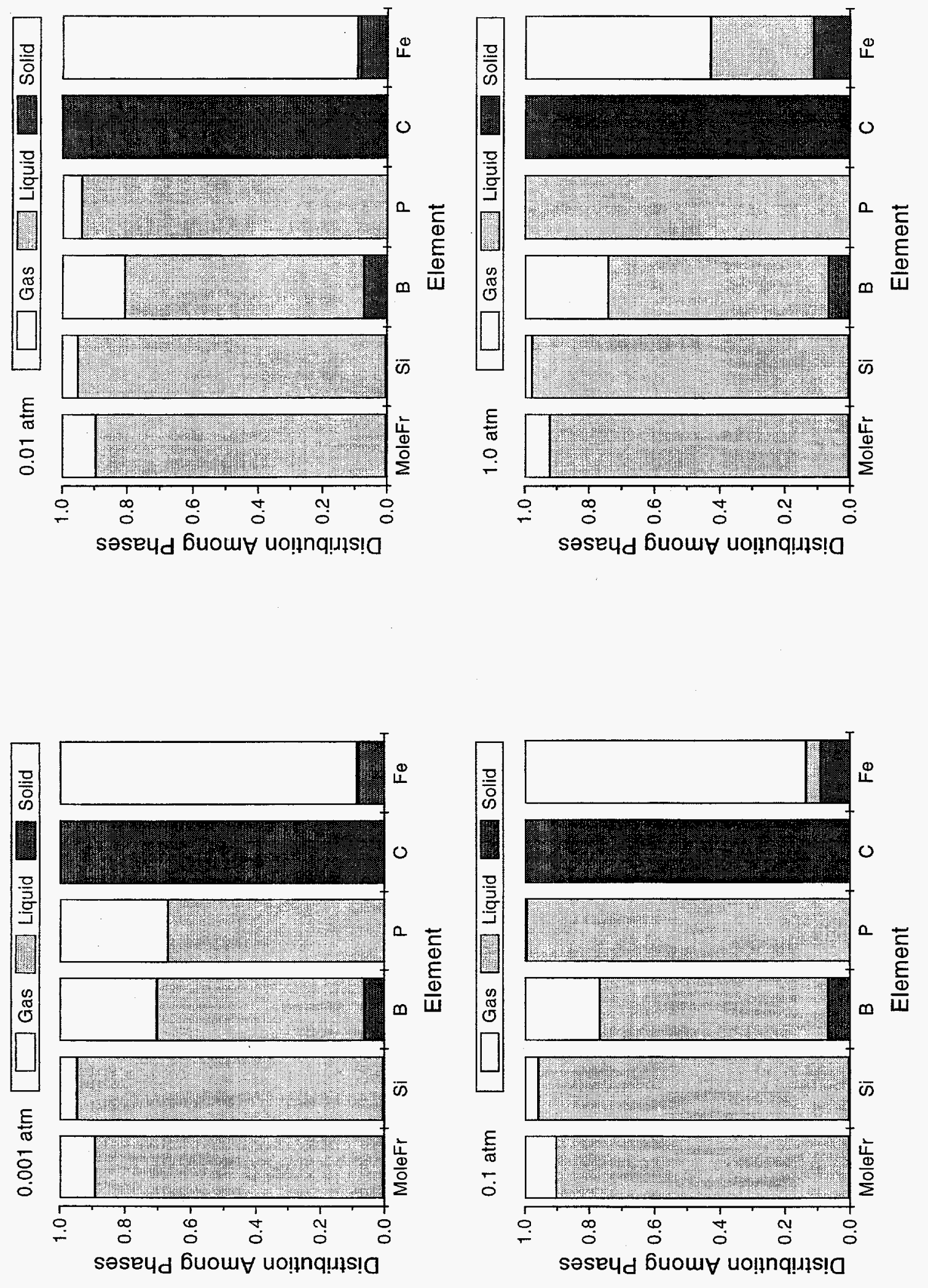

ن 

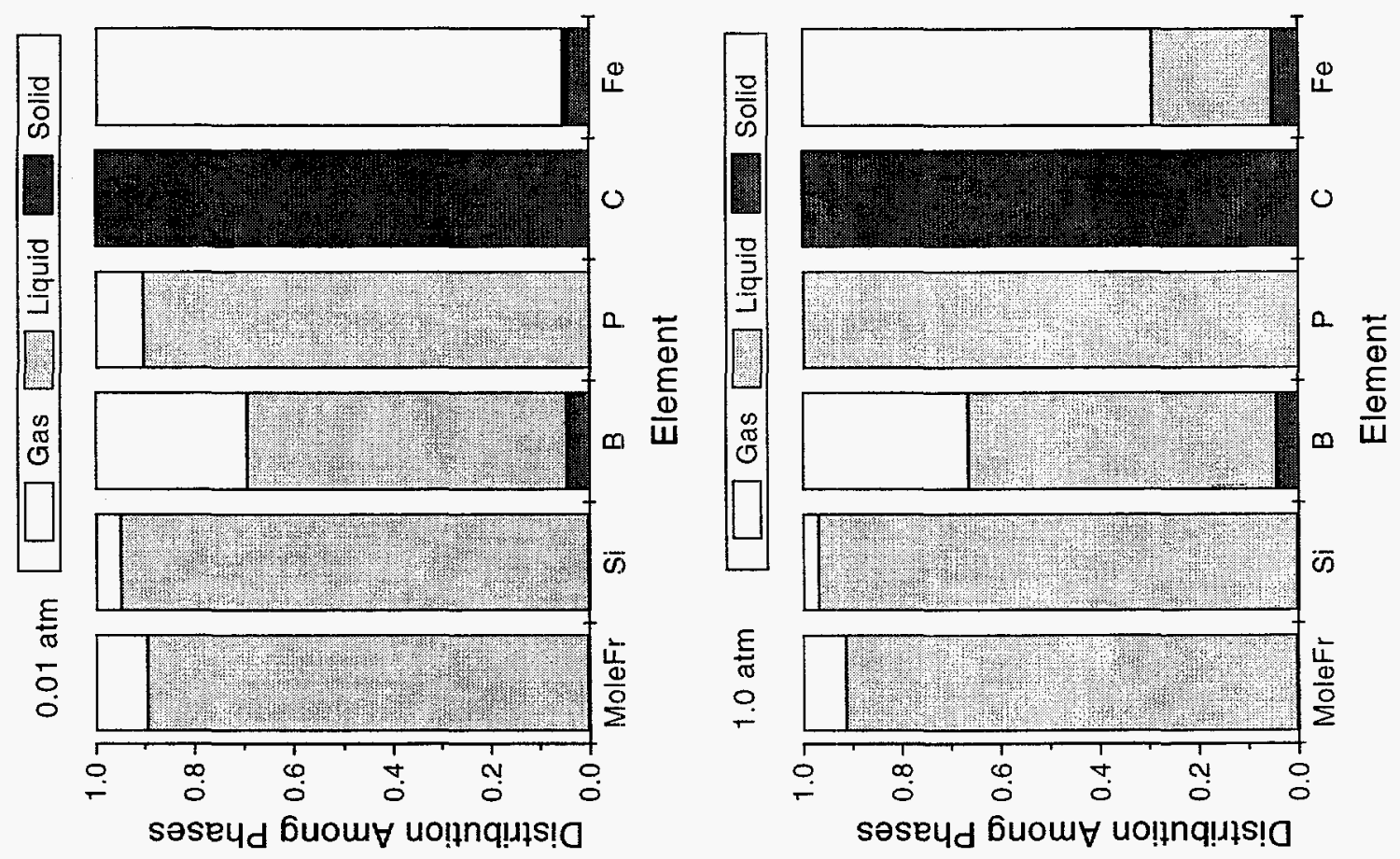

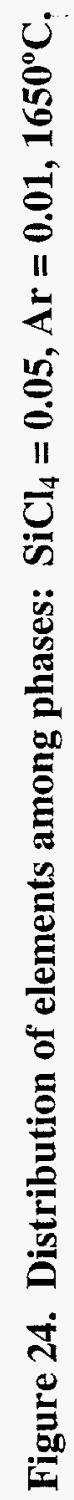
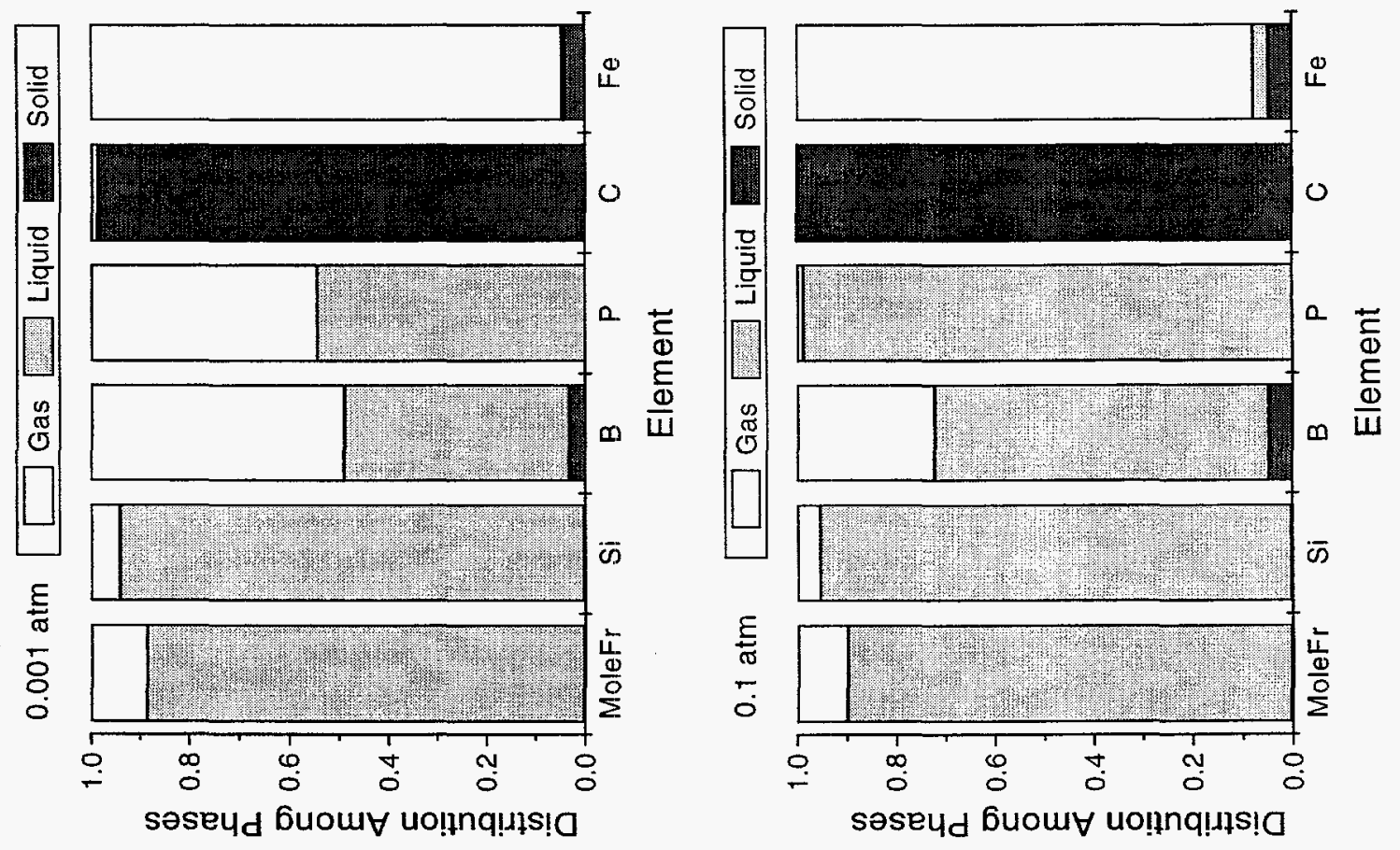
Table 11. Dominant* chemical species for silicon and impurities with $\mathrm{SiCl}_{4} / \mathrm{Ar}$ addition.

\begin{tabular}{|c|c|c|c|c|c|c|c|}
\hline $\begin{array}{l}\text { Temp. } \\
\left({ }^{\circ} \mathrm{C}\right)\end{array}$ & $\begin{array}{l}\text { Pressure } \\
\text { (atm) }\end{array}$ & Phase & $\mathrm{Si}$ & B & $\mathrm{P}$ & C & $\mathrm{Fe}$ \\
\hline 1450 & 0.001 & $\begin{array}{l}\text { Gas } \\
\text { Liquid } \\
\text { Solid } \\
\end{array}$ & $\begin{array}{l}\mathrm{SiCl}_{2} \\
\mathrm{Si}(\mathrm{L}) \\
\mathrm{Si}(\mathrm{S})\end{array}$ & $\begin{array}{l}\mathrm{BCl}, \mathrm{BCl}_{3} \\
\mathrm{~B}(\mathrm{~L}) \\
\mathrm{B}(\mathrm{S})\end{array}$ & $\begin{array}{l}\mathrm{P}_{2} \\
\mathrm{P}(\mathrm{L}) \\
\mathrm{P}(\mathrm{cr})\end{array}$ & $\begin{array}{l}\mathrm{Si}_{2} \mathrm{C} \\
- \\
\mathrm{SiC}(\mathrm{B}) \\
\end{array}$ & $\begin{array}{l}\mathrm{FeCl} \\
\mathrm{Fe}(\mathrm{L}) \\
\mathrm{Fe}(\alpha, \delta, \gamma)\end{array}$ \\
\hline 1450 & 0.01 & $\begin{array}{l}\text { Gas } \\
\text { Liquid } \\
\text { Solid } \\
\end{array}$ & $\begin{array}{l}\mathrm{SiCl}_{2} \\
\mathrm{Si}(\mathrm{L}) \\
\mathrm{Si}(\mathrm{S}) \\
\end{array}$ & $\begin{array}{l}\mathrm{BCl}_{3}, \mathrm{BCl} \\
\mathrm{B}(\mathrm{L}) \\
\mathrm{B}(\mathrm{S})\end{array}$ & $\begin{array}{l}\mathrm{P}_{2} \\
\mathrm{P}(\mathrm{L}) \\
\mathrm{P}(\mathrm{cr}) \\
\end{array}$ & $\begin{array}{l}\mathrm{Si}_{2} \mathrm{C} \\
-- \\
\mathrm{SiC}(\mathrm{B}) \\
\end{array}$ & $\begin{array}{l}\mathrm{FeCl}_{2} \\
\mathrm{Fe}(\mathrm{L}), \mathrm{FeCl}_{2}(\mathrm{~L}) \\
\mathrm{Fe}(\alpha, \delta, \gamma)\end{array}$ \\
\hline 1450 & 0.1 & $\begin{array}{l}\text { Gas } \\
\text { Liquid } \\
\text { Solid }\end{array}$ & $\begin{array}{l}\mathrm{SiCl}_{2}, \mathrm{SiCl}_{4} \\
\mathrm{Si}(\mathrm{L}) \\
\mathrm{Si}(\mathrm{S})\end{array}$ & $\begin{array}{l}\mathrm{BCl}_{3} \\
\mathrm{~B}(\mathrm{~L}) \\
\mathrm{B}(\mathrm{S})\end{array}$ & $\begin{array}{l}\mathrm{P}_{2} \\
\mathrm{P}(\mathrm{L}) \\
\mathrm{P}(\mathrm{cr})\end{array}$ & $\begin{array}{l}\mathrm{Si}_{2} \mathrm{C} \\
- \\
\mathrm{SiC}(\mathrm{B})\end{array}$ & $\begin{array}{l}\mathrm{FeCl}_{2} \\
\mathrm{FeCl}(\mathrm{L}), \mathrm{Fe}(\mathrm{L}) \\
\mathrm{Fe}(\alpha, \delta, \gamma)\end{array}$ \\
\hline 1450 & 1.0 & $\begin{array}{l}\text { Gas } \\
\text { Liquid } \\
\text { Solid } \\
\end{array}$ & $\begin{array}{l}\mathrm{SiCl}_{4}, \mathrm{SiCl}_{2} \\
\mathrm{Si}(\mathrm{L}) \\
\mathrm{Si}(\mathrm{S})\end{array}$ & $\begin{array}{l}\mathrm{BCl}_{3} \\
\mathrm{~B}(\mathrm{~L}) \\
\mathrm{B}(\mathrm{S})\end{array}$ & $\begin{array}{l}\mathrm{P}_{2} \\
\mathrm{P}(\mathrm{L}) \\
\mathrm{P}(\mathrm{cr}) \\
\end{array}$ & $\begin{array}{l}\mathrm{Si}_{2} \mathrm{C} \\
- \\
\mathrm{SiC}(\mathrm{B})\end{array}$ & $\begin{array}{l}\mathrm{FeCl}_{2} \\
\mathrm{FeCl}(\mathrm{L}) \\
\mathrm{Fe}(\alpha, \delta, \gamma)\end{array}$ \\
\hline 1550 & 0.001 & $\begin{array}{l}\text { Gas } \\
\text { Liquid } \\
\text { Solid }\end{array}$ & $\begin{array}{l}\mathrm{SiCl}_{2} \\
\mathrm{Si}(\mathrm{L}) \\
\mathrm{Si}(\mathrm{S}), \mathrm{SiC}(\mathrm{B})\end{array}$ & $\begin{array}{l}\mathrm{BCl} \\
\mathrm{B}(\mathrm{L}) \\
\mathrm{B}(\mathrm{S})\end{array}$ & $\begin{array}{l}\mathrm{P}_{2}, \mathrm{P} \\
\mathrm{P}(\mathrm{L}) \\
\mathrm{P}(\mathrm{cr})\end{array}$ & $\begin{array}{l}\mathrm{Si}_{2} \mathrm{C} \\
-- \\
\mathrm{SiC}(\mathrm{B})\end{array}$ & $\begin{array}{l}\mathrm{FeCl} \\
\mathrm{Fe}(\mathrm{L}) \\
\mathrm{Fe}(\alpha, \delta, \gamma)\end{array}$ \\
\hline 1550 & 0.01 & $\begin{array}{l}\text { Gas } \\
\text { Liquid } \\
\text { Solid }\end{array}$ & $\begin{array}{l}\mathrm{SiCl}_{2} \\
\mathrm{Si}(\mathrm{L}) \\
\mathrm{Si}(\mathrm{S}), \mathrm{SiC}(\mathrm{B})\end{array}$ & $\begin{array}{l}\mathrm{BCl}, \mathrm{BCl}_{3} \\
\mathrm{~B}(\mathrm{~L}) \\
\mathrm{B}(\mathrm{S})\end{array}$ & $\begin{array}{l}\mathrm{P}_{2} \\
\mathrm{P}(\mathrm{L}) \\
\mathrm{P}(\mathrm{cr})\end{array}$ & $\begin{array}{l}\mathrm{Si}_{2} \mathrm{C} \\
-- \\
\mathrm{SiC}(\mathrm{B})\end{array}$ & $\begin{array}{l}\mathrm{FeCl}_{2} \\
\mathrm{Fe}(\mathrm{L}), \mathrm{FeCl}_{2}(\mathrm{~L}) \\
\mathrm{Fe}(\alpha, \delta, \gamma)\end{array}$ \\
\hline 1550 & 0.1 & $\begin{array}{l}\text { Gas } \\
\text { Liquid } \\
\text { Solid } \\
\end{array}$ & $\begin{array}{l}\mathrm{SiCl}_{2} \\
\mathrm{Si}(\mathrm{L}) \\
\mathrm{Si}(\mathrm{S}), \mathrm{SiC}(\mathrm{B}) \\
\end{array}$ & $\begin{array}{l}\mathrm{BCl}_{3} \\
\mathrm{~B}(\mathrm{~L}) \\
\mathrm{B}(\mathrm{S}) \\
\end{array}$ & $\begin{array}{l}\mathrm{P}_{2} \\
\mathrm{P}(\mathrm{L}) \\
\mathrm{P}(\mathrm{cr}) \\
\end{array}$ & $\begin{array}{l}\mathrm{Si}_{2} \mathrm{C} \\
-- \\
\mathrm{SiC}(\mathrm{B}) \\
\end{array}$ & $\begin{array}{l}\mathrm{FeCl}_{2} \\
\mathrm{FeCl}(\mathrm{L}) \\
\mathrm{Fe}(\alpha, \delta, \gamma) \\
\end{array}$ \\
\hline 1550 & 1.0 & $\begin{array}{l}\text { Gas } \\
\text { Liquid } \\
\text { Solid } \\
\end{array}$ & $\begin{array}{l}\mathrm{SiCl}_{2}, \mathrm{SiCl}_{4} \\
\mathrm{Si}(\mathrm{L}) \\
\mathrm{Si}(\mathrm{S}), \mathrm{SiC}(\mathrm{B})\end{array}$ & $\begin{array}{l}\mathrm{BCl}_{3} \\
\mathrm{~B}(\mathrm{~L}) \\
\mathrm{B}(\mathrm{S}) \\
\end{array}$ & $\begin{array}{l}\mathrm{P}_{2}, \mathrm{PCl} \\
\mathrm{P}(\mathrm{L}) \\
\mathrm{P}(\mathrm{cr})\end{array}$ & $\begin{array}{l}\mathrm{Si}_{2} \mathrm{C} \\
- \\
\mathrm{SiC}(\mathrm{B}) \\
\end{array}$ & $\begin{array}{l}\mathrm{FeCl}_{2} \\
\mathrm{FeCl}_{2}(\mathrm{~L}) \\
\mathrm{Fe}(\alpha, \delta, \gamma)\end{array}$ \\
\hline 1650 & 0.001 & $\begin{array}{l}\text { Gas } \\
\text { Liquid } \\
\text { Solid }\end{array}$ & $\begin{array}{l}\mathrm{SiCl}_{2} \\
\mathrm{Si}(\mathrm{L}) \\
\mathrm{Si}(\mathrm{S}), \mathrm{SiC}(\mathrm{B})\end{array}$ & $\begin{array}{l}\mathrm{BCl} \\
\mathrm{B}(\mathrm{L}) \\
\mathrm{B}(\mathrm{S})\end{array}$ & $\begin{array}{l}\mathrm{P}_{2}, \mathrm{P} \\
\mathrm{P}(\mathrm{L}) \\
\mathrm{P}(\mathrm{cr})\end{array}$ & $\begin{array}{l}\mathrm{Si}_{2} \mathrm{C} \\
- \\
\mathrm{SiC}(\mathrm{B})\end{array}$ & $\begin{array}{l}\mathrm{FeCl}_{2} \\
\mathrm{Fe}(\mathrm{L}) \\
\mathrm{Fe}(\alpha, \delta, \gamma)\end{array}$ \\
\hline 1650 & 0.01 & $\begin{array}{l}\text { Gas } \\
\text { Liquid } \\
\text { Solid } \\
\end{array}$ & $\begin{array}{l}\mathrm{SiCl}_{2} \\
\mathrm{Si}(\mathrm{L}) \\
\mathrm{Si}(\mathrm{S}), \mathrm{SiC}(\mathrm{B})\end{array}$ & $\begin{array}{l}\mathrm{BCl} \\
\mathrm{B}(\mathrm{L}) \\
\mathrm{B}(\mathrm{S}) \\
\end{array}$ & $\begin{array}{l}\mathrm{P}_{2}, \mathrm{P} \\
\mathrm{P}(\mathrm{L}) \\
\mathrm{P}(\mathrm{cr})\end{array}$ & $\begin{array}{l}\mathrm{Si}_{2} \mathrm{C} \\
-- \\
\mathrm{SiC}(\mathrm{B}) \\
\end{array}$ & $\begin{array}{l}\mathrm{FeCl}_{2} \\
\mathrm{Fe}(\mathrm{L}), \mathrm{FeCl}_{2}(\mathrm{~L}) \\
\mathrm{Fe}(\alpha, \delta, \gamma)\end{array}$ \\
\hline 1650 & 0.1 & $\begin{array}{l}\text { Gas } \\
\text { Liquid } \\
\text { Solid } \\
\end{array}$ & $\begin{array}{l}\mathrm{SiCl}_{2} \\
\mathrm{Si}(\mathrm{L}) \\
\mathrm{Si}(\mathrm{S}), \mathrm{SiC}(\mathrm{B})\end{array}$ & $\begin{array}{l}\mathrm{BCl}_{3}, \mathrm{BCl} \\
\mathrm{B}(\mathrm{L}) \\
\mathrm{B}(\mathrm{S})\end{array}$ & $\begin{array}{l}\mathrm{P}_{2}, \mathrm{P} \\
\mathrm{P}(\mathrm{L}) \\
\mathrm{P}(\mathrm{cr})\end{array}$ & $\begin{array}{l}\mathrm{Si}_{2} \mathrm{C} \\
-- \\
\mathrm{SiC}(\mathrm{B}) \\
\end{array}$ & $\begin{array}{l}\mathrm{FeCl}_{2} \\
\mathrm{FeCl}_{2}(\mathrm{~L}) \\
\mathrm{Fe}(\alpha, \delta, \gamma) \\
\end{array}$ \\
\hline 1650 & 1.0 & $\begin{array}{l}\text { Gas } \\
\text { Liquid } \\
\text { Solid }\end{array}$ & $\begin{array}{l}\mathrm{SiCl}_{2}, \mathrm{SiCl}_{4} \\
\mathrm{Si}(\mathrm{L}) \\
\mathrm{Si}(\mathrm{S}), \mathrm{SiC}(\mathrm{B})\end{array}$ & $\begin{array}{l}\mathrm{BCl}_{3} \\
\mathrm{~B}(\mathrm{~L}) \\
\mathrm{B}(\mathrm{S})\end{array}$ & $\begin{array}{l}\mathrm{P}_{2}, \mathrm{PCl}, \mathrm{P} \\
\mathrm{P}(\mathrm{L}) \\
\mathrm{P}(\mathrm{cr})\end{array}$ & $\begin{array}{l}\mathrm{Si}_{2} \mathrm{C} \\
-- \\
\mathrm{SiC}(\mathrm{B})\end{array}$ & $\begin{array}{l}\mathrm{FeCl}_{2} \\
\mathrm{FeCl}(\mathrm{L}) \\
\mathrm{Fe}(\alpha, \delta, \gamma) \\
\end{array}$ \\
\hline
\end{tabular}

* Chemical species are listed for each phase in order of decreasing mole fraction as a function of temperature and pressure. If multiple species are listed, each represents at least $\sim 20 \%$ of the element in that phase. 


\section{I. $\mathrm{NH}_{3}$ Addition}

Ammonia is generally considered more reactive than $\mathrm{N}_{2}$, and is worth examining as an alternate nitrogen-containing system. The results in Figure 25 through Figure 27 and Table 12 show significant formation of volatile PN, especially for lower pressures. This is similar to the results for $\mathrm{P}$ removal in section III.B. for air, although $\mathrm{NH}_{3}$ appears to give somewhat more volatile $\mathrm{PN}$ at moderate pressures. In the presence of $\mathrm{NH}_{3}, \mathrm{~B}$ forms a lot of $\mathrm{BN}(\mathrm{cr})$ with almost no volatile products. Carbon stays in the solid phase as silicon carbide for the range of conditions explored, and $\mathrm{Fe}$ is physically volatilized at higher temperatures and low pressures. Some silicon is lost by formation of $\mathrm{Si}_{3} \mathrm{~N}_{4}(\mathrm{~A})$ and $\mathrm{SiC}(\mathrm{B})$, but no significant amount of silicon-containing volatiles are formed. Most of the gas phase is composed of $\mathrm{H}_{2}$ and $\mathrm{N}_{2}$ formed from the input $\mathrm{NH}_{3}$. Ammonia thus appears to be a good candidate for $\mathrm{P}$ removal, and possibly $\mathrm{B}$ and $\mathrm{C}$ if the solids can be separated from the silicon. 

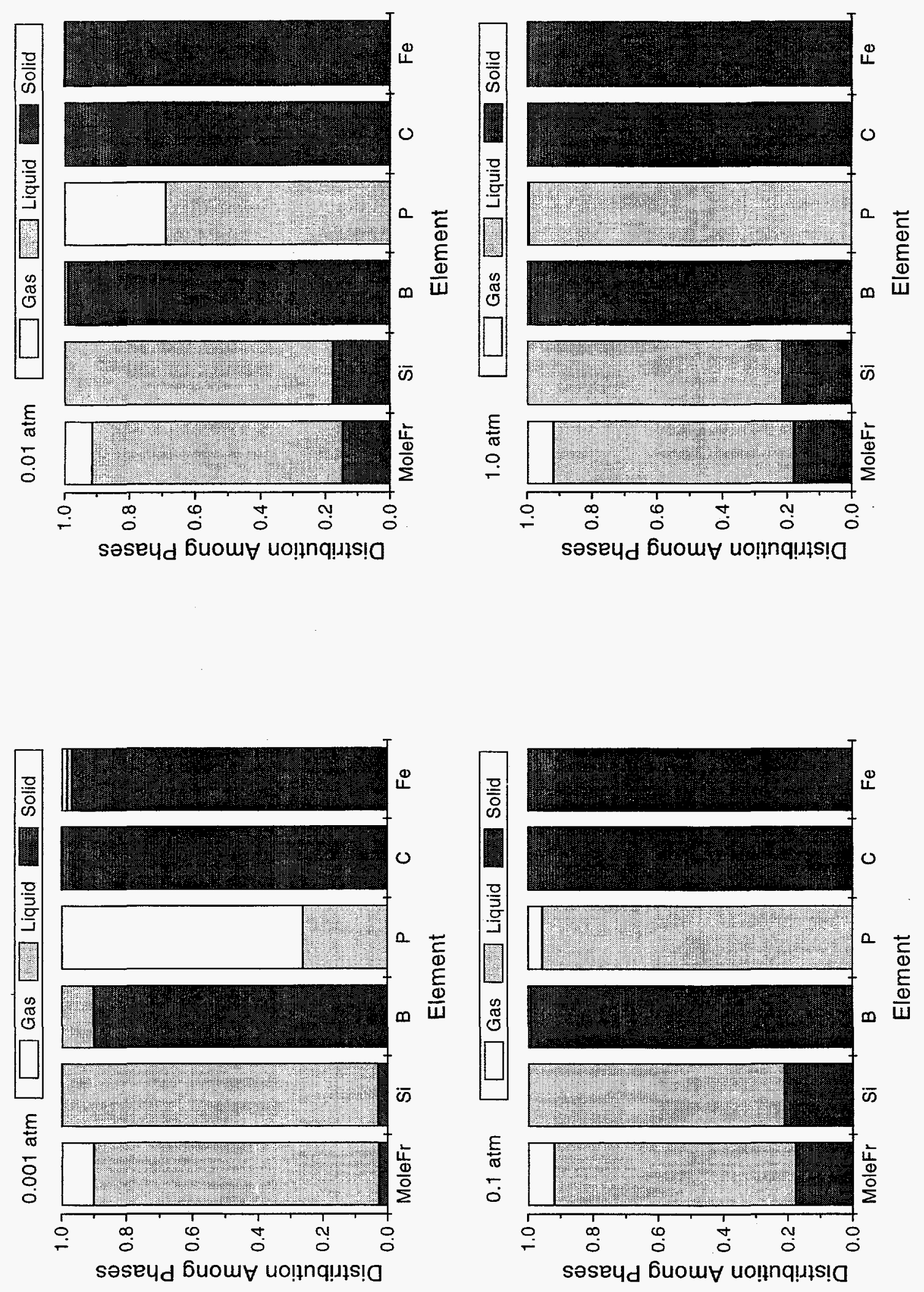

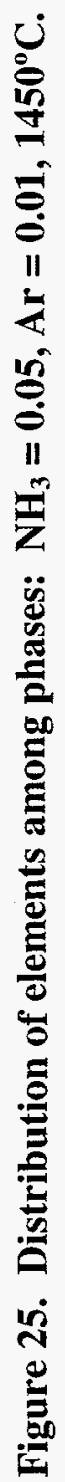



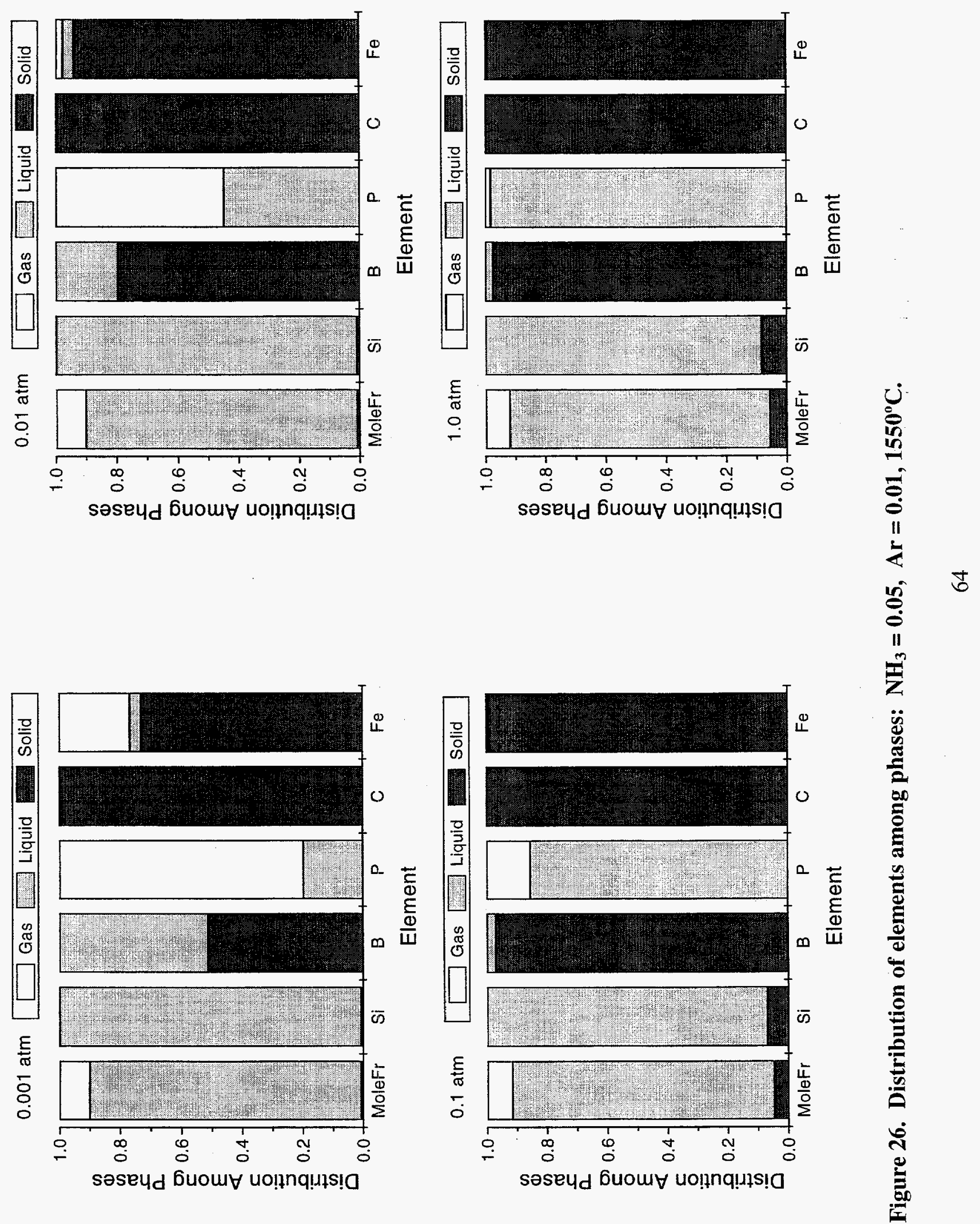

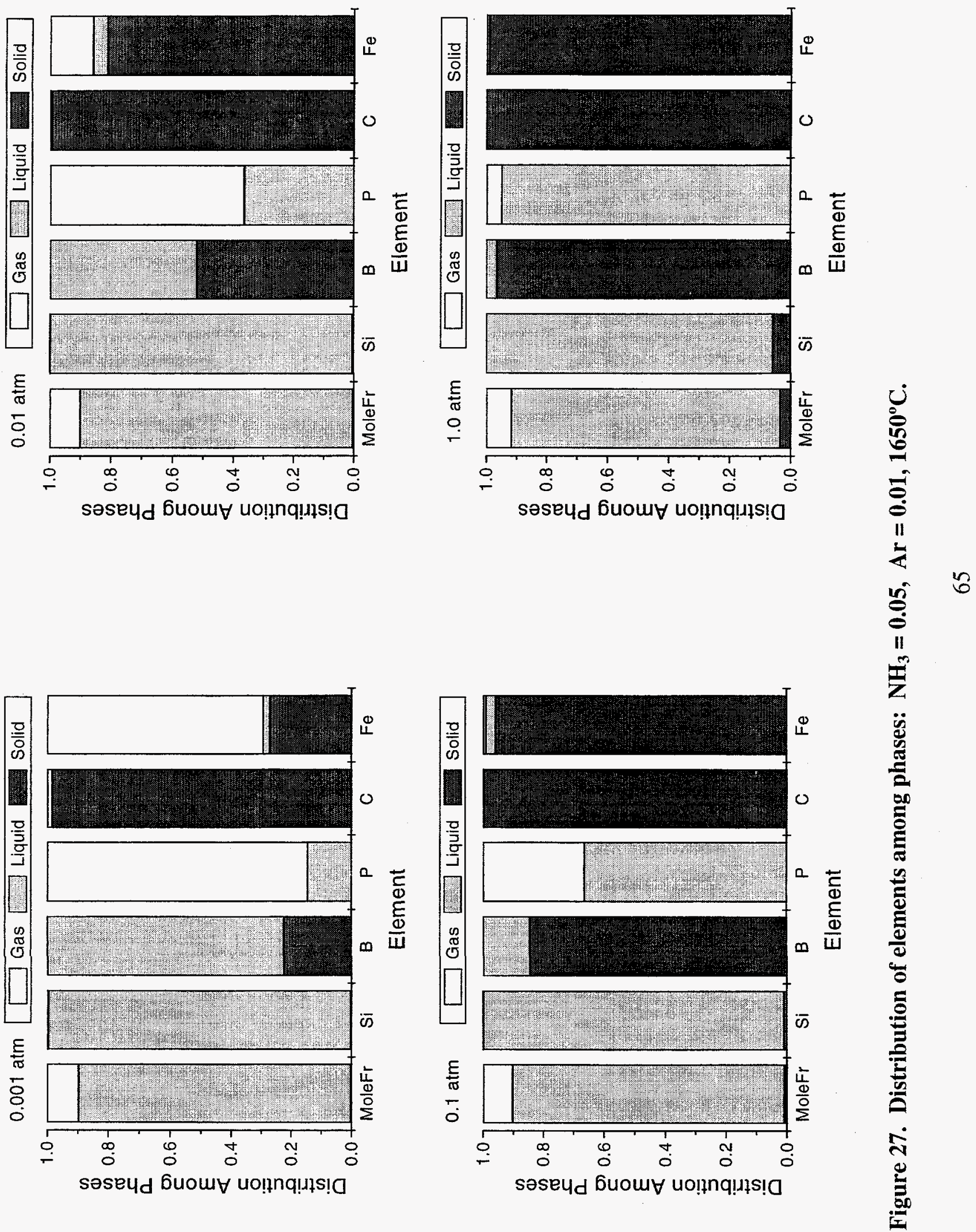
Table 12. Dominant* chemical species for silicon and impurities with $\mathrm{NH}_{3} / \mathrm{Ar}$ addition.

\begin{tabular}{|c|c|c|c|c|c|c|c|}
\hline $\begin{array}{l}\text { Temp. } \\
\left({ }^{\circ} \mathrm{C}\right)\end{array}$ & $\begin{array}{l}\text { Pressure } \\
\text { (atm) }\end{array}$ & Phase & $\mathrm{Si}$ & B & $P$ & $\mathrm{C}$ & $\mathrm{Fe}$ \\
\hline 1450 & 0.001 & $\begin{array}{l}\text { Gas } \\
\text { Liquid } \\
\text { Solid }\end{array}$ & $\begin{array}{l}\mathrm{Si} \\
\mathrm{Si}(\mathrm{L}) \\
\mathrm{Si}(\mathrm{S})\end{array}$ & $\begin{array}{l}\mathrm{BH}_{3} \\
\mathrm{~B}(\mathrm{~L}) \\
\mathrm{BN}(\mathrm{cr})\end{array}$ & $\begin{array}{l}\mathrm{PN} \\
\mathrm{P}(\mathrm{L}) \\
\mathrm{P}(\mathrm{cr})\end{array}$ & $\begin{array}{l}\mathrm{HCN} \\
- \\
\mathrm{SiC}(\mathrm{B})\end{array}$ & $\begin{array}{l}\mathrm{Fe} \\
\mathrm{Fe}(\mathrm{L}) \\
\mathrm{Fe}(\alpha, \delta, \gamma)\end{array}$ \\
\hline 1450 & $\begin{array}{l}0.01- \\
0.1\end{array}$ & $\begin{array}{l}\text { Gas } \\
\text { Liquid } \\
\text { Solid } \\
\end{array}$ & $\begin{array}{l}\text { SiNH, Si } \\
\mathrm{Si}(\mathrm{L}) \\
\mathrm{Si}(\mathrm{S})\end{array}$ & $\begin{array}{l}\mathrm{BH}_{3} \\
\mathrm{~B}(\mathrm{~L}) \\
\mathrm{BN}(\mathrm{cr}) \\
\end{array}$ & $\begin{array}{l}\mathrm{PN} \\
\mathrm{P}(\mathrm{L}) \\
\mathrm{P}(\mathrm{cr})\end{array}$ & $\begin{array}{l}\mathrm{HCN}, \mathrm{CHP} \\
-- \\
\mathrm{SiC}(\mathrm{B}) \\
\end{array}$ & $\begin{array}{l}\mathrm{Fe} \\
\mathrm{Fe}(\mathrm{L}) \\
\mathrm{Fe}(\alpha, \delta, \gamma)\end{array}$ \\
\hline 1450 & 1.0 & $\begin{array}{l}\text { Gas } \\
\text { Liquid } \\
\text { Solid }\end{array}$ & $\begin{array}{l}\mathrm{SiNH} \\
\mathrm{Si}(\mathrm{L}) \\
\mathrm{Si}(\mathrm{S}) \\
\end{array}$ & $\begin{array}{l}\mathrm{BH}_{3} \\
\mathrm{~B}(\mathrm{~L}) \\
\mathrm{BN}(\mathrm{cr})\end{array}$ & $\begin{array}{l}\mathrm{PN} \\
\mathrm{P}(\mathrm{L}) \\
\mathrm{P}(\mathrm{cr})\end{array}$ & $\begin{array}{l}\mathrm{CH}_{4} \\
-- \\
\mathrm{SiC}(\mathrm{B})\end{array}$ & $\begin{array}{l}\mathrm{Fe} \\
\mathrm{Fe}(\mathrm{L}) \\
\mathrm{Fe}(\alpha, \delta, \gamma)\end{array}$ \\
\hline 1550 & 0.001 & $\begin{array}{l}\text { Gas } \\
\text { Liquid } \\
\text { Solid } \\
\end{array}$ & $\begin{array}{l}\mathrm{Si} \\
\mathrm{Si}(\mathrm{L}) \\
\mathrm{Si}(\mathrm{S}) \\
\end{array}$ & $\begin{array}{l}\mathrm{B}, \mathrm{BH}_{3} \\
\mathrm{~B}(\mathrm{~L}) \\
\mathrm{BN}(\mathrm{cr})\end{array}$ & $\begin{array}{l}\mathrm{PN} \\
\mathrm{P}(\mathrm{L}) \\
\mathrm{P}(\mathrm{cr})\end{array}$ & $\begin{array}{l}\mathrm{HCN}, \mathrm{Si}_{2} \mathrm{C} \\
-- \\
\mathrm{SiC}(\mathrm{B}) \\
\end{array}$ & $\begin{array}{l}\mathrm{Fe} \\
\mathrm{Fe}(\mathrm{L}) \\
\mathrm{Fe}(\alpha, \delta, \gamma)\end{array}$ \\
\hline 1550 & 0.01 & $\begin{array}{l}\text { Gas } \\
\text { Liquid } \\
\text { Solid }\end{array}$ & $\begin{array}{l}\mathrm{Si}, \mathrm{SiNH} \\
\mathrm{Si}(\mathrm{L}) \\
\mathrm{Si}(\mathrm{S})\end{array}$ & $\begin{array}{l}\mathrm{BH}_{3} \\
\mathrm{~B}(\mathrm{~L}) \\
\mathrm{BN}(\mathrm{cr})\end{array}$ & $\begin{array}{l}\mathrm{PN} \\
\mathrm{P}(\mathrm{L}) \\
\mathrm{P}(\mathrm{cr})\end{array}$ & $\begin{array}{l}\mathrm{HCN} \\
-- \\
\mathrm{SiC}(\mathrm{B})\end{array}$ & $\begin{array}{l}\mathrm{Fe} \\
\mathrm{Fe}(\mathrm{L}) \\
\mathrm{Fe}(\alpha, \delta, \gamma)\end{array}$ \\
\hline 1550 & 0.1 & $\begin{array}{l}\text { Gas } \\
\text { Liquid } \\
\text { Solid }\end{array}$ & $\begin{array}{l}\mathrm{SiNH}, \mathrm{Si} \\
\mathrm{Si}(\mathrm{L}) \\
\mathrm{Si}(\mathrm{S}), \mathrm{Si}_{3} \mathrm{~N}_{4}(\mathrm{~A})\end{array}$ & $\begin{array}{l}\mathrm{BH}_{3} \\
\mathrm{~B}(\mathrm{~L}) \\
\mathrm{BN}(\mathrm{cr})\end{array}$ & $\begin{array}{l}\text { PN } \\
\mathrm{P}(\mathrm{L}) \\
\mathrm{P}(\mathrm{cr})\end{array}$ & $\begin{array}{l}\mathrm{HCN} \\
-- \\
\mathrm{SiC}(\mathrm{B})\end{array}$ & $\begin{array}{l}\mathrm{Fe} \\
\mathrm{Fe}(\mathrm{L}) \\
\mathrm{Fe}(\alpha, \delta, \gamma)\end{array}$ \\
\hline 1550 & 1.0 & $\begin{array}{l}\text { Gas } \\
\text { Liquid } \\
\text { Solid } \\
\end{array}$ & $\begin{array}{l}\mathrm{SiNH} \\
\mathrm{Si}(\mathrm{L}) \\
\mathrm{Si}(\mathrm{S}), \mathrm{Si}_{3} \mathrm{~N}_{4}(\mathrm{~A})\end{array}$ & $\begin{array}{l}\mathrm{BH}_{3} \\
\mathrm{~B}(\mathrm{~L}) \\
\mathrm{BN}(\mathrm{cr})\end{array}$ & $\begin{array}{l}\mathrm{PN} \\
\mathrm{P}(\mathrm{L}) \\
\mathrm{P}(\mathrm{cr})\end{array}$ & $\begin{array}{l}\mathrm{HCN}, \mathrm{CH}_{4} \\
-- \\
\mathrm{SiC}(\mathrm{B}) \\
\end{array}$ & $\begin{array}{l}\mathrm{Fe} \\
\mathrm{Fe}(\mathrm{L}) \\
\mathrm{Fe}(\alpha, \delta, \gamma)\end{array}$ \\
\hline 1650 & 0.001 & $\begin{array}{l}\text { Gas } \\
\text { Liquid } \\
\text { Solid }\end{array}$ & $\begin{array}{l}\mathrm{Si} \\
\mathrm{Si}(\mathrm{L}) \\
\mathrm{Si}(\mathrm{S}), \mathrm{SiC}(\mathrm{B})\end{array}$ & $\begin{array}{l}\mathrm{B} \\
\mathrm{B}(\mathrm{L}) \\
\mathrm{BN}(\mathrm{cr}), \\
\mathrm{B}(\mathrm{S}) \\
\end{array}$ & $\begin{array}{l}\mathrm{PN} \\
\mathrm{P}(\mathrm{L}) \\
\mathrm{P}(\mathrm{cr})\end{array}$ & $\begin{array}{l}\mathrm{Si}_{2} \mathrm{C}, \mathrm{HCN} \\
-- \\
\mathrm{SiC}(\mathrm{B})\end{array}$ & $\begin{array}{l}\mathrm{Fe} \\
\mathrm{Fe}(\mathrm{L}) \\
\mathrm{Fe}(\alpha, \delta, \gamma)\end{array}$ \\
\hline 1650 & 0.01 & $\begin{array}{l}\text { Gas } \\
\text { Liquid } \\
\text { Solid } \\
\end{array}$ & $\begin{array}{l}\mathrm{Si} \\
\mathrm{Si}(\mathrm{L}) \\
\mathrm{Si}(\mathrm{S}), \mathrm{SiC}(\mathrm{B}) \\
\end{array}$ & $\begin{array}{l}\mathrm{BH}_{3} \\
\mathrm{~B}(\mathrm{~L}) \\
\mathrm{BN}(\mathrm{cr}) \\
\end{array}$ & $\begin{array}{l}\mathrm{PN} \\
\mathrm{P}(\mathrm{L}) \\
\mathrm{P}(\mathrm{cr})\end{array}$ & \begin{tabular}{|l}
$\mathrm{HCN}$ \\
-- \\
$\mathrm{SiC}(\mathrm{B})$ \\
\end{tabular} & $\begin{array}{l}\mathrm{Fe} \\
\mathrm{Fe}(\mathrm{L}) \\
\mathrm{Fe}(\alpha, \delta, \gamma)\end{array}$ \\
\hline 1650 & 0.1 & $\begin{array}{l}\text { Gas } \\
\text { Liquid } \\
\text { Solid }\end{array}$ & $\begin{array}{l}\mathrm{SiNH}, \mathrm{Si} \\
\mathrm{Si}(\mathrm{L}) \\
\mathrm{Si}(\mathrm{S}), \mathrm{Si}_{3} \mathrm{~N}_{4}(\mathrm{~A})\end{array}$ & $\begin{array}{l}\mathrm{BH}_{3} \\
\mathrm{~B}(\mathrm{~L}) \\
\mathrm{BN}(\mathrm{cr}) \\
\end{array}$ & $\begin{array}{l}\mathrm{PN} \\
\mathrm{P}(\mathrm{L}) \\
\mathrm{P}(\mathrm{cr})\end{array}$ & \begin{tabular}{|l|}
$\mathrm{HCN}$ \\
-- \\
$\mathrm{SiC}(\mathrm{B})$ \\
\end{tabular} & $\begin{array}{l}\mathrm{Fe} \\
\mathrm{Fe}(\mathrm{L}) \\
\mathrm{Fe}(\alpha, \delta, \gamma)\end{array}$ \\
\hline 1650 & 1.0 & $\begin{array}{l}\text { Gas } \\
\text { Liquid } \\
\text { Solid }\end{array}$ & $\begin{array}{l}\mathrm{SiNH} \\
\mathrm{Si}_{(\mathrm{L})} \\
\mathrm{Si}_{3} \mathrm{~N}_{4}(\mathrm{~A}), \mathrm{Si}(\mathrm{S}) \\
\end{array}$ & \begin{tabular}{|l|}
$\mathrm{BH}_{3}$ \\
$\mathrm{~B}(\mathrm{~L})$ \\
$\mathrm{BN}(\mathrm{cr})$ \\
\end{tabular} & $\begin{array}{l}\mathrm{PN} \\
\mathrm{P}(\mathrm{L}) \\
\mathrm{P}(\mathrm{cr}) \\
\end{array}$ & $\begin{array}{l}\mathrm{HCN} \\
-- \\
\mathrm{SiC}(\mathrm{B}) \\
\end{array}$ & $\begin{array}{l}\mathrm{Fe} \\
\mathrm{Fe}(\mathrm{L}) \\
\mathrm{Fe}(\alpha, \delta, \gamma)\end{array}$ \\
\hline
\end{tabular}

* Chemical species are listed for each phase in order of decreasing mole fraction as a function of temperature and pressure. If multiple species are listed, each represents at least $\sim 20 \%$ of the element in that phase. 


\section{J. $\mathrm{NH}_{4} \mathrm{OH}$ Addition}

Ammonium hydroxide can be thought of as a solution of ammonia in water, and could provide an easy method of handling ammonia on a production scale. It is sold at various concentrations, and in the calculations a mixture of 0.015 moles of $\mathrm{NH}_{3}$ and 0.035 moles of $\mathrm{H}_{2} \mathrm{O}$ is used to represent a "30\% $\mathrm{NH}_{3}$ solution". Figure 28 through Figure 30 and Table 13 give the equilibrium results for this system. As expected, these results are a combination of the results for $\mathrm{H}_{2} \mathrm{O}$ and $\mathrm{NH}_{3}$ shown above in sections III.C. and I. Carbon and silicon react with oxygen, so their distributions among the phases for $\mathrm{NH}_{4} \mathrm{OH}$ match those for $\mathrm{H}_{2} \mathrm{O}$. Phosphorus reacts with nitrogen, so its behavior with $\mathrm{NH}_{4} \mathrm{OH}$ matches that for $\mathrm{NH}_{3}$. The boron reacts both with the water to form gas-phase $\mathrm{HBO}$ and with ammonia to form $\mathrm{BN}(\mathrm{cr})$. Overall, especially at low pressure and higher temperature, $\mathrm{NH}_{4} \mathrm{OH}$ appears to be a good candidate for removal of $\mathrm{C}$ and $\mathrm{P}$ via chemical reaction, Fe by evaporation, with some $\mathrm{B}$. 

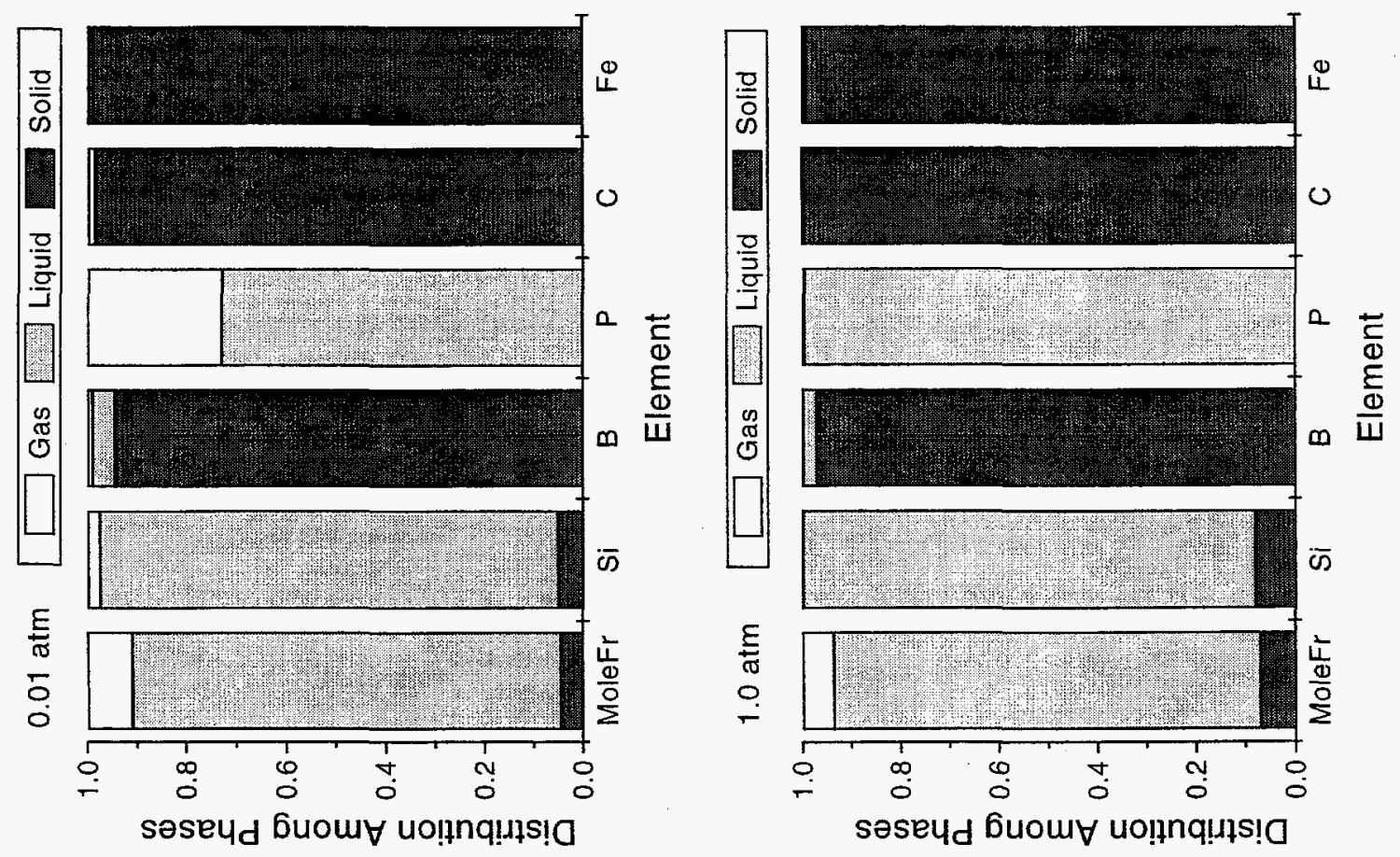

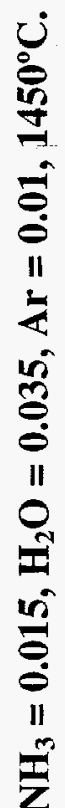
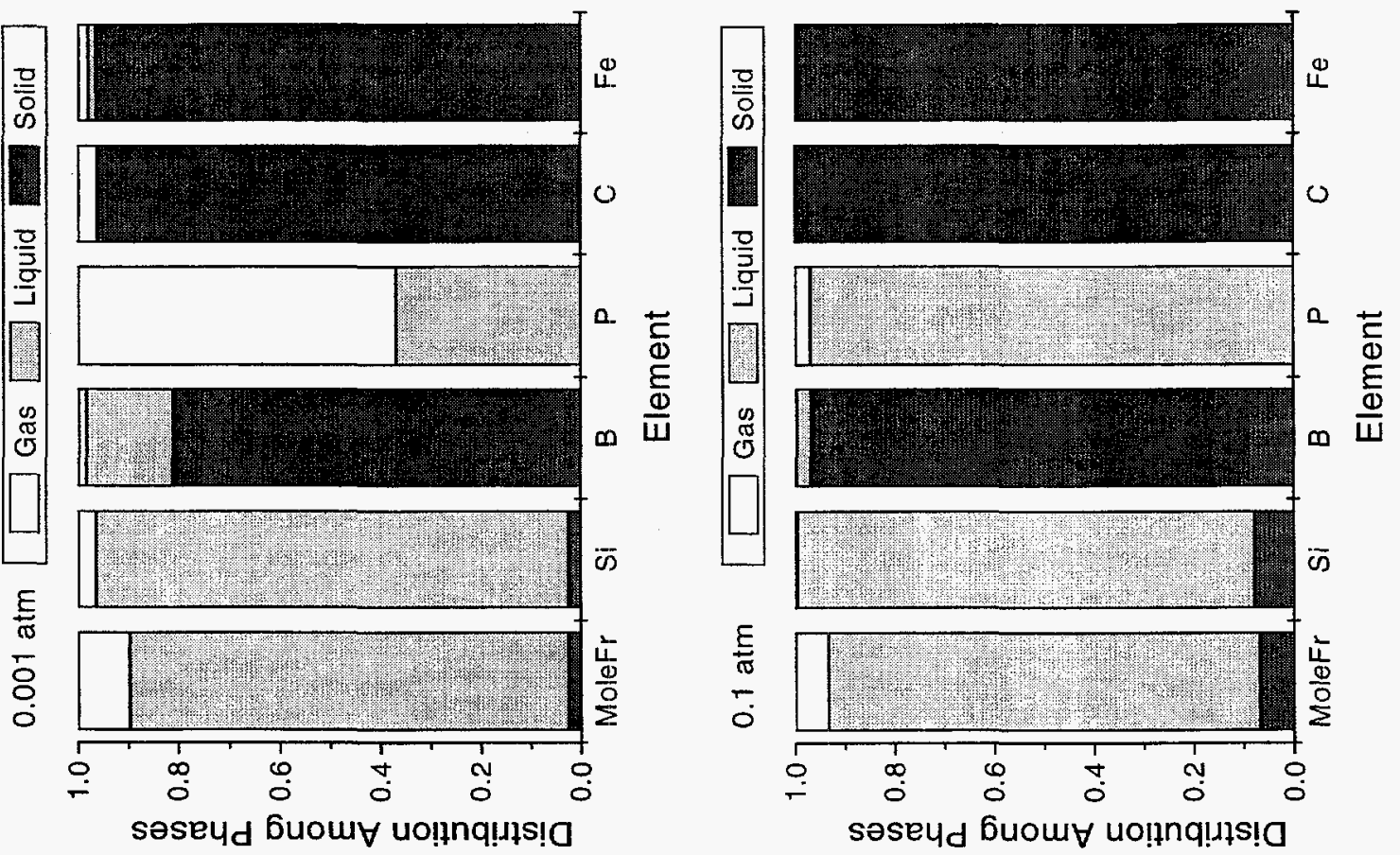

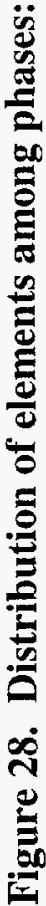



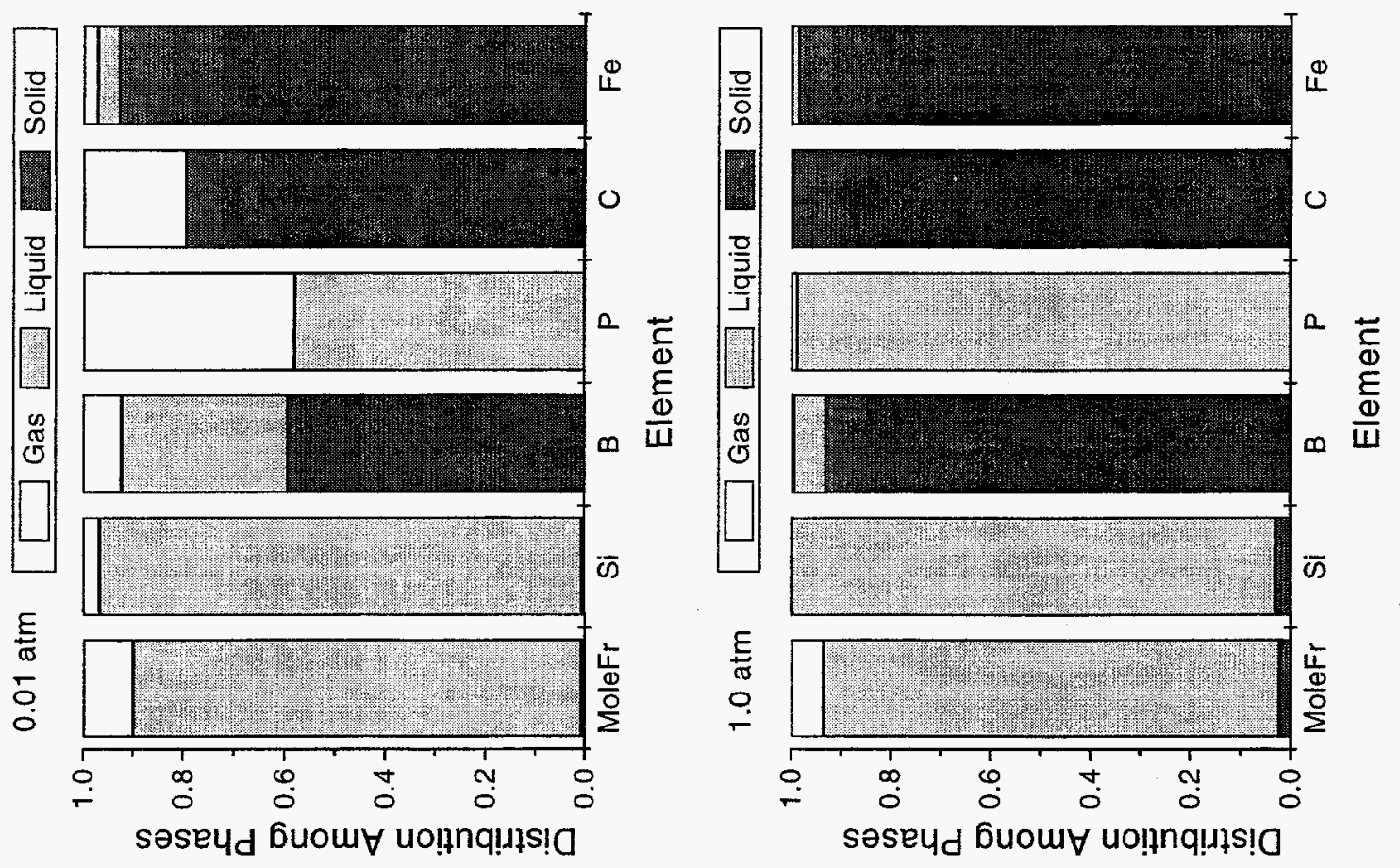

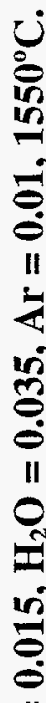
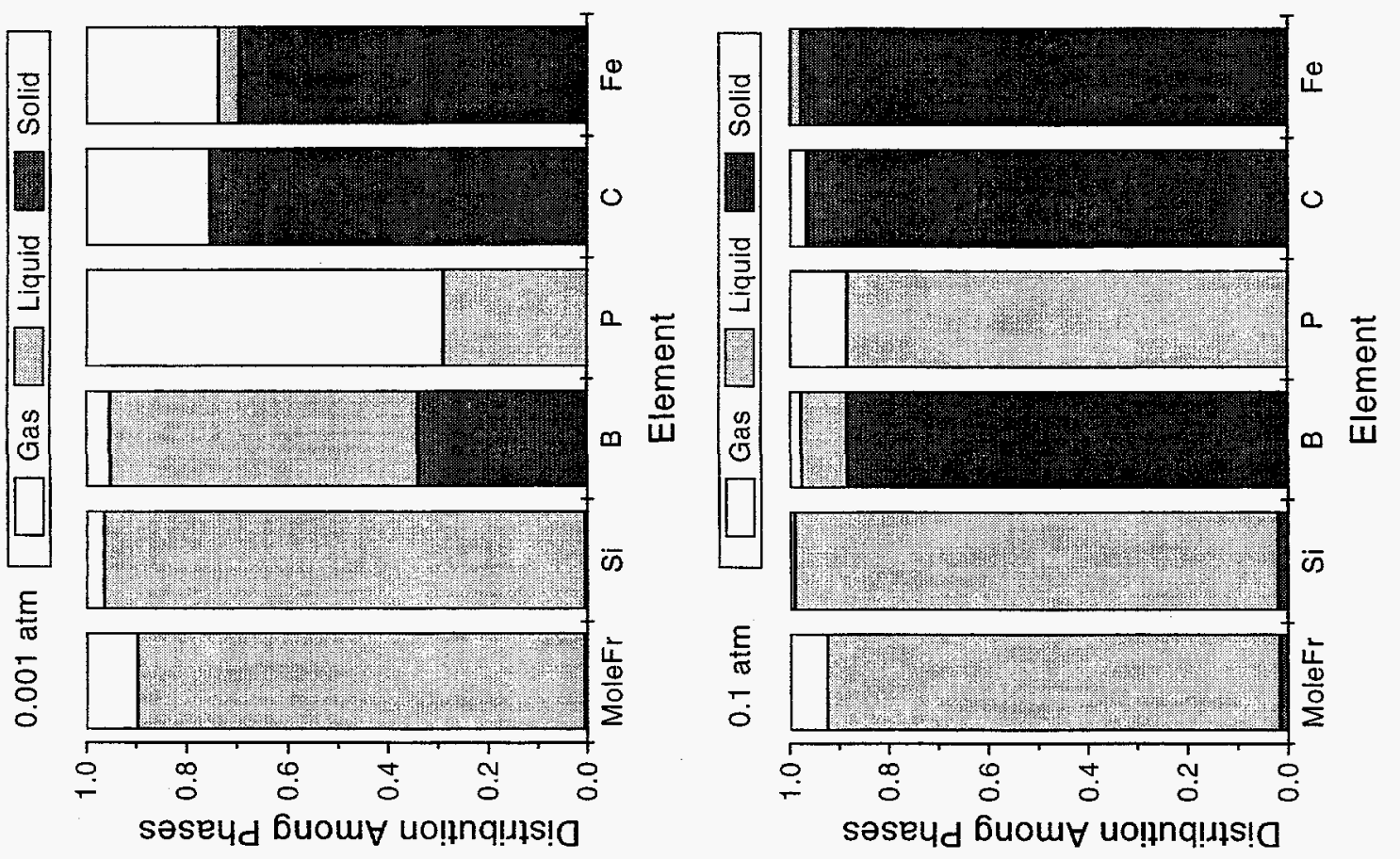

$\bar{z}$

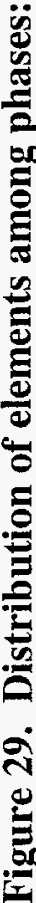



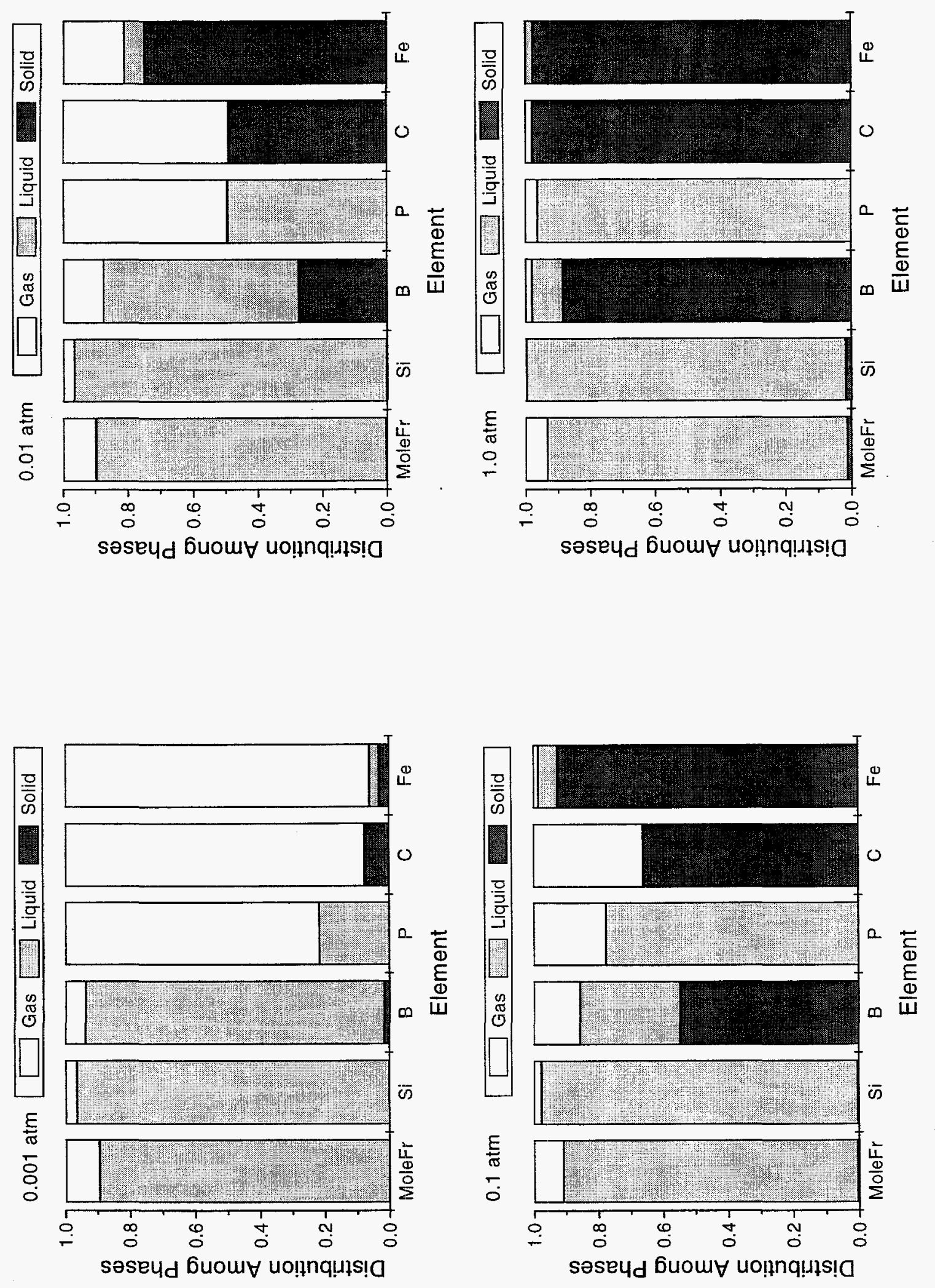
Table 13. Dominant* chemical species for silicon and impurities with $\mathrm{NH}_{3} / \mathrm{H}_{2} \mathrm{O} / \mathrm{Ar}$ addition.

\begin{tabular}{|c|c|c|c|c|c|c|c|}
\hline $\begin{array}{l}\text { Temp. } \\
\left({ }^{\circ} \mathrm{C}\right)\end{array}$ & $\begin{array}{l}\text { Pressure } \\
\text { (atm) }\end{array}$ & Phase & $\mathrm{Si}$ & B & $P$ & $\mathrm{C}$ & $\mathrm{Fe}$ \\
\hline 1450 & $\begin{array}{l}0.001- \\
1.0\end{array}$ & $\begin{array}{l}\text { Gas } \\
\text { Liquid } \\
\text { Solid }\end{array}$ & $\begin{array}{l}\mathrm{SiO} \\
\mathrm{Si}(\mathrm{L}) \\
\mathrm{Si}(\mathrm{S})\end{array}$ & $\begin{array}{l}\mathrm{HBO} \\
\mathrm{B}(\mathrm{L}) \\
\mathrm{BN}(\mathrm{cr})\end{array}$ & $\begin{array}{l}\mathrm{PN} \\
\mathrm{P}(\mathrm{L}) \\
\mathrm{P}(\mathrm{cr})\end{array}$ & $\begin{array}{l}\mathrm{CO} \\
- \\
\mathrm{SiC}(\mathrm{B})\end{array}$ & $\begin{array}{l}\mathrm{Fe} \\
\mathrm{Fe}(\mathrm{L}) \\
\mathrm{Fe}(\alpha, \delta, \gamma)\end{array}$ \\
\hline 1550 & 0.001 & $\begin{array}{l}\text { Gas } \\
\text { Liquid } \\
\text { Solid }\end{array}$ & $\begin{array}{l}\mathrm{SiO} \\
\mathrm{Si}(\mathrm{L}) \\
\mathrm{Si}(\mathrm{S})\end{array}$ & $\begin{array}{l}\mathrm{HBO} \\
\mathrm{B}(\mathrm{L}) \\
\mathrm{BN}(\mathrm{cr}), \mathrm{B}(\mathrm{S})\end{array}$ & $\begin{array}{l}\text { PN } \\
\mathrm{P}(\mathrm{L}) \\
\mathrm{P}(\mathrm{cr})\end{array}$ & $\begin{array}{l}\mathrm{CO} \\
-- \\
\mathrm{SiC}(\mathrm{B})\end{array}$ & $\begin{array}{l}\mathrm{Fe} \\
\mathrm{Fe}(\mathrm{L}) \\
\mathrm{Fe}(\alpha, \delta, \gamma)\end{array}$ \\
\hline 1550 & 0.01 & $\begin{array}{l}\text { Gas } \\
\text { Liquid } \\
\text { Solid }\end{array}$ & $\begin{array}{l}\mathrm{SiO} \\
\mathrm{Si}(\mathrm{L}) \\
\mathrm{Si}(\mathrm{S})\end{array}$ & $\begin{array}{l}\text { HBO } \\
\text { B(L) } \\
\text { BN(cr) }\end{array}$ & $\begin{array}{l}\text { PN } \\
P(L) \\
P(c r)\end{array}$ & $\begin{array}{l}\mathrm{CO} \\
-- \\
\mathrm{SiC}(\mathrm{B})\end{array}$ & $\begin{array}{l}\mathrm{Fe} \\
\mathrm{Fe}(\mathrm{L}) \\
\mathrm{Fe}(\alpha, \delta, \gamma)\end{array}$ \\
\hline 1550 & $\begin{array}{l}0.1- \\
1.0\end{array}$ & $\begin{array}{l}\text { Gas } \\
\text { Liquid } \\
\text { Solid }\end{array}$ & $\begin{array}{l}\mathrm{SiO} \\
\mathrm{Si}(\mathrm{L}) \\
\mathrm{Si}(\mathrm{S}), \mathrm{Si}_{3} \mathrm{~N}_{4}(\mathrm{~A})\end{array}$ & $\begin{array}{l}\mathrm{HBO} \\
\mathrm{B}(\mathrm{L}) \\
\mathrm{BN}(\mathrm{cr})\end{array}$ & $\begin{array}{l}\text { PN } \\
\text { P(L) } \\
\text { P(cr) }\end{array}$ & $\begin{array}{l}\mathrm{CO} \\
-- \\
\mathrm{SiC}(\mathrm{B})\end{array}$ & $\begin{array}{l}\mathrm{Fe} \\
\mathrm{Fe}(\mathrm{L}) \\
\mathrm{Fe}(\alpha, \delta, \gamma)\end{array}$ \\
\hline 1650 & 0.001 & $\begin{array}{l}\text { Gas } \\
\text { Liquid } \\
\text { Solid }\end{array}$ & $\begin{array}{l}\mathrm{SiO} \\
\mathrm{Si}(\mathrm{L}) \\
\mathrm{Si}(\mathrm{S}), \mathrm{SiC}(\mathrm{B})\end{array}$ & $\begin{array}{l}\mathrm{HBO} \\
\mathrm{B}(\mathrm{L}) \\
\mathrm{BN}(\mathrm{cr}), \mathrm{B}(\mathrm{S})\end{array}$ & $\begin{array}{l}\mathrm{PN} \\
\mathrm{P}(\mathrm{L}) \\
\mathrm{P}(\mathrm{cr})\end{array}$ & $\begin{array}{l}\mathrm{CO} \\
-- \\
\mathrm{SiC}(\mathrm{B})\end{array}$ & $\begin{array}{l}\mathrm{Fe} \\
\mathrm{Fe}(\mathrm{L}) \\
\mathrm{Fe}(\alpha, \delta, \gamma)\end{array}$ \\
\hline 1650 & $\begin{array}{l}0.01- \\
0.1\end{array}$ & $\begin{array}{l}\text { Gas } \\
\text { Liquid } \\
\text { Solid }\end{array}$ & $\begin{array}{l}\mathrm{SiO} \\
\mathrm{Si}(\mathrm{L}) \\
\mathrm{Si}(\mathrm{S})\end{array}$ & $\begin{array}{l}\mathrm{HBO} \\
\mathrm{B}(\mathrm{L}) \\
\mathrm{BN}(\mathrm{cr})\end{array}$ & $\begin{array}{l}\text { PN } \\
\text { P(L) } \\
\text { P(cr) }\end{array}$ & $\begin{array}{l}\mathrm{CO} \\
-- \\
\mathrm{SiC}(\mathrm{B})\end{array}$ & $\begin{array}{l}\mathrm{Fe} \\
\mathrm{Fe}(\mathrm{L}) \\
\mathrm{Fe}(\alpha, \delta, \gamma)\end{array}$ \\
\hline 1650 & 1.0 & $\begin{array}{l}\text { Gas } \\
\text { Liquid } \\
\text { Solid }\end{array}$ & $\begin{array}{l}\mathrm{SiO} \\
\mathrm{Si}(\mathrm{L}) \\
\mathrm{Si}(\mathrm{S}), \mathrm{Si}_{3} \mathrm{~N}_{4}(\mathrm{~A})\end{array}$ & $\begin{array}{l}\text { HBO } \\
\mathrm{B}(\mathrm{L}) \\
\mathrm{BN}(\mathrm{cr})\end{array}$ & $\begin{array}{l}\mathrm{PN} \\
\mathrm{P}(\mathrm{L}) \\
\mathrm{P}(\mathrm{cr})\end{array}$ & $\begin{array}{l}\mathrm{CO} \\
-- \\
\mathrm{SiC}(\mathrm{B})\end{array}$ & $\begin{array}{l}\mathrm{Fe} \\
\mathrm{Fe}(\mathrm{L}) \\
\mathrm{Fe}(\alpha, \delta, \gamma)\end{array}$ \\
\hline
\end{tabular}

* Chemical species are listed for each phase in order of decreasing mole fraction as a function of temperature and pressure. If multiple species are listed, each represents at least $\sim 20 \%$ of the element in that phase. 


\section{K. $\mathrm{NH}_{4} \mathrm{Cl}$ Addition}

Ammonium chloride is a salt of ammonia and hydrochloric acid that is a solid at room temperature, but decomposes upon heating above $\sim 350^{\circ} \mathrm{C}$. The results shown in Figure $31-$ Figure 33 and Table 14 are the expected combination of the results for $\mathrm{HCl}$ and $\mathrm{NH}_{3}$ in sections III.E. and I. In this case, the silicon reacts with the ammonia at the higher pressures to form noticeable amounts of solid $\mathrm{Si}_{3} \mathrm{~N}_{4}(\mathrm{~A})$, and with the $\mathrm{HCl}$ to form small amounts of volatile $\mathrm{SiCl}_{2}$. The carbon reacts with silicon to form $\mathrm{SiC}(\mathrm{B})$ for most of the conditions, with negligible amounts of volatile species such as $\mathrm{HCN}$. The gas phase is mostly composed of $\mathrm{H}_{2}, \mathrm{~N}_{2}$ and $\mathrm{HCl}$. The phosphorus reacts with ammonia to form $\mathrm{PN}$ in the gas, and the iron reacts to form $\mathrm{FeCl}_{2}$ vapor, especially at low pressures and high temperatures. The boron primarily forms $\mathrm{BN}(\mathrm{cr})$, especially at high pressures and low temperatures, but also forms some volatile boron chlorides $\left(\mathrm{BCl}, \mathrm{BHCl}_{2}\right.$ and $\left.\mathrm{BCl}_{3}\right)$, at low pressures and high temperatures. 

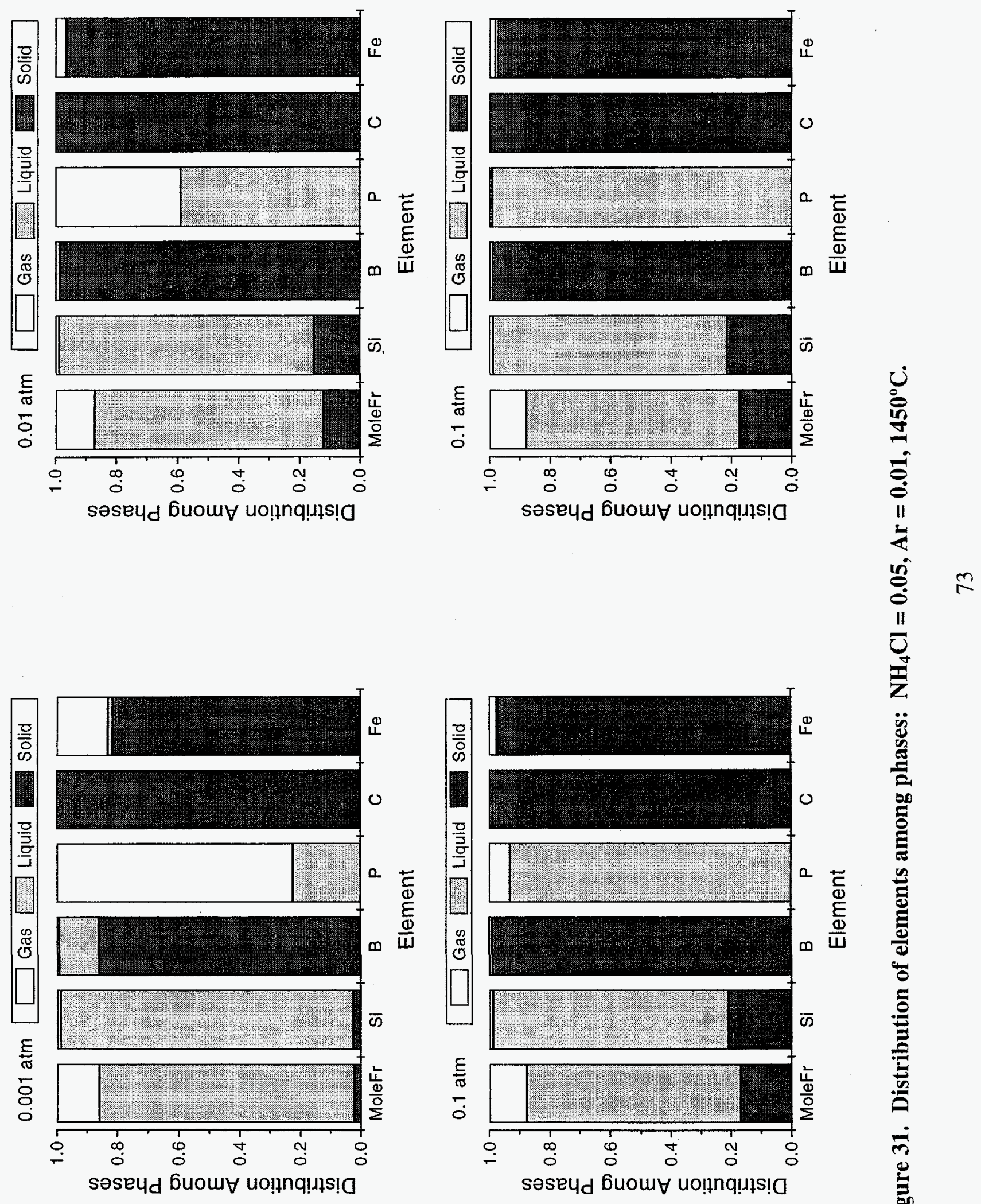

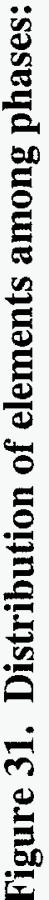



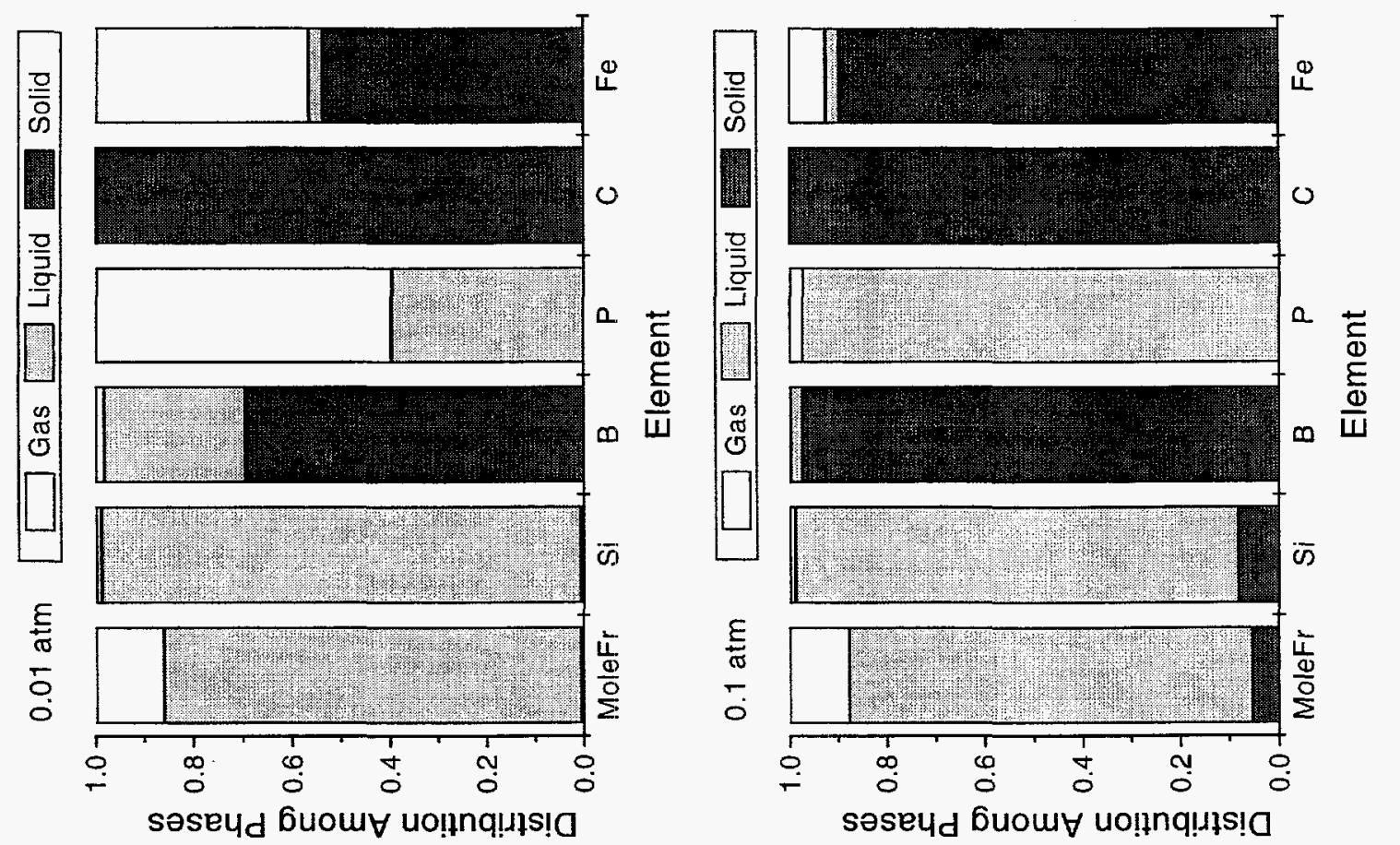

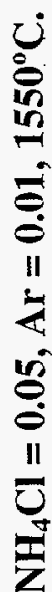
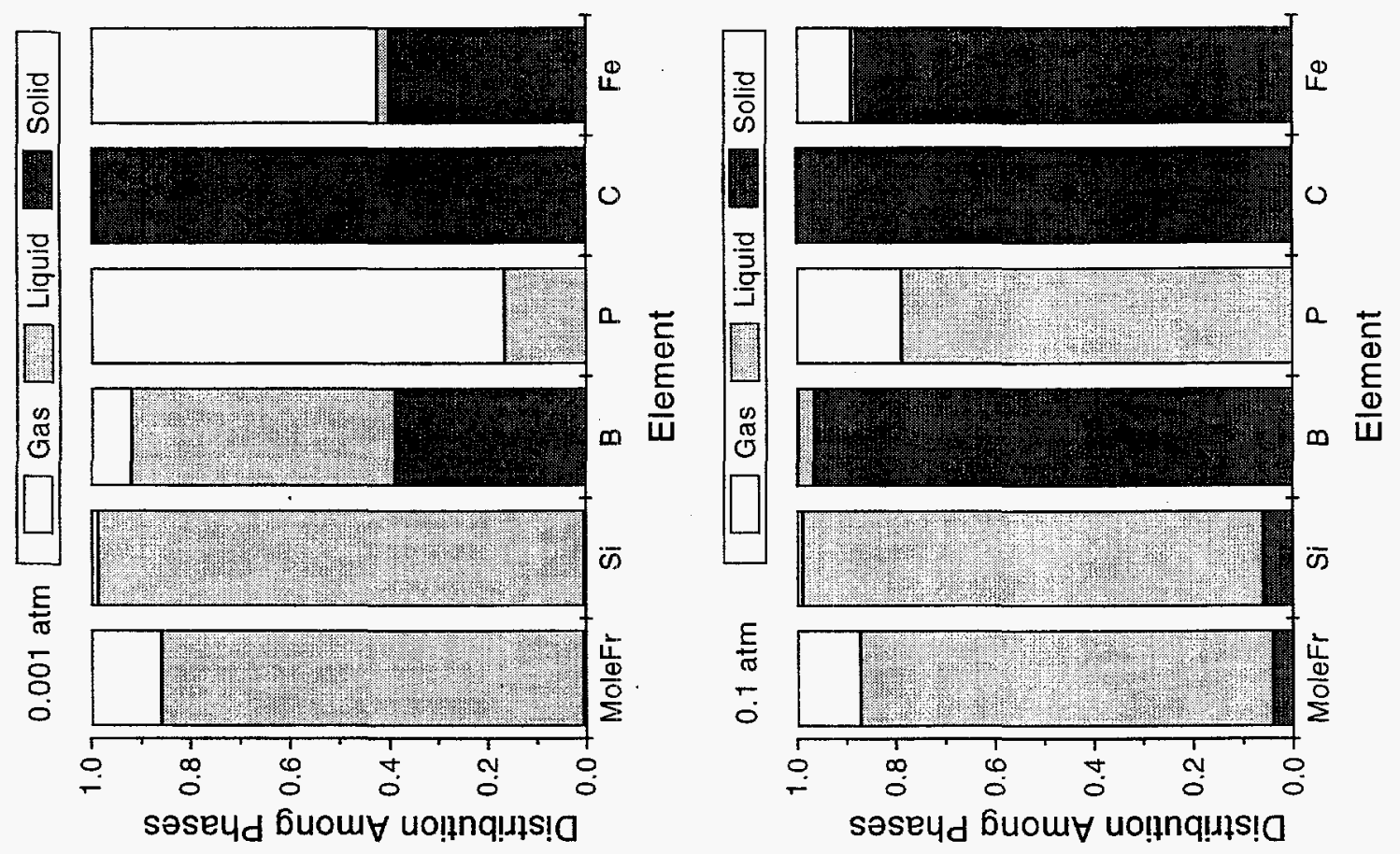

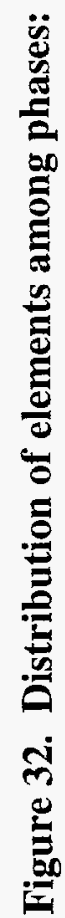



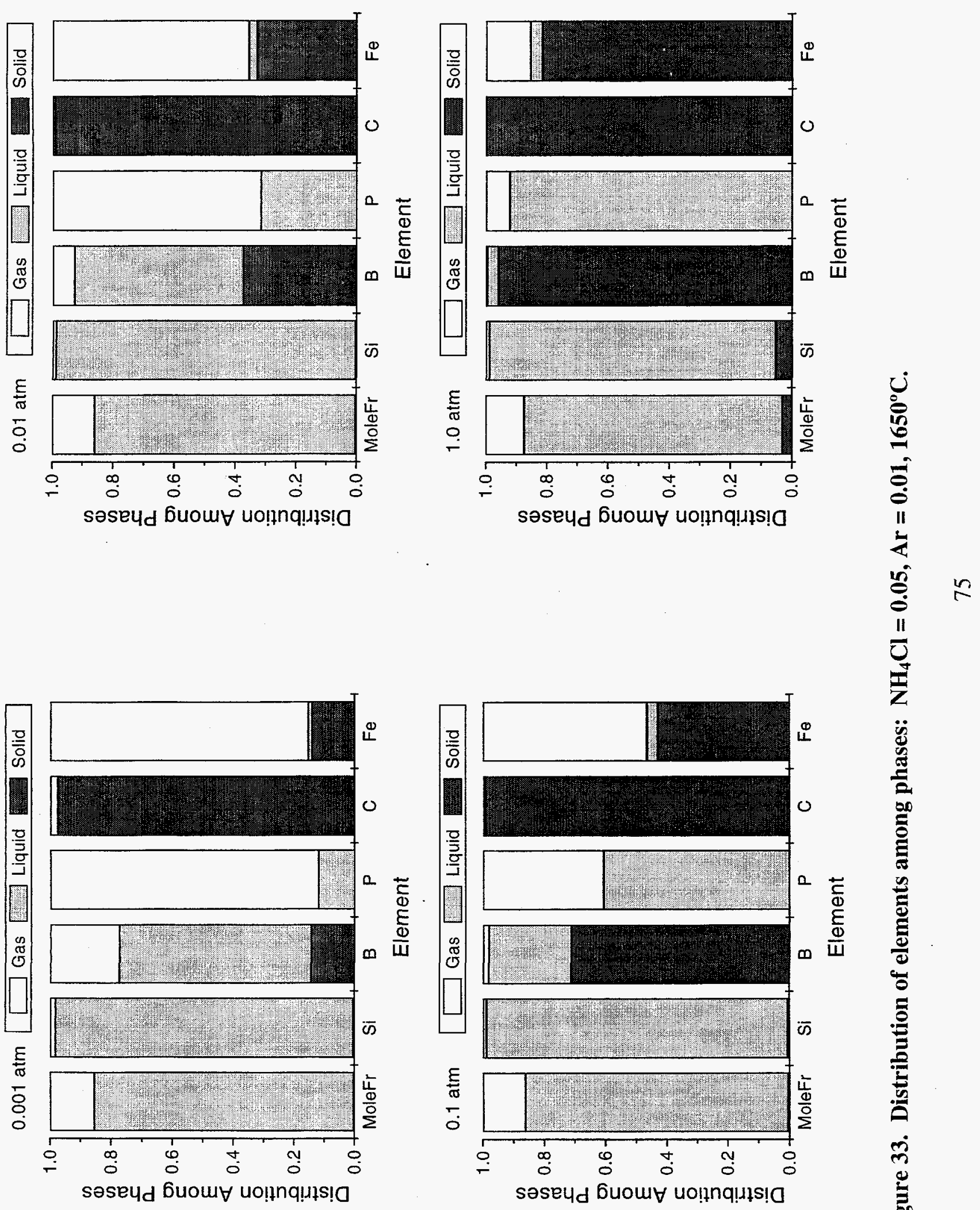

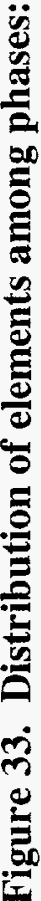




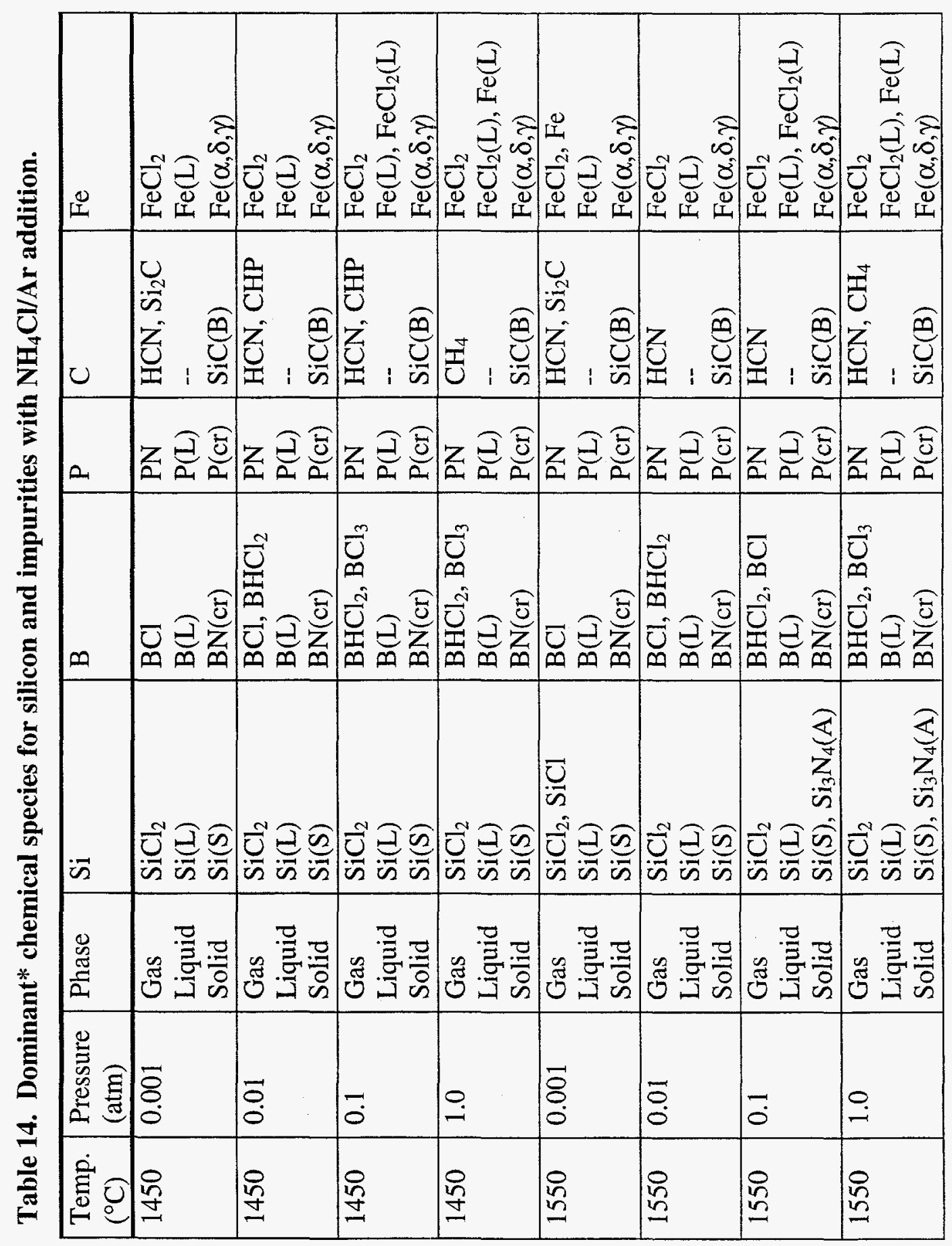




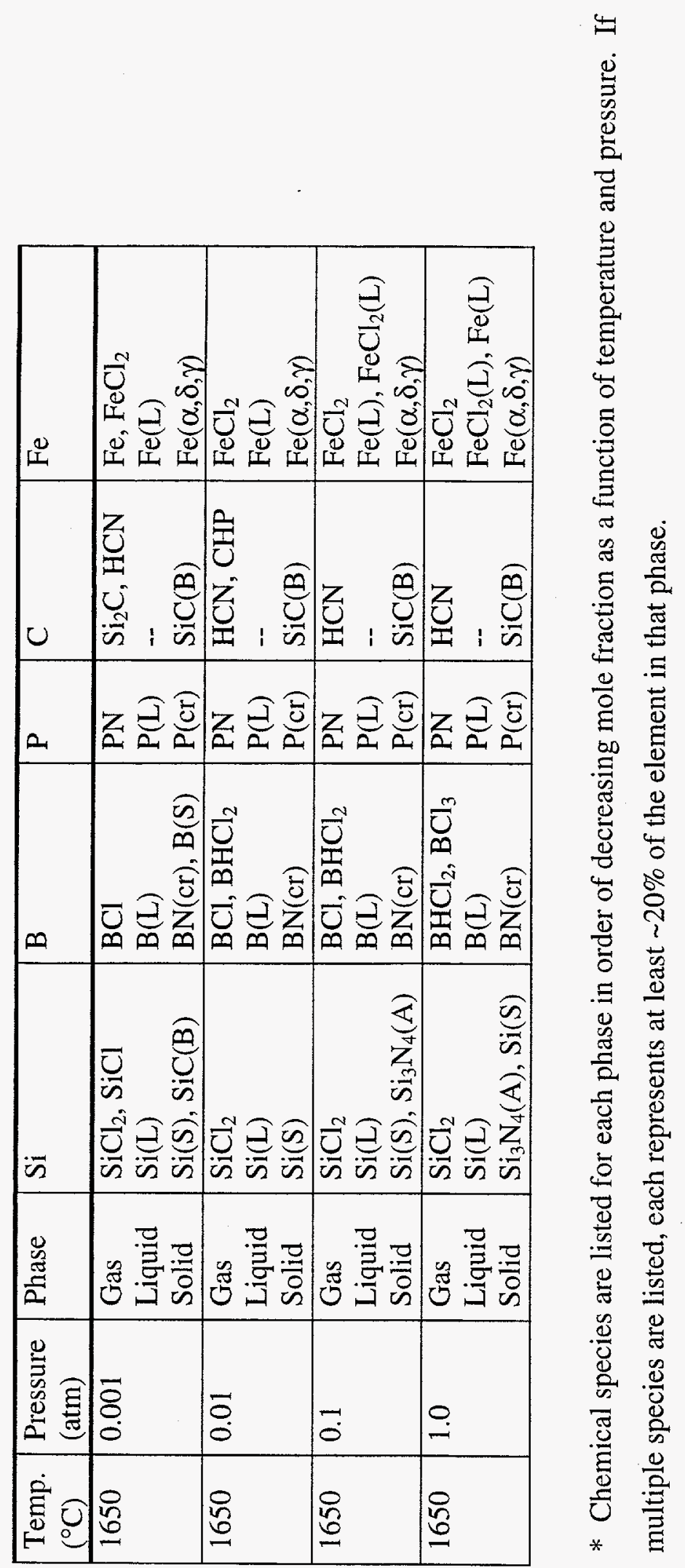




\section{Discussion}

The chemical equilibrium calculations suggest that the following treatments be investigated for the purification of polysilicon melts. There may well be kinetic limitations to these treatments, which are probably best investigated experimentally, rather than theoretically.

Carbon impurities could be removed by gas treatments containing oxygen or water via oxidation to $\mathrm{CO}$ at higher temperatures and lower pressures. Water treatments are less likely to have kinetic limitations than $\mathrm{O}_{2}$ treatments. If silicon carbide solid (density $~ 3.2$ ) can be separated from silicon liquid (density $\sim 2.5$ ), a non-oxidizing gas treatment might also work.

Phosphorus impurities can be removed by vaporization at lower pressures and higher temperatures in the absence of any gas treatment. In the presence of nitrogen, it could form a volatile species $\mathrm{PN}$, which then could be pumped away. Kinetically, $\mathrm{NH}_{3}$ is more likely to react than $\mathrm{N}_{2}$, although the equilibrium calculations indicate that gas treatments containing either could be effective at the lower pressures.

Boron impurities could be removed by reaction with water vapor to form $\mathrm{HBO}$ at moderate pressures and the higher temperatures, or by reaction with chlorine $\left(\mathrm{HCl}, \mathrm{Cl}_{2}\right.$ or $\left.\mathrm{SiCl}_{4}\right)$ to form boron chlorides $\left(\mathrm{BCl}, \mathrm{BHCl}_{2}\right.$ and $\left.\mathrm{BCl}_{3}\right)$ at lower pressures and higher temperatures. The calculations indicate that both of these treatments may be relatively inefficient, but may be workable. Solid boron nitride has a density of $\sim 2.25$, which is very close to that for silicon ( 2.52 liquid, 2.33 solid). But if it could be separated from the silicon, boron impurities could also be removed by reaction with $\mathrm{N}_{2}$ or $\mathrm{NH}_{3}$ to form $\mathrm{BN}(\mathrm{cr})$, which is favored at higher pressures and lower temperatures.

Iron impurities, like phosphorus, can apparently be removed to some degree by vaporization at lower pressures and higher temperatures in the absence of any gas treatment. Otherwise, treatment with chlorine $\left(\mathrm{HCl}, \mathrm{Cl}_{2}\right.$ or $\mathrm{SiCl}_{4}$ ), which leads to the formation of $\mathrm{FeCl}_{2}$, should allow the removal of iron impurities over a much wider range of pressures and temperatures. 
These gas treatments all involve some degree of silicon loss also. This places limits on the extent to which the gas treatment could be used to remove impurities before the loss of silicon becomes unacceptable. In the case of the oxidizing gases $\left(\mathrm{O}_{2}\right.$ and $\left.\mathrm{H}_{2} \mathrm{O}\right)$, most of the oxygen input into the system actually reacts with the silicon to form $\mathrm{SiO}$, which would wind up depositing on cold surfaces in the chamber or exhaust lines. In the case of the nitrogencontaining gases $\left(\mathrm{N}_{2}\right.$ and $\left.\mathrm{NH}_{3}\right)$, most of the input nitrogen also winds up reacting with the silicon to form solid silicon nitride at equilibrium. However, the reaction between silicon and $\mathrm{N}_{2}$ is generally considered to be relatively inefficient because of kinetic barriers. In the case of $\mathrm{HCl}$, $\mathrm{Cl}_{2}$ and $\mathrm{SiCl}_{4}$ treatment, silicon is lost by formation of volatile silicon chlorides. However, in some cases (higher pressure and lower temperature), silicon loss is decreased because not all the $\mathrm{HCl}$ and $\mathrm{SiCl}_{4}$ reacts away.

It is difficult to directly compare the results from these equilibrium calculations with the experimental literature. The calculations give results for a single "batch exposure", whereas the experiments are for a system in which gases are continuously flowed into the system and pumped out. In addition, the experimental papers generally do not specify the pressure of the system, which greatly affects the equilibrium calculations. The temperature, amount of chemical blowing and/or silicon sample size are also often unavailable. But qualitative comparisons are possible, and show a reasonable level of agreement.

Recently, Sakaguchi, et al. [6] reported the removal of phosphorus from electron-beam melted silicon in vacuum. Although the pressure and temperatures of their system is not given, this is consistent with the equilibrium calculations showing significant amounts of $\mathrm{P}_{2}$ at the lower pressures. These workers also reported the removal of boron by treatment with water vapor and an argon plasma torch, which is also consistent with the equilibrium results in section III. C. showing formation of volatile HBO with water addition. In these experiments, the plasma may have dissociated some of the water (the water vapor was injected separately from the argon for the plasma). This would serve to reduce kinetic limitations and possibly add heat to the system, but does not affect the comparisons with equilibrium calculations. 
The work by Khattak and Schmid [5] includes experiments on directional solidification at pressures of 0.2-0.3 Torr $\left(\sim 3 \times 10^{-4} \mathrm{~atm}\right)$, as well as argon blowing and slagging. They observed that directional solidification and argon blowing reduced phosphorus impurities, but that double directional solidification under vacuum and slagging reduced it more. This effect of vacuum and blowing is consistent with the equilibrium calculations showing the evaporation of phosphorus as $\mathrm{P}_{2}$. They also reported that iron levels were reduced by directional solidification under vacuum and by argon blowing. This is consistent with the equilibrium calculations that show the formation of gaseous Fe at the lower pressures and higher temperatures, and/or the removal of the iron by the directional solidification. Their best results overall were attained by a combination of moist argon blowing and slagging, which reduced all the impurities studied. This was the only treatment that reduced boron, which is consistent with the equilibrium calculations that show some removal of boron by water via the formation of $\mathrm{HBO}$. But this is not a very clear comparison because of combination of treatments.

An earlier study by this group [26] discusses the formation of silicon carbide particles in silicon melts that both accumulated at the bottom of the ingot and dispersed throughout it. They discuss removal of $\mathrm{SiC}$ by use of a silica slag, that would remove the $\mathrm{SiC}$ via formation of $\mathrm{CO}$ and/or $\mathrm{CO}_{2}$. This is consistent with the equilibrium calculations that show that the carbon impurities generally form $\mathrm{SiC}$ in the solid, but can be vaporized by $\mathrm{CO}$ formation in the presence of oxygen. However, as mentioned above, silicon loss by SiO formation can be considerable in oxygen-containing systems.

In 1975, Dosaj, et al. [3] carried out experiments on reactive gas blowing using $\mathrm{Cl}_{2}, \mathrm{O}_{2}$, or $\mathrm{Cl}_{2} / \mathrm{O}_{2}$ mixtures. The temperature was $\sim 1470^{\circ} \mathrm{C}$, but the pressure was not given. The flow rates and duration of blowing varied by factors of three for different experiments, but they are not specified. They reported that all three gases reduced boron impurities in metallurgical grade silicon by roughly a factor of 2 , but that phosphorus was not reduced. Iron was reduced by about a factor of 40 by $\mathrm{Cl}_{2}$ refinement, but by a factor of 3.5 by the $\mathrm{O}_{2}$ and $\mathrm{Cl}_{2} / \mathrm{O}_{2}$ treatments. Their observation that $P$ was not reduced is completely consistent with our results shown in Figure 16 for $\mathrm{Cl}_{2}$, Figure 1 for $\mathrm{O}_{2}$, and Figure 19 for $\mathrm{Cl}_{2} / \mathrm{O}_{2}$, if their pressure was 0.01 atm or higher. Their observation of moderate removal of boron is also consistent with the equilibrium 
calculations for $\mathrm{Cl}_{2}$ and $\mathrm{Cl}_{2} / \mathrm{O}_{2}$, but less so for $\mathrm{O}_{2}$ treatment, where the calculations would predict less efficient $\mathrm{B}$ removal that for the chlorine-containing gases, assuming comparable gas exposures. The observation that $\mathrm{Fe}$ is more efficiently removed than boron is consistent with the equilibrium calculations, as is the more efficient Fe removal in $\mathrm{Cl}_{2}$ than $\mathrm{O}_{2}$. But the equilibrium results suggest that the $\mathrm{Fe}$ removal rate with $\mathrm{Cl}_{2} / \mathrm{O}_{2}$ should be closer to that with $\mathrm{Cl}_{2}$, and that $\mathrm{O}_{2}$ should be quite inefficient.

In a later paper from the same group [4], however, they revised their conclusions. The final analysis of twenty experiments led to the result that reactive gas blowing using $\mathrm{Cl}_{2}$ or $\mathrm{Cl}_{2} / \mathrm{O}_{2}$ was ineffective for Fe removal, but exhibited $10 \% \mathrm{P}$ reduction and $40 \% \mathrm{~B}$ reduction. For $\mathrm{Fe}$, this is not entirely consistent with either their earlier report or the equilibrium calculations, but the B results remain consistent, and the minor degree of phosphorus removal could be caused by evaporation as $\mathrm{P}_{2}$ or experimental uncertainty.

In 1956, Theuerer [27] reported that treating liquid silicon with wet hydrogen led to the removal of boron, but not phosphorus. Although the pressure and temperature are not given, the experiments were probably done at a total pressure close to atmospheric and not much above the melting point of silicon, as only part of the silicon rods were molten at any given time. This is consistent with the equilibrium results in section III.C., which showed the formation of some volatile $\mathrm{HBO}$ at the higher pressures, but no volatile phosphorus oxides or hydroxides.

The papers by Dosaj, et al. [3] and by Dietl [28], also refer to earlier work on gas-blowing purification in the literature (primarily patents). These included the use of chlorine, $\mathrm{SiCl}_{4}$, and oxygen to reduce metal impurities, the use of water, air $\left(\mathrm{O}_{2}\right)$ and vacuum to reduce phosphorus, and the use of $\mathrm{CO}_{2}$ to reduce carbon impurities. Attempting to do comparisons between these reports and the equilibrium calculations is not warranted, given the low level of information available. But the calculations suggest that any $\mathrm{P}$ removal was probably due to evaporation rather than chemical reaction. In contrast, an equilibrium calculation done with added $\mathrm{CO}_{2}$ gave no indication of carbon removal via a reaction like $\mathrm{CO}_{2}+\mathrm{C}(\mathrm{S}) \rightarrow 2 \mathrm{CO}$. Instead, the system preferred to have the oxygen react with silicon to form $\mathrm{SiO}$, and the carbon react with silicon to 
form $\mathrm{SiC}(\mathrm{B})$. Hence the experimental observation of carbon removal by $\mathrm{CO}_{2}$ may be attributed to kinetic effects.

\section{Conclusions}

Chemical equilibrium calculations provide a useful tool for screening possible methods for removing $\mathrm{B}, \mathrm{P}, \mathrm{C}$ and $\mathrm{Fe}$ impurities from polysilicon melts by gas blowing. Examining the effects of a number of possible chemical additives $\left(\mathrm{O}_{2}\right.$, air, water wet air, $\mathrm{HCl}, \mathrm{NH}_{3}, \mathrm{NH}_{4} \mathrm{OH}$, and $\mathrm{NH}_{4} \mathrm{Cl}$ ) at 1450,1550 and $1650^{\circ} \mathrm{C}$, and total pressures of $0.001,0.01,0.1$, and $1.0 \mathrm{~atm}$, suggests the following:

1. Water vapor is a likely additive for removing carbon impurities as $\mathrm{CO}$, and boron impurities as $\mathrm{HBO}$, at lower total pressures and higher temperatures.

2. $\mathrm{NH}_{3}$ (and possibly $\mathrm{N}_{2}$ ) addition may provide a method of removing phosphorus impurities as $\mathrm{PN}$, although evaporation as $\mathrm{P}_{2}$ is known to work and would avoid silicon loss by $\mathrm{Si}_{3} \mathrm{~N}_{4}$ formation.

3. $\mathrm{HCl}$ or other chlorine-containing treatments may remove iron (and possibly other metals), along with some boron.

4. Combinations of additives (such as wet air or $\mathrm{Cl}_{2} / \mathrm{O}_{2}$ or $\mathrm{NH}_{4} \mathrm{Cl}$ ) offer the best prospects for removal of multiple impurities.

5. The extent of vaporization is quite dependent on total pressure as well as on temperature. Generally the lower total pressures are much more effective, which suggests that this is an important parameter to monitor/control in purification experiments.

6. The separation of solid reaction products (boron nitride, silicon carbide or silicon nitride) from liquid silicon, offers other treatment possibilities.

This study does not address chemical kinetic and transport limitations, which have been reported to be important [5] and are probably best investigated experimentally. But it should help guide and interpret the experiments, and hopefully reduce the number required. There are, of course, other considerations for designing a polysilicon purification method, including safety, energy and economic factors, but they await more experimental demonstrations of impurity removal. 


\section{References}

1. R. Brenneman, "Silicon Feedstock for Photovoltaics: Supply, Demand, and Availability", DynCorp Information \& Engineering Technology Report, April 1996.

2. G. Lutwack, "Flat-Plate Solar Array Project Final Report: Volume II - Silicon Material”, JPL Publication 86-31 (1986).

3. V.D. Dosaj, L.P. Hunt, and L.D. Crossman, "Single crystal silicon ingot pulled from chemically-upgraded metallurgical-grade silicon", $11^{\text {th }}$ IEEE Photo. Spec. Conf., 275-279 (1975).

4. L.P. Hunt, V. D. Dosaj, J. R. McCormick, and L. D. Crossman, "Production of solar-grade silicon from purified metallurgical silicon", $12^{\text {th }}$ IEEE Photo. Spec. Conf., 125-129 (1977).

5. C. P. Khattak, and F. Schmid, "Processing of MG Silicon for Photovoltaic Applications", in Proceedings of the Symposium on Materials and New Processing Technologies for Photovoltaics, J.A. Mick, V. K. Kapur and J. Dietl, Eds., Proceedings Volume 83-11, The Electrochemical Society, Pennington, NJ, 478-489 (1983).

6. Y. Sakaguchi, N. Yuge, N. Nakamura, H. Baba, K. Hanazawa, M. Abe and Y. Kato, "Purification of metallic grade silicon up to solar grade by NEDO melt purification process", $14^{\text {th }}$ Eur. PV Solar Energy Conf., 157-160 (1997).

7. J. M. Gee, P. Ho, J. Van Den Avyle, and J. Stepanek, "Some Thermochemical Calculations on the Purification of Silicon Melts", in 8th Workshop on Crystalline Silicon Solar Cell Materials and Processes, National Renewable Energy Laboratory, Golden, CO, NREL/CP520-25232 (1998).

8. C. P. Khattak, F. Schmid, D. B. Joyce, E. A. Smelik, and M. A. Wilkinson, "Production of Solar-Grade Silicon by Refining of Liquid Metallurgical-Grade Silicon", in NCPV Photovoltaic Program Review, Mowafak Al-Jassim, John P. Thornton, and James M. Gee, eds., AIP Conference Proceedings 462 (1998).

9. A. E. Lutz, R. M. Rupley and R. J. Kee, "EQUIL: A CHEMKIN Implementation of STANJAN for Computing Chemical Equilibria", Sandia National Laboratories, Livermore CA. 
10. R. J. Kee, F. M. Rupley, J. A. Miller, M. E. Coltrin, J. F. Grcar, E. Meeks, H. K. Moffat, A. E. Lutz, G. Dixon-Lewis, M. D. Smooke, J. Warnatz, G. H. Evans, R. S. Larson, R. E. Mitchell, L. R. Petzold, W. C. Reynolds, M. Caracotsios, W. E. Stewart, and P. Glarborg, "Chemkin Collection", Ver. 3.02, Reaction Design, Inc., (1997).

11. W. C. Reynolds, "STANJAN: Interactive Computer Programs for Chemical Equilibrium Analysis", Stanford University, Department of Mechanical Engineering Report, 1981.

12. R. J. Kee, R. M. Rupley, and J. A. Miller, "The Chemkin Thermodynamic Data Base", Sandia National Laboratories Report No. SAND87-8215B, March 1990.

13. P. Ho, M. E. Coltrin, J. S. Binkley, C. F. Melius, "A Theoretical Study of the Heats of Formation of $\mathrm{SiH}_{\mathrm{n}}, \mathrm{SiCl}_{\mathrm{n}}$, and $\mathrm{SiH}_{\mathrm{n}} \mathrm{Cl}_{\mathrm{m}}$ Compounds", J. Phys. Chem. 89, 4647 (1985); "A Theoretical Study of the Heats of Formation of $\mathrm{Si}_{2} \mathrm{H}_{\mathrm{n}}(\mathrm{n}=0-6)$ Compounds", J. Phys. Chem., 90, 3399 (1986).

14. M. D. Allendorf and C. F. Melius, "Theoretical Study of the Thermochemistry of Molecules in the Si-C-H System", J. Phys. Chem, 96, 428 (1992); "Theoretical Study of the Thermochemistry of Molecules in the Si-C-Cl-H System", J. Phys. Chem, 97, 720 (1993).

15. C. F. Melius and P. Ho, "Theoretical Study of the Thermochemistry of Molecules in the Si-N-H-F System", J. Phys. Chem, 95, 1410 (1991).

16. P. Ho and C. F. Melius, "Theoretical Study of the Thermochemistry of Molecules in the Si-O-H-C System", J. Phys. Chem, 99, 2166 (1995). M. D. Allendorf, C. F. Melius, P. Ho, and M. R. Zachariah, "Theoretical Study of the Thermochemistry of Molecules in the Si-O-H System", J. Phys. Chem, 99, 15285 (1995).

17. P. Ho, M. E. Colvin, C. F. Melius, "Theoretical Study of the Thermochemistry of Molecules in the Si-B-H-Cl System", J. Phys. Chem. A, 101, 9470 (1997).

18. M. D. Allendorf, C. F. Melius, "Thermochemistry of Molecules in the B-N-Cl-H System: $A b$ Initio Predictions Using the BAC-MP4 Method", J. Phys. Chem. A, 101, 2670 (1997).

19. M. W. Chase, Jr., C. A. Davies, J. R. Downey, Jr., D. J. Frurip, R. A. McDonald, A. N. Syverud, JANAF Thermochemical Tables, 3rd edition, J. Phys. Chem. Ref. Data, 14, Supp. $1,(1985)$. 
20. B. McBride, S. Gordon, and M. Reno, "CET/93PC, Chemical Equilibrium with Transport Properties", NASA Lewis Research Center, 1993. Available from COSMIC, the NASA Software Technology Transfer Center.

21. A. Burcat and B. McBride, "1994 Ideal Gas Thermodynamic Data for Combustion and AirPollution Use", TECHNION-Israel Institute of Technology Report TAE697, December 1993.

22. Private communication, John Noring, Lawrence Livermore National Laboratory.

23. http://www.ran.sandia.gov/chemkin/

24. V. I. Babushkin, G. M. Matveyev, and O. P. Mchedlou-Petrossyan, "Thermodynamics of Silicates", Springer-Verlag, New York (1985).

25. "Handbook of Chemistry and Physics, $52^{\text {nd }}$ edition", Robert C. Weast, Editor, The Chemical Rubber Company, Cleveland, 1971.

26. C. P. Khattak, F. Schmid, and L. P. Hunt, "Single Crystal Growth of Upgraded Metallurgical Silicon by HEM for Photovoltaic Applications", in Proceedings of the Symposia on Electronic and Optical Properties of Polycrystalline or Impure Semiconductors and Novel Silicon Growth Methods, K.V. Ravi and B. O'Mara, Eds., Proceedings Volume 80-5, The Electrochemical Society, Pennington, NJ, 223-232 (1980)

27. H. C. Theuerer, "Removal of Boron from Silicon by Hydrogen Water Vapor Treatment", $J$ Metals, 8, 1316-1319, (1956).

28. J. Dietl, "Metallurgical Ways of Silicon Meltstock Processing", Chapter 6 in Silicon Processing for Photovoltaics II, C. P. Khattak and K. V. Ravi, Eds., Elsevier Science, (1987). 
(Intentionally Left Blank) 


\section{APPENDIX: Example Output from EQUIL}

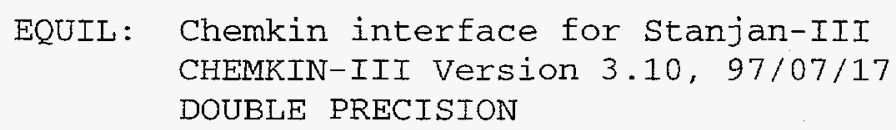

CKLIB : CHEMKIN-III GAS-PHASE CHEMICAL KINETICS LIBRARY,

DOUBLE PRECISION Vers. $5.1297 / 10 / 28$

Copyright 1995, Sandia Corporation.

The U.S. Government retains a limited license in this software.

SKLIB: CHEMKIN-III SURFACE KINETICS LIBRARY,

DOUBLE PRECISION Vers. 7.7 97/11/07

Copyright 1995, Sandia Corporation.

The U.S. Government retains a limited license in this software.

CKLIB: CHEMKIN-III GAS-PHASE CHEMICAL KINETICS LIBRARY, DOUUBLE PRECISION Vers. $5.1297 / 10 / 28$

Copyright 1995. Sandia Corporation.

The U.S. Government retains a limited license in this software.

SKLIB: CHEMKIN-III SURFACE KINETICS LIBRARY,

DOUBLE PRECISION Vers. $7.797 / 11 / 07$

Copyright 1995, Sandia Corporation.

The U.S. Government retains a limited license in this software.

KEYWORD INPUT

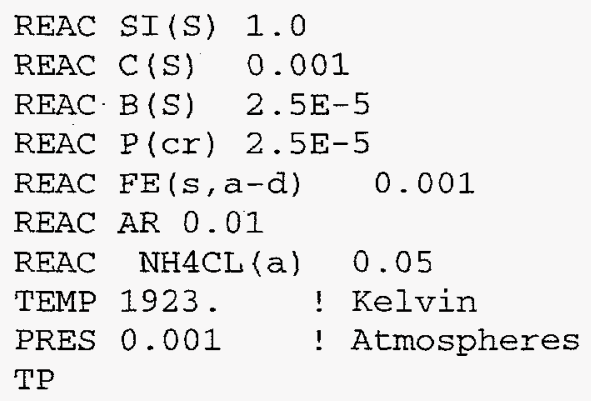

STANJAN: Version 3.95, September 1993

W. C. Reynolds, Stanford Univ.

MIXTURE: INITIAL STATE: EQUILIBRIUM STATE: 


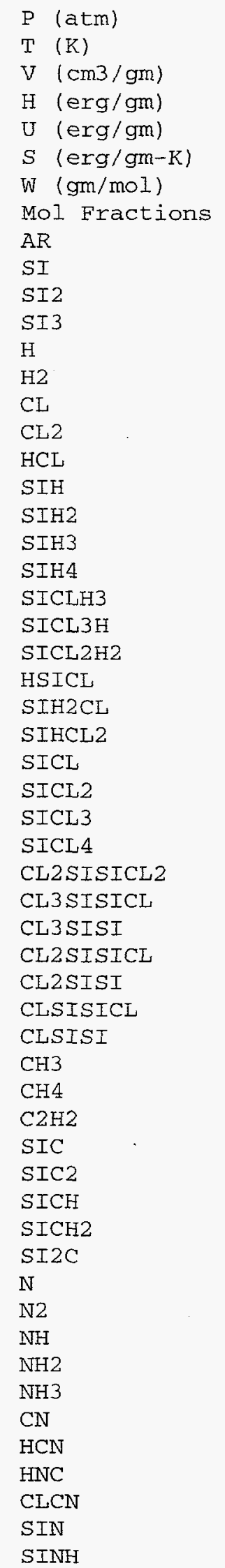

\begin{tabular}{|c|c|}
\hline $1.0000 E-03$ & $1.0000 \mathrm{E}-03$ \\
\hline 1. $9230 \mathrm{E}+03$ & 1. $9230 E+03$ \\
\hline $5.0530 E+04$ & $8.5146 E+05$ \\
\hline 1. $4531 \mathrm{E}+10$ & $-1.9355 \mathrm{E}+10$ \\
\hline 1. $4480 E+10$ & $-2.0218 \mathrm{E}+10$ \\
\hline $2.9313 E+07$ & $4.5434 E+07$ \\
\hline $2.9404 E+01$ & $2.7122 E+01$ \\
\hline $9.4158 \mathrm{E}-03$ & $8.6848 E-03$ \\
\hline $.0000 \mathrm{E}+00$ & $2.3776 E-03$ \\
\hline $.0000 E+00$ & $3.9577 \mathrm{E}-06$ \\
\hline $.0000 E+00$ & $4.8118 \mathrm{E}-06$ \\
\hline $.0000 E+00$ & $3.0826 \mathrm{E}-03$ \\
\hline $.0000 E+00$ & $7.3990 E-02$ \\
\hline $.0000 E+00$ & $7.0168 \mathrm{E}-04$ \\
\hline $.0000 E+00$ & $1.1585 E-08$ \\
\hline $.0000 \mathrm{E}+00$ & $2.2482 E-02$ \\
\hline $.0000 E+00$ & $1.7059 \mathrm{E}-05$ \\
\hline $.0000 E+00$ & $5.2741 E-07$ \\
\hline $.0000 \mathrm{E}+00$ & $1.1012 \mathrm{E}-09$ \\
\hline $.0000 \mathrm{E}+00$ & $4.2821 E-11$ \\
\hline $.0000 E+00$ & $1.1006 \mathrm{E}-09$ \\
\hline $.0000 E+00$ & $1.0624 E-07$ \\
\hline $.0000 E+00$ & 1. $6679 \mathrm{E}-08$ \\
\hline $.0000 E+00$ & $8.6713 E-05$ \\
\hline $.0000 \mathrm{E}+00$ & $1.9360 E-08$ \\
\hline $.0000 \mathrm{E}+00$ & $1.9462 \mathrm{E}-07$ \\
\hline $.0000 E+00$ & $5.1012 \mathrm{E}-03$ \\
\hline $.0000 E+00$ & $7.3139 E-03$ \\
\hline $.0000 E+00$ & $1.7579 E-06$ \\
\hline $.0000 E+00$ & $1.4906 \mathrm{E}-07$ \\
\hline $.0000 E+00$ & $7.8154 E-11$ \\
\hline $.0000 \mathrm{E}+00$ & $1.9559 \mathrm{E}-10$ \\
\hline $.0000 E+00$ & $5.4129 E-11$ \\
\hline $.0000 E+00$ & $1.8423 E-10$ \\
\hline $.0000 \mathrm{E}+00$ & $3.3800 E-09$ \\
\hline $.0000 E+00$ & $9.6549 \mathrm{E}-09$ \\
\hline $.0000 E+00$ & $5.7322 \mathrm{E}-08$ \\
\hline $.0000 E+00$ & $2.2532 \mathrm{E}-10$ \\
\hline $.0000 \mathrm{E}+00$ & $2.1901 E-10$ \\
\hline $.0000 E+00$ & $5.5132 E-09$ \\
\hline $.0000 E+00$ & $2.9014 E-10$ \\
\hline $.0000 \mathrm{E}+00$ & $1.0216 \mathrm{E}-08$ \\
\hline $.0000 E+00$ & $2.2411 E-09$ \\
\hline $.0000 E+00$ & $5.9922 \mathrm{E}-09$ \\
\hline $.0000 \mathrm{E}+00$ & 1. $4448 E-05$ \\
\hline $.0000 \mathrm{E}+00$ & $5.0224 E-10$ \\
\hline $.0000 E+00$ & $2.1674 \mathrm{E}-02$ \\
\hline $.0000 E+00$ & $9.1741 E-11$ \\
\hline $.0000 E+00$ & $5.6532 E-11$ \\
\hline $.0000 E+00$ & $4.8106 E-10$ \\
\hline $.0000 E+00$ & $5.8211 E-09$ \\
\hline $.0000 \mathrm{E}+00$ & $5.7394 \mathrm{E}-06$ \\
\hline $.0000 E+00$ & $4.5105 E-07$ \\
\hline $.0000 E+00$ & $8.1143 E-10$ \\
\hline $.0000 E+00$ & $1.1261 \Xi-08$ \\
\hline $.0000 \mathrm{E}+00$ & $3.7392 \mathrm{E}-05$ \\
\hline
\end{tabular}




\begin{tabular}{|c|c|c|}
\hline SINH2 & $.0000 E+00$ & $3.4836 \mathrm{E}-10$ \\
\hline SI2N & $.0000 E+00$ & $1.3836 E-05$ \\
\hline B & $.0000 E+00$ & $1.9017 E-09$ \\
\hline $\mathrm{BH}$ & $.0000 E+00$ & $3.0945 E-10$ \\
\hline $\mathrm{BH} 2$ & $.0000 E+00$ & $5.1370 E-11$ \\
\hline $\mathrm{BH} 3$ & $.0000 E+00$ & 1. $9334 E-10$ \\
\hline $\mathrm{BCL}$ & $.0000 E+00$ & $4.8228 E-06$ \\
\hline BCL2 & $.0000 \mathrm{E}+00$ & $8.6948 E-08$ \\
\hline $\mathrm{BCL} 3$ & $.0000 E+00$ & $7.3747 E-09$ \\
\hline HBCL & $.0000 E+00$ & 1. $0119 \mathrm{E}-09$ \\
\hline BHCL2 & $.0000 E+00$ & 1. $6642 E-08$ \\
\hline $\mathrm{BH} 2 \mathrm{CL}$ & $.0000 E+00$ & $2.6313 E-09$ \\
\hline $\mathrm{BNH}$ & $.0000 E+00$ & $1.7588 \mathrm{E}-11$ \\
\hline HBNH & $.0000 E+00$ & $6.4430 \mathrm{E}-12$ \\
\hline CLBNH & $.0000 E+00$ & $2.9119 E-10$ \\
\hline SIBH & $.0000 \mathrm{E}+00$ & $4.5439 \mathrm{E}-11$ \\
\hline SIBCL & $.0000 E+00$ & $7.0045 \mathrm{E}-10$ \\
\hline SIBCI2 & $.0000 E+00$ & $6.0418 \mathrm{E}-12$ \\
\hline $\mathrm{P}$ & $.0000 E+00$ & $1.1597 \mathrm{E}-06$ \\
\hline P2 & $.0000 \mathrm{E}+00$ & $1.7844 \mathrm{E}-07$ \\
\hline PCL & $.0000 E+00$ & $1.1427 \mathrm{E}-08$ \\
\hline $\mathrm{PH}$ & $.0000 \mathrm{E}+00$ & $4.6782 \mathrm{E}-08$ \\
\hline $\mathrm{PH} 2$ & $.0000 E+00$ & $6.3590 \mathrm{E}-10$ \\
\hline $\mathrm{PH} 3$ & $.0000 E+00$ & $1.1805 \mathrm{E}-11$ \\
\hline $\mathrm{CP}$ & $.0000 E+00$ & $6.1431 E-10$ \\
\hline $\mathrm{CHP}$ & $.0000 E+00$ & $5.5517 E-07$ \\
\hline PN & $.0000 E+00$ & $1.6985 E-05$ \\
\hline $\mathrm{FE}$ & $.0000 E+00$ & $5.2824 \mathrm{E}-04$ \\
\hline FECL & $.0000 E+00$ & $1.5511 \mathrm{E}-06$ \\
\hline FECL2 & $.0000 E+00$ & $2.0523 E-04$ \\
\hline FECL3 & $.0000 E+00$ & $8.8401 E-10$ \\
\hline$S I(L)$ & $.0000 E+00$ & $8.5089 E-01$ \\
\hline$B(I)$ & $.0000 E+00$ & $1.3656 \mathrm{E}-05$ \\
\hline $\mathrm{B} 203(\mathrm{~L})$ & $.0000 E+00$ & $.0000 \mathrm{E}+00$ \\
\hline$P(L)$ & $.0000 E+00$ & $2.5955 \mathrm{E}-06$ \\
\hline SIO2 (L) & $.0000 E+00$ & $.0000 E+00$ \\
\hline$F E(L)$ & $.0000 \mathrm{E}+00$ & $1.1398 \mathrm{E}-05$ \\
\hline FECL2 (L) & $.0000 E+00$ & $3.7962 E-08$ \\
\hline FECL3 (L) & $.0000 \mathrm{E}+00$ & $1.0274 \mathrm{E}-13$ \\
\hline $\mathrm{FEO}(L)$ & $.0000 E+00$ & $.0000 E+00$ \\
\hline$S I(S)$ & $9.4158 \mathrm{E}-01$ & $1.7540 E-03$ \\
\hline SIO2 (S) & $.0000 E+00$ & $.0000 E+00$ \\
\hline$B(S)$ & $2.3539 E-05$ & $1.0136 \mathrm{E}-06$ \\
\hline $\mathrm{B} 203(\mathrm{~S})$ & $.0000 E+00$ & $.0000 E+00$ \\
\hline$C(S)$ & $9.4158 E-04$ & $3.2872 E-05$ \\
\hline $\operatorname{SIC}(B)$ & $.0000 E+00$ & $8.1436 \mathrm{E}-04$ \\
\hline$P(C r)$ & $2.3539 E-05$ & $1.9867 E-12$ \\
\hline SI3N4 (A) & $.0000 E+00$ & $1.9091 \mathrm{E}-08$ \\
\hline $\mathrm{BN}(\mathrm{cr})$ & $.0000 E+00$ & $2.1011 E-06$ \\
\hline $\mathrm{NH} 4 \mathrm{CL}$ (a) & $4.7079 E-02$ & $6.1441 E-25$ \\
\hline NH4CL (b) & $.0000 E+00$ & $3.7009 E-26$ \\
\hline$F E(s, a-d)$ & $9.4158 E-04$ & $6.1373 E-05$ \\
\hline $\mathrm{FE}$ (s, gamma) & $.0000 E+00$ & $6.0641 E-05$ \\
\hline FECL2 $(s\rangle$ & $.0000 E+00$ & $5.5187 E-12$ \\
\hline FECL3 (s) & $.0000 E+00$ & $.0000 E+00$ \\
\hline FEO (s) & $.0000 E+00$ & $.0000 E+00$ \\
\hline $\mathrm{FE}(\mathrm{OH}) 2(\mathrm{~s})$ & $.0000 E+00$ & $.0000 E+00$ \\
\hline
\end{tabular}




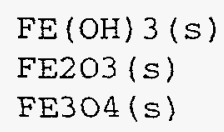

$.0000 E+00$

$.0000 E+00$

$.0000 E+00$

1. $0000 \mathrm{E}-02$

3. $9948 \mathrm{E}+01$

3. $9501 \mathrm{E}+06$

1. $0000 \mathrm{E}+00$

$.0000 E+00$

$.0000 E+00$

$.0000 \mathrm{E}+00$

$.0000 \mathrm{E}+00$

$.0000 \mathrm{E}+00$

$.0000 \mathrm{E}+00$

$.0000 E+00$

$.0000 \mathrm{E}+00$

$.0000 E+00$

$.0000 E+00$

$.0000 E+00$

$.0000 E+00$

$.0000 E+00$

$.0000 \mathrm{E}+00$

$.0000 \mathrm{E}+00$

$.0000 \mathrm{E}+00$

$.0000 \mathrm{E}+00$

$.0000 E+00$

$.0000 \mathrm{E}+00$

$.0000 E+00$

$.0000 E+00$

$.0000 E+00$

$.0000 \mathrm{E}+00$

$.0000 E+00$

$.0000 E+00$

$.0000 E+00$

$.0000 E+00$

$.0000 \mathrm{E}+00$

$.0000 \mathrm{E}+00$

$.0000 E+00$

$.0000 E+00$

$.0000 E+00$

$.0000 \mathrm{E}+00$

$.0000 E+00$

$.0000 E+00$

$.0000 E+00$

$.0000 E+00$

$.0000 E+00$

$.0000 \mathrm{E}+00$

$.0000 E+00$

$.0000 \mathrm{E}+00$

$.0000 \mathrm{E}+00$

$.0000 E+00$

$.0000 E+00$

$.0000 E+00$

$.0000 \mathrm{E}+00$

$.0000 \mathrm{E}+00$
$.0000 E+00$

$.0000 E+00$

$.0000 \mathrm{E}+00$

1. $6852 \mathrm{E}-01$

2. $1410 \mathrm{E}+01$

$7.3704 \mathrm{E}+06$

$5.9341 E-02$

1. $6245 \mathrm{E}-02$

2. $7042 E-05$

3. $2878 \mathrm{E}-05$

$2.1062 \mathrm{E}-02$

$5.0556 \mathrm{E}-01$

4. $7944 \mathrm{E}-03$

7. $9159 \mathrm{E}-08$

1. $5362 \mathrm{E}-01$

$1.1656 \mathrm{E}-04$

$3.6036 \mathrm{E}-06$

$7.5239 \mathrm{E}-09$

$2.9258 \mathrm{E}-10$

$7.5200 \mathrm{E}-09$

7. $2594 \mathrm{E}-07$

1.1397E-07

5. $9249 \mathrm{E}-04$

1. $3228 \mathrm{E}-07$

1. $3298 \mathrm{E}-06$

3. $4855 \mathrm{E}-02$

4. $9974 \mathrm{E}-02$

1. $2012 \mathrm{E}-05$

$1.0185 \mathrm{E}-06$

1. $0103 \mathrm{E}-12$

7. $4492 \mathrm{E}-14$

$1.0813 \mathrm{E}-13$

4. 2565E-15

$5.3400 E-10$

1. $3364 \mathrm{E}-09$

3. $6985 \mathrm{E}-10$

1. $2588 \mathrm{E}-09$

$2.3094 E-08$

$6.5969 E-08$

$3.9167 \mathrm{E}-07$

$.0000 E+00$

$.0000 \mathrm{E}+00$

$.0000 E+00$

$.0000 E+00$

$.0000 \mathrm{E}+00$

$1.5395 \mathrm{E}-09$

1. $4964 \mathrm{E}-09$

3. $7670 \mathrm{E}-08$

1. $9825 \mathrm{E}-09$

$6.9806 \mathrm{E}-08$

1. $5313 \mathrm{E}-08$

$4.0943 E-08$

$9.8722 \mathrm{E}-05$

7. $4175 E-14$ 


\begin{tabular}{|c|c|c|}
\hline CH3SICL & $.0000 \mathrm{E}+00$ & $6.3341 \mathrm{E}-12$ \\
\hline CL3SICH3 & $.0000 \mathrm{E}+00$ & $5.3727 \mathrm{E}-15$ \\
\hline H2CLSISICL 3 & $.0000 E+00$ & $9.3691 \mathrm{E}-15$ \\
\hline $\mathrm{HSI}=\mathrm{O}$ & $.0000 E+00$ & $.0000 E+00$ \\
\hline HOSI & $.0000 \mathrm{E}+00$ & $.0000 \mathrm{E}+00$ \\
\hline SIO & $.0000 E+00$ & $.0000 \mathrm{E}+00$ \\
\hline -SIOSIO- & $.0000 E+00$ & $.0000 E+00$ \\
\hline$N$ & $.0000 E+00$ & $3.4316 \mathrm{E}-09$ \\
\hline N2 & $.0000 E+00$ & $1.4809 E-01$ \\
\hline $\mathrm{NH}$ & $.0000 E+00$ & $6.2684 \mathrm{E}-10$ \\
\hline NH2 & $.0000 \mathrm{E}+00$ & $3.8627 \mathrm{E}-10$ \\
\hline NH3 & $.0000 E+00$ & $3.2870 \mathrm{E}-09$ \\
\hline NO & $.0000 \mathrm{E}+00$ & $.0000 E+00$ \\
\hline $\mathrm{CN}$ & $.0000 E+00$ & $3.9774 E-08$ \\
\hline $\mathrm{HCN}$ & $.0000 E+00$ & $3.9216 \mathrm{E}-05$ \\
\hline HNC & $.0000 E+00$ & $3.0819 E-06$ \\
\hline CLCN & $.0000 E+00$ & $5.5443 \mathrm{E}-09$ \\
\hline SIN & $.0000 \mathrm{E}+00$ & $7.6946 \mathrm{E}-08$ \\
\hline SINH & $.0000 \mathrm{E}+00$ & $2.5549 \mathrm{E}-04$ \\
\hline SINH2 & $.0000 \mathrm{E}+00$ & $2.3803 E-09$ \\
\hline SI2N & $.0000 \mathrm{E}+00$ & $9.4535 \mathrm{E}-05$ \\
\hline B & $.0000 E+00$ & $1.2994 \mathrm{E}-08$ \\
\hline $\mathrm{BO}$ & $.0000 \mathrm{E}+00$ & $.0000 \mathrm{E}+00$ \\
\hline $\mathrm{B} 2 \mathrm{O} 2$ & $.0000 E+00$ & $.0000 \mathrm{E}+00$ \\
\hline $\mathrm{BH}$ & $.0000 E+00$ & $2.1144 \mathrm{E}-09$ \\
\hline $\mathrm{HBO}$ & $.0000 E+00$ & $.0000 \mathrm{E}+00$ \\
\hline HOBO & $.0000 \mathrm{E}+00$ & $.0000 \mathrm{E}+00$ \\
\hline $\mathrm{BH} 2$ & $.0000 \mathrm{E}+00$ & $3.5100 \mathrm{E}-10$ \\
\hline $\mathrm{BH} 3$ & $.0000 E+00$ & $1.3210 \mathrm{E}-09$ \\
\hline $\mathrm{BH} 2 \mathrm{OH}$ & $.0000 \mathrm{E}+00$ & $.0000 \mathrm{E}+00$ \\
\hline BCL & $.0000 \mathrm{E}+00$ & $3.2953 \mathrm{E}-05$ \\
\hline BCL2 & $.0000 \mathrm{E}+00$ & $5.9409 \mathrm{E}-07$ \\
\hline BCL3 & $.0000 E+00$ & $5.0389 \mathrm{E}-08$ \\
\hline HBCL & $.0000 \mathrm{E}+00$ & $6.9142 \mathrm{E}-09$ \\
\hline BHCL2 & $.0000 E+00$ & $1.1371 \mathrm{E}-07$ \\
\hline $\mathrm{BH} 2 \mathrm{CL}$ & $.0000 E+00$ & $1.7979 \mathrm{E}-08$ \\
\hline BOCL & $.0000 \mathrm{E}+00$ & $.0000 \mathrm{E}+00$ \\
\hline $\mathrm{BN}$ & $.0000 E+00$ & $3.1358 \mathrm{E}-14$ \\
\hline $\mathrm{BNH}$ & $.0000 E+00$ & $1.2018 \mathrm{E}-10$ \\
\hline BNH2 & $.0000 E+00$ & $6.6231 \mathrm{E}-13$ \\
\hline $\mathrm{B}(\mathrm{NH} 2) 2$ & $.0000 E+00$ & $2.6083 \mathrm{E}-22$ \\
\hline $\mathrm{B}(\mathrm{NH} 2) 3$ & $.0000 E+00$ & 1. $1405 \mathrm{E}-27$ \\
\hline B3N3H6 & $.0000 E+00$ & $3.1814 \mathrm{E}-32$ \\
\hline $\mathrm{H} 2 \mathrm{BN}$ & $.0000 E+00$ & $1.4245 \mathrm{E}-18$ \\
\hline $\mathrm{H} 2 \mathrm{BNH}$ & $.0000 \mathrm{E}+00$ & $8.0961 \mathrm{E}-16$ \\
\hline $\mathrm{H} 2 \mathrm{BNH} 2$ & $.0000 E+00$ & $6.0411 \mathrm{E}-15$ \\
\hline H3 BNH3 & $.0000 E+00$ & $5.4416 E-25$ \\
\hline $\mathrm{HB}(\mathrm{NH} 2) 2$ & $.0000 \mathrm{E}+00$ & $1.6003 \mathrm{E}-21$ \\
\hline $\mathrm{HBN}$ & $.0000 E+00$ & $1.7967 \mathrm{E}-13$ \\
\hline HBNH & $.0000 E+00$ & $4.4024 \mathrm{E}-11$ \\
\hline HBNH2 & $.0000 E+00$ & $1.9387 \mathrm{E}-15$ \\
\hline CLBNH & $.0000 \mathrm{E}+00$ & $1.9896 \mathrm{E}-09$ \\
\hline $\mathrm{BCL} 2 \mathrm{NH} 2$ & $.0000 \mathrm{E}+00$ & $8.3678 \mathrm{E}-14$ \\
\hline SIBH & $.0000 \mathrm{E}+00$ & $3.1047 \mathrm{E}-10$ \\
\hline SIBCL & $.0000 E+00$ & $4.7860 E-09$ \\
\hline SIBCL2 & $.0000 \mathrm{E}+00$ & $4.1282 \mathrm{E}-11$ \\
\hline $\mathrm{P}$ & $.0000 E+00$ & $7.9238 \mathrm{E}-06$ \\
\hline
\end{tabular}




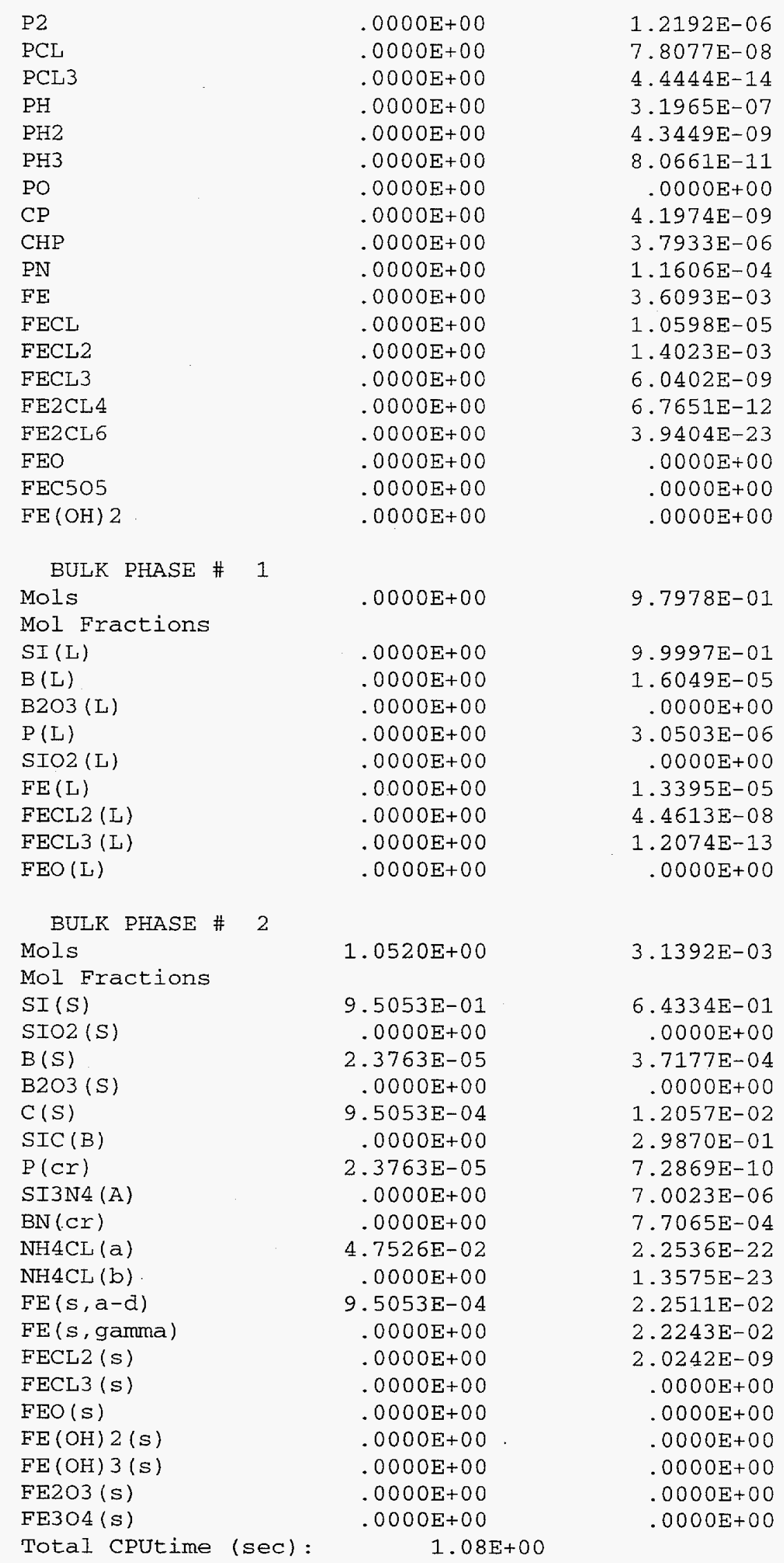




\section{DISTRIBUTION}

Dr. Chandra Khattak

Crystal Systems, Inc.

27 Congress Street

Salem, MA 01970

Dr. Bob Hall

AstroPower

Solar Park

Newark, DE 19716-2000

Dr. James Rand

AstroPower

Solar Park

Newark, DE 19716-2000

Dr. Frank Zanner

80 Skyline Drive

Sandia Park, NM 87047

Dr. Richard King

U. S. Department of Energy

Forrestal Bldg., EE-11

1000 Independence Ave., SW

Washington, D.C. 20585

Dr. Jeffrey Mazer

U. S. Department of Energy

Forrestal Bldg., EE-11

1000 Independence Ave., SW

Washington, D.C. 20585

Mr. Ted Ciszek

NREL

1617 Cole Blvd.

Golden, CO 80401-3393

Dr. Tihu Wang

NREL

1617 Cole Blvd.

Golden, CO 80401-3393
Dr. Bhushan Sopori

NREL

1617 Cole Blvd.

Golden, CO 80401-3393

Dr. Simon Tsuo

NREL

1617 Cole Blvd.

Golden, CO $80401-3393$

Dr. Mohan Narayanan

Solarex Corporation

630 Solarex Court

Frederick, MD 21701

Dr. John Wohlgemuth

Solarex Corporation

630 Solarex Court

Frederick, MD 21701

Ed Henderson

Matrix Solar

P. O. Box 14740

Albuquerque, NM 87191-4740

Ron Gehringer

SiNaF Products, Inc.

5600 Gibson Blvd. SE, Bldg. 153

Albuquerque, NM 87108

Dr. Jack Hanoka

Evergreen Solar, Inc.

211 Second Avenue

Waltham, MA 02154

Dr. Andrew Gabor

Evergreen Solar, Inc.

211 Second Avenue

Waltham, MA 02154 
Dr. Juris Kalejs

ASE Americas, Inc.

Four Suburban Park

Billerica, MA 01821-3980

Dr. Michael Kardauskas

ASE Americas, Inc.

Four Suburban Park

Billerica, MA 01821-3980

Dr. Mark Rosenblum

ASE Americas, Inc.

Four Suburban Park

Billerica, MA 01821-3980

Ms. Theresa Jester

Siemens Solar Industries

P. O. Box 6032

Camarillo, CA 93011

Dr. Dan Meier

Ebara Solar, Inc.

811 Rt. 51 South

Large, PA 15025
Prof. Ajeet Rohatgi

Georgia Institute of Technology

777 Atlantic Drive

School of Electrical Engineering

Atlanta, GA 30332

$100601 \quad$ Pauline Ho, 01126

10601 Jeff Tsao, 01126

100752 James Gee, 06219

10752 Dan Aiken, 06219

10752 David King, 06219

10752 Doug Ruby, 06219

10753 Christopher Cameron, 06218

11134 James Van den Ayvle, 01846

11134 James Stepanek, 01846

11203 John M. Taylor, 05335

11349 William F. Hammetter, 01846

19018 Central Tech. Files, 08940-2

20899 Technical Library, 04916

10619 Review \& Approval Desk, 00111

For DOE/OSTI 